\title{
SST Sample Characterization Analysis of Archive Samples 102-C, 105-C, and 106-C
}
D. L. Thomas
R. T. Steele
F. T. Hara
R. W. Stromatt
J. H. Kaye
M. W. Urie

February 1991

Work supported by

the U.S. Department of Energy

under Contract DE-AC06-76RLO 1830

Pacific Northwest Laboratory

Operated for the U.S. Department of Energy

by Battelle Memorial Institute 


\title{
DISCLAIMER
}

This report was prepared as an account of work sponsi)red by an agency of the United States Government. Neither the United States Government nor any agency thereof, nor Battelie Memorial Institute, nor any of their employees, makes any warranty, expressed or implied, or assumes any legal liability or responsibility for the accuracy, completeness, or usefulness of any information, apparatus, product, or process disclosed, or represents that its use would not infringe privately owned rights. Reference herein to any specific commercial product, process, or service by trade name, trademark, manufacturer, or otherwise does not necessarily constitute or imply its endorsement, recommendation, of favoring by the United States Government or any agency thereof, or Battelle Memorial Institute. The views and opinions of authors expressed herein do not necessarily state or reflect those of the United States Government or any agency thereof.

\author{
PACIFIC NORTHWEST LABORATORY \\ operated by \\ BATTELLE MEMORIAL INSTITUITE \\ for the \\ UNITED STATES DEPARTMENT OF IENERGY \\ under Contract DE-AC06-76RLO 1830
}

\author{
Printed in the United States of America
}

Available to DOE and DOE contractorg frum the

Office of Scientific and Technical Information, P.O. Box 62. Oak Ridge, TN 37831; prices available from (615) 576-8401. FTS 626-8401.

Available to the public from the National Technical Information Service, U.S. Department of Commerce, 5285 Port Royal Rd., Springfield, vA 22161. 
PNL-7258 Rev 1

D. L. Thomas

J. H. Kaye

R. T. Steele

R. W. Stromatt

M. W. Urie

\section{February 1991}

Work supported by the U.S. Department of Energy under Contract DE-ACO6-76RLO 1830

Pacific Northwest Laboratory

Richland, Washington 99352

(a) Currently a private consultant 
$-$ 


\section{EXECUTIVE SUMMARY}

A major effort at Hanford over the next few years will be to sample and analyze wastes contained in 149 single-she11 tanks (SSTs). In preparation for this effort, selected analyses were performed on four archived samples to compare analytical methods and to detemine applicability of these methods to the waste samples. The analyses, performed by the Pacific Northwest Laboratory (PNL) (a), used a variety of analytical methods including both PNL technical procedures and adaptations of U.S. Environmental Protection Agency (EPA) technical procedures.

Although data are reported for analyses of actual waste tank samples, the data do not serve to characterize any waste in Hanford tanks. Since this investigation was intended only as a comparison of analytical methods, and the samples are from an archive repository, the results are preliminary in nature. The numerical values are to be evaluated with appropriate respect for the limited usefulness of small amounts of data generated through an analytical development process using only four samples.

The analysis of the archived SST waste material provides three important types of data for use in planning later phases of sample analysis. The data serve as input for 1) establishing analysis procedures and methods for waste samples, 2) evaluating the impact that using a silicon-based lubricant and normal paraffin hydrocarbon (NPH) in field sampling has on extracting inorganics or radionuclides from the SST sample, and 3) identifying trends in amounts of occupational radiation exposure expected from performing the various analysis procedures.

Inorganic analysis work was undertaken to detemine 1) the applicability of various analytical methods to the test samples, 2) if mercury can be determined by cold vapor atomic absorption (CVAA), 3) if the inductively-coupled plasma (ICP) spectrometer has sufficient sensitivity for the analysis of EP Toxicity metal ions (excluding mercury), and 4) which of the 22 EPA pollutant metal ions can be determined by ICP analysis. Poor reproducibility was obtained

(a) Operated for the U. S. Department of Energy by Battelle Memorial Institute under contract DE-ACO6-76RLO 1830. 
with water leach and EP Toxicity methods, but acid digestion gave good reproducibility. Some of the procedures were changed if, due to interference by other elements, the methods did not provide the levels of sensitivity, accuracy, or precision usually required for EPA work. When appropriate, other methods are suggested for trial as alternatives. Some procedural adjustments were required for mercury analysis by CVAA. Problems areas identified are ICP sensitivities and ICP spectral corrections when analyzing for minor constituents (e.g., Ag, As, Pb, Se, Tl, and V); if elements of this class are critically important, they should be determined by alternative methods.

Organics analysis investigations were conducted to determine if the EPA semivolatile organic method can be employed on SST samples. Silicone-based lubricants and NPH from the sampling process impact the semivolatile analysis; however, with slight modification the procedure of EPA SOW 288 can be used. The results show that the gas chromatograph/mass spectrometer (GC/MS) is vulnerable to fouling and overload and that a combination of dilution and acidification is required to provide acceptable results. Work also included evaluation of 1) screening procedures for gas chromatography (GC) and total organic carbon (TOC), 2) extraction procedures and related problens, and 3) surrogate spiking to test extraction efficiencies and matrix effects.

Development work was performed to gather information relevant to the potential use of radionuclide ratioing and parent-daughter relationships for the estimation of radionuclides within samples. The radionuclides expected in the SST tank waste samples were measured to determine the level of accuracy and precision that can be expected. These data reveal that some level of procedure development is needed for a large number of the radionuclides analyses.

Tests were conducted to determine whether the NPH from the field sampling process extracted significant quantities of the inorganics or radionuclides from the SST samples. No such extraction was observed; however, the NPH does have a significant adverse effect on organic analysis, and alternatives to NPH should be investigated. Effects of silicon-based lubricant were not experimentally evaluated apart from sample analysis. 
Trends in expected occupational exposure were obtained by measuring the radiation level of samples and having the analysts record estimates of the contact time with the samples. Data revealed that the analysts received no significant exposure and that, as expected, the potential dose is directly proportional to the sample size and handling times. 


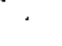

, ' 


\section{CONTENTS}

EXECUTIVE SUMMARY .............................. i ...

GLOSSARY . . . . . . . . . . . . . . . . . . . xi

1.0 INTRODUCTION . . . . . . . . . . . . . . . . . . . . . . . . . .

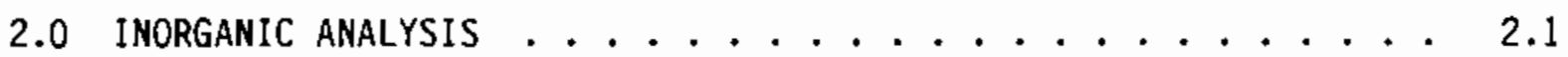

2.1 TEST METHODS, RESULTS, AND DISCUSSION . . . . . . . 2.2

2.1.1 Sample Preparation . . . . . . . . . . . 2.2

2.1.2 Percent Solids Determination . . . . . . . . 2.2

2.1 .3 Water Leach . . . . . . . . . . . . . 2.2

2.1.4 EP Toxicity ................ 2.3

2.1.5 Acid Digestion ............... 2.4

2.1.6 Fusion: ICP Analysis ............. 2.5

2.1.7 Comparison of Water Leach, EP Toxicity, Acid Digestion, and Total Fusion ICP

Analysis Results ............ 2.6

2.1.8 Mercury Analysis by Cold Vapor Atomic
Absorption (CVAA) . . . . . . . . . . . 2.7

2.1.9 Total Cyanide............... . . 2.7

2.2 PROBLEM AREAS AND CORRECTIVE ACTIONS . . . . . . . . 2.7

2.2.1 ICP Spectral Corrections . . . . . . . . . 2.7

2.2.2 Poor Reproducibility from Water Leach and

2.2.3 Modification to CVAA Method .......... 2.8

2.3 CONCLUSIONS RELATED TO TEST PLAN OBJECTIVES 2.9

2.3.1 To Determine if There Are Problens with Employing the Various Analytical Methods on the Test Samples............ 2.9 
2.3.2 To Determine if the ICP Has Sufficient Sensitivity for Analys is of the EP Toxicity Metal Ions (excluding $\mathrm{Hg}$ ) . . . . . . . . 2.9

2.3.3 To Determine Which of the 22 EPA Pollutant Metal Ions Can Be Determined by ICP Analysis . . . 2.10

2.3.4 To Determine if Mercury Can Be Determined by the CVAA Method............... 2.10

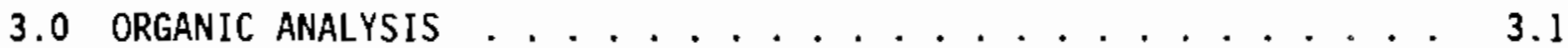

3.1 TEST METHODS, RESULTS, AND DISCUSSION . . . . . . . 3.1

3.1.1 Experimental ................ 3.1

3.1.2 Surrogate and Matrix Spike Test . . . . . . . . . . 3.2

3.1.3 Target Compounds . . . . . . . . . . . . 3.2

3.1.4 Tentatively Identified Compounds . . . . . . 3.3

3.2 PROBLEM AREAS AND CORRECTIVE ACTIONS ........... 3.3

3.2.1 Presence of NPH and Silicone-Based Lubricant

Products. . . . . . . . . . . . . . 3.3

3.2.2 Extraction. . . . . . . . . . . . . . . 3.4

3.2.3 Sample Concentration and Composition . . . . . . . . 3.4

3.3 CONCLUSIONS RELATED TD TEST PLAN OBJECTIVES 3.6

3.3.1 To Determine Whether the EPA Semivolatile

Organic Method Can Be Employed on SST Samples . . . . 3.6

3.4 DESCRIPTION OF DATA SHEETS . . . . . . . . . . . . . 3.6

4.0 RADIONUCLIDE ANALYSIS . . . . . . . . . . . . . . . 4.1

4.1 TEST METHODS, RESULTS, AND DISCUSSION . . . . . . . 4.1

4.1.1 Sample Fusion................. . 4.1

4.1.2 Summary of Radiochemical Measurements . . . . . . 4.1

4.2 PROBLEM AREAS AND CORRECTIVE ACTIONS . . . . . . . . 4.2

4.2.1 Crucible Contamination ............. 4.2

4.2.2 Cesium-137 Activity Level . . . . . . . . . . 4.3 
4.2.3 Procedures for Specific Radionuclides ....... 4.3

4.3 CONCLUS IONS RELATED TO TEST PLAN OBJECTIVES $\ldots \ldots . \ldots$

\subsubsection{To Gather Information Relevant to the Potential Use of Radionuclide Ratioing and Parent-Daughter Relationships for the Estimation of Radionuclides within Sample .............. 4.7}

5.0 NORMAL PARAfFin HYDROCARBON STUdIES ........... 5.1

5.1 TEST METHODS, RESULTS, AND DISCUSSION . . . . . . . 5.1

5.1 .1 Experimental .................... 5.1

5.1.2 ICP Inorganic Constituent Solubility Results . . . 5.1

5.1.3 Radionuclide Solubility Results ........ 5.2

5.2 CONCLUSiONS Related to test Plan OBjectives. . . . . . 5.2

5.2.1 To Determine the Solubility of Inorganic
and Radiochemical Ions in NPH ....... 5.2

6.0 RADIOLOGICAL EXPOSURE STUDY . . . . . . . . . . 6.1

6.1 TEST METHOOS, RESULTS, AND DISCUSSION . . . . . . 6.1

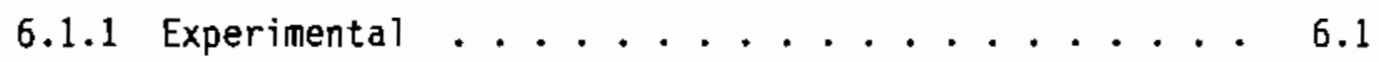

6.1 .2 Exposure Sunnary .............. 6.1

6.2 CONCLUSions Related to test Plan OBJeCtives. . . . . . . 6.1

6.2.1 To Gather Information on the Radiological

Exposure and Time Durations Required in

Utilizing the Various Methods .......... 6.1

APPENDIX - TEST PLAN FOR ANALYSIS OF ARCHIVE SAMPLES OF SINGLE-SHELL TANK SAMPLES PROVIDED BY WESTINGHOUSE HANFORD COMPANY 


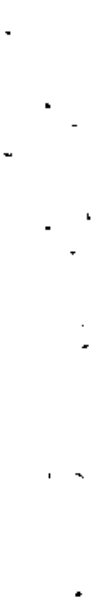




\section{FIGURES}

3.1 Target Compounds, Blank Sample ................ 3.8

3.2 Target Compounds, Acidified Sample . . . . . . . . 3.10

3.3 Target Compounds, Unacidified Sample . . . . . . . 3.12

3.4 Tentatively Identified Compounds, Blank Sample ...... 3.14

3.5 Tentatively Identified Compounds, Acidified Sample . . . . 3.15

3.6 Tentatively Identified Compounds, Unacidified Sample . . . 3.16

\section{TABLES}

2.1 SST Sample 102-C Water Leach Measurements by ICP Analysis . . . 2.11

2.2 Uranium Correction Factors for Elements Measured

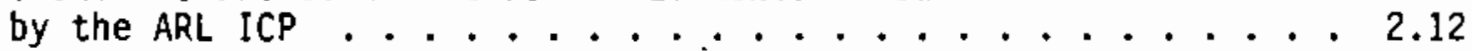

2.3 Anion Analysis of Water Leach from SST Sample 102-C . . . . 2.13

2.4 EP Toxicity Measurements and Spike Recovery Study by ICP Analysis for SST Sample 102-C . . . . . . . . 2.13

2.5 Results of $5 X$ Dilution on EP Toxicity Measurements by ICP for SST Sample 102-C ................... 2.14

2.6 EP Toxicity Results by ICP Analys is in Units of $\mathrm{mg} / \mathrm{kg}$

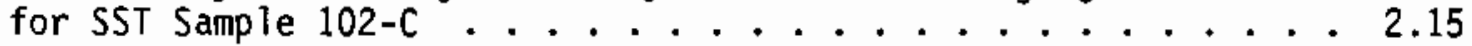

2.7 Acid Digestion Measurements and Spike Recovery Study by ICP for SST Sample 102-C (inctuding GFAA Results) . . . . 2.16

2.8 ICP Serial Dilution Results of Acid Digestion of SST Sample 102-C . . . . . . . . . 2.17

2.9 Comparison of $\mathrm{KOH}$ and $\mathrm{Na}_{2} \mathrm{O}_{2}$ Fusion of ICP Analys is for SST Sample 102-C . . . . . . . . . . . 2.18

2.10 Sum of Acid Digestion and Fusion of Acid Insoluble Residue for SST Sample 102-C ............. 2.19 
2.11 Comparison of ICP KOH Fusion Results for SST Samples 102-C, 105-C, and I06-C.............. 2.20

2.12 Direct Comparison of the Test Methods by IĈP for SST Sample 102-C . . . . . . . . . . . . . 2.21

2.13 Summary of EP Toxicity Metal Ions by ICP . . . . . . . . . 2.22

2.14 Summary of EPA Pollutant Metal Ions by ICP . . . . . . . . 2.22

4.1 Total Alpha, Total Beta, and GEA Results for SST Samples 105-C and 106-C................ 4.7

4.2 Radiochemical Measurements and Tracer YieIds for SST Samples 105-C and 106-C . . . . . . . . . . 4.8

4.3 Uranium Isotopic Analyses on SST Samples 105-C and 106-C . . . . . . . . . . . . 4.9

5.1 ICP and IC Measurements for NPH Equilibrated with Composite of SST Samples 106-C and 102-AX ........ 5.3

5.2 Total Alpha, Total Beta, and GEA Results on NPH Equilibrated with Composite of SST Samples 106-C and 102-AX . . . . . . 5.4

6.1 Exposure Data Sumnary for Radiochemical Separations . . . . . . 6.2

6.2 Exposure Data Surmary for Inorganic Analyses . . . . . . . 6.3 


\section{GLOSSARY}

AEA - Alpha energy analysis

ARL - Applied Research Laboratory

CLP - Contract Laboratory Program

CRQL - Contract required quantitation limits (specified by EPA)

CVAA - Cold vapor atomic absorption

DIW - Deionized water

EPA - U.S. Environmental Protection Agency

EP Toxicity - An extraction procedure for toxic metals specified by EPA, also called EP Tox

GC - Gas chromatograph (or gas chromatography)

GEA - Gamma energy analys is

GFAA - Graphite furnace atomic absorption

IC - Ion chromatograph (or ion chromatography)

ICP - Inductively coupled plasma spectroscopy

MS - Mass spectroscopy (or mass spectrometer)

NPH - Normal paraffin hydrocarbon

PNL - Pacific Northwest Laboratory

RPD - Relative percent differences

SOW 288 - Version of EPA CLP organic procedures for CERCLA work, issued in February, 1988

SOW 787 - Version of EPA CLP inorganic procedures for CERCLA work, issued in July, 1987

SW 846 - EPA procedures for RCRA work

SST - Single-shell tank in which Hanford's radioactive waste is stored

TIC - Total inorganic carbon

TOC - Total organic carbon

WHC - Westinghouse Hanford Company 



\subsection{INTROOUCTION}

A major effort at Hanford over the next few years will be to sample and analyze wastes contained in 149 single-shell tanks (SSTs). In preparation for this effort, selected analyses were performed on four archived samples to compare analytical methods and to determine applicability of these methods to the waste samples.

The analyses used a variety of analytical methods including both Pacific Northwest Laboratory (PNL) technical procedures and adaptations of U.S. Environmental Protection Agency (EPA) technical procedures. Quality control included use of blanks and spikes, but did not include all EPA requirements such as use of control charts. Since the objective was evaluation and comparison of methods rather than determining precise values, this degree of quality control was considered to be sufficient.

This report describes and presents results of the preliminary trial analyses of archived SST samples by the Chemical Measurements Laboratory section of PNL. The archived samples were wastes from waste tanks 102-C, $105-C$, and 106-C, and a composite of supernatant liquid from waste tanks 102$A X$ and 106-C. As stated in the Test Plan for Analysis of Archive Samples of Single-Shell Tank Samples Provided by Westinghouse Hanford Company (Project 13924), the test scope and objectives are as follows:

- to determine if there are problems with employing the various analytical methods on the test samples

- to determine if the ICP has sufficient sensitivity for the analysis of EP Toxicity metal ions (excluding mercury, which will be analyzed by the cold vapor method)

- to detemine which of the 22 EPA pollutant metal ions can be determined by ICP analys is

- to determine if mercury can be detemined by the cold vapor method

- to determine whether the EPA semivolatile organic method can be employed on SST samples

- to determine solubility of inorganic and radiochemical ions in NPH

- to gather information on the radiological exposure and time durations required in utilizing the various methods 
- to gather information relevant to the potential use of radionuclide ratioing and parent-daughter relationships for the estimation of radionuclides within samples.

The following tasks were performed: 1) organic and inorganic analyses were performed on sample 102-C, 2) radiochemical analyses and ICP inorganic analyses were performed on samples $105-C$ and $106-C$, and 3 ) the normal paraffin hydrocarbon (NPH) radiochemical and inorganic measurements were performed on a combined sample of 106-C and 102-AX supernatant (not 105-C and 102-AX as specified in the Test Plan). The Test Plan is included as an Appendix.

The analysis of the SST archive samples involved three types of measurements: inorganic analysis, organic analysis, and radiochemical analysis. This report is divided into five sections; the first three separately discuss each of the measurement categories, a fourth section discusses the NPH study, and the final section addresses radiological exposure measurements. The objectives for each measurement category, which are bulleted on page 1 of the Test Plan, are addressed at the end of each section.

The tables and figures for Sections 2.0 through 6.0 are at the end of each section. 


\subsection{INORGANIC ANALYSIS}

The sample preparation and percent solids determinations are included in this section, as well as a discussion of the results from the following test methods: water leach, EP Toxicity, acid digestion, fusion, mercury analysis, and total cyanide. (The water leach and fusion procedures are PNL techniques; other procedures are EPA-based.) Inorganic analyses addressed four Test Plan objectives, as described in Section 2.3.

The Test Plan for the SST samples calls for duplicate and spike anaiyses by each of the inorganic test methods (except fusions) to obtain information about the reproducibility of results obtained with these methods and to validate the data generated from the water leach and the EP Toxicity procedures.

To evaluate inorganic test method performance, the EPA contract raboratory procedure. (CLP) SOW 787 criteria for sensitivity, reproducibility of duplicate analyses, and spike recovery were applied to all test results, although the criteria are only intended for acid-digested soil and water samples. Detection $1 \mathrm{imits}$ were estimated rather than measured precisely. For reference purposes only, the following criteria (which are similar to those used in SOW 787) are used throughout this report:

- Spike sample analysis--the acceptance range for spike recovery is $75 \%$ to $125 \%$.

- Ouplicate sample analysis--the relative percent differences (RPO) between duplicate sample analyses must be within $\leqslant 20 \%$ if the results of the element analyzed are at least five times the estimated methods detection limit. RPD is defined as $\{(S-0) /[(S+D) / 2]\} \times 100$, where $S=$ sample value and $D=$ duplicate value.

- ICP serial dilution--a five-fold dilution must agree with the original analys is to within a percent difference of $\pm 10 \%$ if the element analyzed is at least 50 times the estimated method detection limit. Percent difference is defined as $[(I-0) / 1] \times 100$, where I $=$ initial solution value and $D=$ diluted solution value. 


\subsection{IEST METHODS, RESULTS, AND DISCUSSION}

\subsubsection{Sample Preparation}

In accordance with the Test Plan, portions of SST sample 102-C were prepared for analyses for three analyte categories: 1) inorganic cations by ICP (inductively coupled plasma - atomic emission spectroscopy), 2) inorganic anions by ion chronatography (IC), and 3) total organic carbon (TOC) and tota 1 inorganic carbon (TIC). Solid samples from SST 102-C and SST 105-C were crushed, sieved, and homogenized as illustrated in Figure 1 of the Test Plan (see Appendix). (Sample 106-C was previously prepared for earlier tests using a similar process). Samples $105-C$ and 106-C were then fused for measurement of inorganic cations by ICP and for radiochemical analysis.

\subsubsection{Percent Solids Determination}

The percent solids content of two 1.0 - to $1.5-\mathrm{g}$ portions of SST $102-\mathrm{C}$ were determined by comparing the sample weight before and after drying at $103^{\circ} \mathrm{C}$ to $105^{\circ} \mathrm{C}$, as illustrated in Figure 2 of the Test Plan (see Appendix). The result, defined as [(sample dry weight/sample wet weight) $x$ 100], was approximately $94 \%$ solids for both samples.

\subsubsection{Water Leach}

As shown in Figure 3 of the Test Plan (see Appendix), the water leach procedure involved leaching the samples with deionized water (OIW) in an ultrasonic bath for $1 \mathrm{~h}$, filtering the solution through $0.45-\mu \mathrm{m}$ filters, and analyzing the filtered solutions. The ICP results for 38 elements are given in Table 2.1. The values in the columns labeled "Raw ICP $(\mu \mathrm{g} / \mathrm{mL})$ " are the observed elemental concentrations; the values in the colunns labeled "Corr. $(\mu \mathrm{g} / \mathrm{mL}) "$ are the observed elemental concentrations corrected for spectral interferences from $U$ and $A 1$. Elements that are followed by an (e) are not present in sufficient concentration for accurate results due to low sensitivity by ICP analysis and/or significant spectral corrections for $U$ and Al. Table 2.2 shows the effects of spectral interferences from a standard $U$ solution on elements analyzed by the ICP. Note that U significantly interferes with the Se, Sb, and $T 1$ analyses and, to a lesser degree, the $\mathrm{Si}$ and $\mathrm{P}$ analyses. Similar interferences occur from A1 (especially for As), but for most elements this is to a lesser degree than for $U$. The data in Table 2.1 demonstrate 
interferences clearly, since the raw ICP results for $\mathrm{Sb}, \mathrm{Se}$, and $\mathrm{Tl}$ are positive, whereas the values after correction for $U$ and $A l$ interference are negative, which mandates reporting a "less than" value or analysis by an a) ternative method. For those elements that have significant spectral interferences by ICP analysis, analys is by graphite furnace atomic absorption (GFAA) may be required. Note that for most elements the RPD is considerably larger than the $\pm 20 \%$ that is considered acceptable according to the performance criteria defined in Section 2.0. As discussed in Section 2.2, dissolution of these matrices in water will yield erratic results, which is reflected in these data.

The IC, TOC, and TIC results are presented in Table 2.3. The low spike recovery for $\mathrm{Cl}$ and $\mathrm{PO}_{4}$ cannot be readily explained. The average orthophosphate value of $1030 \mathrm{mg} / \mathrm{kg}$ from IC analys is of samples 1 and 2 is $17 \%$ Tower than the ICP $P$ value of $405 \mathrm{mg} / \mathrm{kg}$, if the latter is assumed to be all orthophosphate $(1242 \mathrm{mg} / \mathrm{kg})$. Total $P$ is measured by ICP, whereas IC is specific for orthophosphate ion. If some of the $P$ were present in other ionic forms, this might explain the higher ICP result.

\section{1 .4 EP Toxicity}

A modified EP Toxicity study was performed on duplicate $10-g$ portions of SST archive sample 102-C according to EPA SW 846, Method 1310, as shown in Figure 4 of the Test Plan (see Appendix). The study consisted of a spike recovery study for eight elements on the EP Toxicity list; analysis of $10-\mathrm{mL}$ aliquots of the filtered solutions after leaching with dilute acetic acid; and analys is of $5 X$ serial dilutions of the aliquots.

The results of the spike recovery study, measured by ICP analysis with the use of duplicate 10-g samples, are given in Table 2.4. Spike recovery values were anomalously high for $\mathrm{Cr}$, Se, and $\mathrm{Tl}$. Poor ICP sensitivity and significant spectral correction due to $U$ interference may have been the cause for the high values for Se and Tl; GFAA analysis may be required for these elements. The reason for the high $\mathrm{Cr}$ recovery is unknown.

Complete ICP analyses were performed on samples prepared by the EP Toxicity protocol. Results on both the original solutions and on $5 X$ serial dilutions are presented in Table 2.5. It is clear from the percent difference 
results for the undiluted and $5 x$ diluted measurements for the duplicate samples that the reproducibility of the serial dilution values is within acceptable limits for most of the elements. If acetic acid affects the ICP resuits, greater differences would be expected between the two solutions since the diluted sample contains only one-fifth the acetic acid concentration $(0.02 \mathrm{M}$ versus $0.1 \mathrm{M}$ ). The fact that the results of the $5 \mathrm{X}$ serial dilution are within the acceptance limits indicates that acetic acid concentration does not significantly affect the ICP results.

Table 2.6 also contains the EP Toxicity results for SST sample 102-C. However, the results are given in units of $\mathrm{mg} / \mathrm{kg}$ (rather than the typically reported $\mathrm{mg} / \mathrm{l}$ units) so that the results can be compared more directly with those of the samples prepared by acid digestion and by fusion. Note that for many elements the RPO between duplicate sample analyses is larger than the $\pm 20 \%$ that is considered acceptable according to the performance criteria defined in Section 2.0. As discussed in Section 2.2, dissolution of these matrices in dilute acetic acid can yield erratic results, which are reflected in these data.

\subsubsection{Acid Digestion}

The acid digestion and filtration portion of the sample preparation was performed in the hot cell according to SOW 787 using 1.0- to 1.5-g samples of SST 102-C. Since the sample preparation adhered to the CLP method as closely as was reasonably possible in the hot cell, no further discussion of the sample preparation for the acid digestion method is given in this report. This acid digestion method was selected over the SW 846 method since SW 846 required the solutions to be evaporated without boiling to near dryness, which would significantly increase the sample preparation time.

The ICP and GFAA results given in Table 2.7 show that the RPDs between duplicate analyses are within $\pm 20 \%$ except for the elements B, Cd, Cu, K, Si, $\mathrm{T1}$, and $\mathrm{V}$. All of these elements (except $\mathrm{Si}$ ) are at or near the estimated detection limit of the ICP analysis. During the acid digestion procedure, silicates partially dehydrate to insoluble $\mathrm{SiO}_{2}$. Since this dehydration is not reproducible, the $S i$ results may be erratic. However, $S i$ is currently not identified as an EPA priority pollutant. 
Also, five of the elements with poor spike recovery that are listed in Table 2.7 (i.e., As, $\mathrm{P}, \mathrm{Pb}, \mathrm{Sb}$, and $\mathrm{Tl}$ ) are noted as having poor instrument sensitivity and significant spectral interference from $U$ and $A 1$ when analyzed by ICP. Data for these elements can be used for comparison purposes only. Although corrections are a significant percentage of the "raw" intensity, the observed values agree reasonably well with the GFAA results for $\mathrm{Pb}$. A comparison of the ICP and GFAA results shows that Sb, Se, and $I 1$ cannot be analyzed at low concentrations with good accuracy by ICP due to poor ICP sensitivity and large spectral interference from $U$. These elements are candidates for GFAA analysis. Only $A$ s and $\mathrm{Pb}$ have potential for analysis by $I C P$, and only then in the absence of interferences such as $A I$ and $U$.

Results of serial dilution measurements on selected elements from the acid-digested samples are given in Table 2.8. The percent difference values for the serial dilution results are much less than $\$ 10 \%$, and thus chemical or physical interference effects would not be expected from the matrix.

\subsubsection{Fusion: ICP Analys is}

As shown in Figure 8 of the Test Plan (see Appendix), portions of SST sample $102-C$ were fused in the hot cell with $\mathrm{KOH}$ in a Ni metal crucible; a second fusion was also performed with $\mathrm{Na}_{2} \mathrm{O}_{2}$ in a $\mathrm{Zr}$ metal crucible. After cooling, the fused mixtures were dissolved in DIW. The solutions were transferred into volumetric flasks, acidified with $\mathrm{HCl}$, diluted to volume, and aliquots were removed from the hot cell for ICP analyses. The ICP analyses of the $\mathrm{KOH} / \mathrm{Ni}$ and the $\mathrm{Na}_{2} \mathrm{O}_{2} / \mathrm{Zr}$ fusions are presented in Table 2.9 for comparison of analytical methods. The RPD in the ICP results for the two fusion methods is within $\$ 20 \%$, except for sone cations that are near the estimated detection 1 imit of the ICP method or for cases that require significant spectral corrections due to interferences from $U$ and $A 1$.

Also, the precipitates filtered from the acid digestion of samples 1 and 2 from SST sample 102-C were fused, as shown in Figure 8 of the Test Plan (see Appendix), and analyzed. A summation of the results for the acid-soluble and acid-insoluble fused portions are given in Table 2.10. The major acidinsoluble constituents in these samples are $\mathrm{Al}, \mathrm{Ca}, \mathrm{Fe}, \mathrm{Mg}$, and $\mathrm{Si}$, indicating the presence of some type of zeolite or acid-insoluble mineral compound in the waste tank sample. 
Since SST samples $105-\mathrm{C}$ and $106-\mathrm{C}$ were fused and dissolved for radiochemical analysis (see Section 4.0); ICP analyses were also performed. The ICP results for these samples, as well as for SST sample 102-C, are tabulated in Table 2.11. The three tank samples show significant differences in chemical composition of the major constituents, which is expected.

\subsubsection{Comparison of Water Leach, EP Toxicity, Acid Digestion, and Total Fusion ICP Analysis Results}

Analytical results from the four methods used for sample preparation of archive SST sample 102-C for inorganic constituents are given in TabTe 2.12; these are reported in units of $\mathrm{mg} / \mathrm{kg}$ to allow direct comparison. As mentioned in Section 2.1.6, the acid-insoluble portion of the sample was also fused and analyzed. Thus, the sum of "Acid Digestion" and "Acid Insol Fusion" should be equal to the "Fusion" values, provided that none of the acid-insoluble precipitate was lost during the transfer of the filter to the metal crucible used for fusion of the sample.

Note: A $0.45-\mu m$ membrane disposable plastic filtration apparatus was used to filter the acid digestion solution in the hot cell. When the filtration apparatus was taken apart in the hot cell, some of the precipitate could have been lost. Therefore, the acidinsoluble results should be used for indication purposes only.

The AT result for the water leach sample is higher than the Al value for the EP Toxicity solution. The $\mathrm{PH}$ of the EP Toxicity leachate prior to acetic acid addition was 11.4. The $\mathrm{pH}$ of the water leach was not measured. However, if it is assumed that the $\mathrm{pH}$ of the water leach was similar to that measured for the EP Toxicity method, some of the Al should be in the form of a soluble aluminate. Since the final pH for the EP Toxicity method is adjusted to slightly acid or near neutral (pH 5.0 or until a specified amount of acetic acid has been added), all of the Al should be precipitated as hydroxide. other metal ions may coprecipitate as well during the formation of the flocculent aluminum hydroxide.

It is interesting that $P$ and $\mathrm{Zr}$ were lower for the EP Toxicity sample than for the water leach sample. However, it was observed that the water leach samples that were filtered through the $0.45-\mu \mathrm{m}$ filter coagulated a flocculent light-reddish precipitate when the solution was left undisturbed over the weekend. One plausible explanation is that the $\mathrm{Zr}$ and $\mathrm{P}$ may have 
existed as a colloidal suspension in the water leach sample. If so, when the $\mathrm{pH}$ was adjusted to 5.0 with acetic acid according to the EP Toxicity method, the colloid coprecipitated when the aluminate ion was converted to $\mathrm{Al}(\mathrm{OH})_{3}$, thus significantly reducing the concentration of the $\mathrm{Zr}$ and $\mathrm{P}$ in solution.

\subsubsection{Mercury Analysis by Cold Vapor Atomic Absorption (CVAA)}

The $\mathrm{Hg}$ analysis was performed on $1.1005 \mathrm{~g}$ and $1.3188 \mathrm{~g}$ samples using CLP SOW 787 method 245.5 with some modification, as described in Section 2.2. The $\mathrm{Hg}$ was determined on a Perkin-Elmer atomic absorption unit in an openfaced hood. The $\mathrm{Hg}$ values for the duplicate analyses were $0.568 \mathrm{mg} / \mathrm{kg}$ and $0.572 \mathrm{mg} / \mathrm{kg}$, giving a RPD of $2.4 \%$. A third sample weighing $1.3347 \mathrm{~g}$ was spiked with $1.5 \mu$ of $\mathrm{Hg}$; the spiked sample was treated in the same manner as the other two samples. The spike recovery was $97 \%$.

\subsubsection{Total Cyanide}

The analysis of total cyanide was performed using CLP SOW 787 method 335.2, rather than SW 846 method 9010 as described in the Test Plan. Method 335.2 was modified by substituting $\mathrm{MgSO}_{4}$ for $\mathrm{MgCl}_{2}$ as the catalyst for decomposition of the ferrocyanide complex. It was found that if $1 \mathrm{~g}$ of $\mathrm{NaNO}_{3}$ was added to the cyanide distillation apparatus containing $\mathrm{MgCl}_{2}$, very poor cyanide recovery was observed. When $\mathrm{MgSO}_{4}$ was substituted for $\mathrm{MgCl}_{2}$, the cyanide recovery improved dramatically. Due to the high nitrate concentrations in SST wastes, $\mathrm{MgSO}_{4}$ was used routinely in this analysis. Hach kits utilizing the addition of dry chemicals were used for colorimetric analysis. The cyanide values reported for duplicate analyses are $0.92 \mathrm{mg} / \mathrm{kg}$ and $1.10 \mathrm{mg} / \mathrm{kg}$, giving a RPD of $17.8 \%$. These values are significantly lower than the EPA reactivity limit of $250 \mathrm{mg} / \mathrm{kg}$. Total cyanide spike recovery was $87 \%$.

\subsection{PROBLEM AREAS AND CORRECTIVE ACTIONS}

\subsubsection{ICP Spectral Corrections}

All EPA ICP analysis protocols require that spectral corrections be applied to all elements to obtain background and interelement corrected results. The ICP analyses performed on the SST samples deviated from these requirements. The Applied Research Laboratory (ARL) ICP used to analyze these samples determines 12 of the 38 elements with the sequential spectrometer. 
The analysis time for each element on the sequential system is comparable to the analyses time for all 26 elements on the simultaneous system. Since one third of the required elements were determined sequentially, the time required to scan all of the element combinations to determine spectral correction factors would be prohibitive; therefore, no spectral correction factors were entered into any of the calculation programs. For the analysis results in this report, spectral corrections from $U$ and $\mathrm{Al}$ were calculated by hand and the corrections applied to each analysis element.

\subsubsection{Poor Reproducibility from Water Leach and EP Toxicity Methods}

The RPD values calculated from the water leach and EP Toxicity data are outside the control limit of $\$ 20 \%$ for most of the elements. This is true even though the concentrations for several of the elements are a factor of 5 greater than the estimated ICP detection limit.. If the RPD values for the duplicate sample analyses on the water leach and EP Toxicity measurements are compared with those for the acid digestion and fusion methods, the values for the latter two procedures are significantly better. This is because when samples are leached with water, or with dilute acetic acid as in the EP Toxicity method, the amount of a given element brought into solution can be highly variable due to small variations in acidity, alkalinity, particle size of the sample, and leaching time and temperature. This is not the case for the more robust acid digestion or fusion techniques.

\subsubsection{Modification to CVAA Method}

When a significant concentration of $\mathrm{Hg}(\mathrm{i} . \mathrm{e} .,>10 \mu \mathrm{g}$ ) was reduced to metaI with $\mathrm{SnCl}_{2}$ and air sparged into a $\mathrm{KMnO}_{4}$ solution, a significant portion of the elemental $\mathrm{Hg}$ was trapped in the fritted cylinder in the trap solution. Once trapped, the $\mathrm{Hg}$ could not be quantitatively recovered. The CVAA $\mathrm{Hg}$ method was modified in the following manner for the SST sample analyses.

1. After digestion of the sample with $\mathrm{XMnO}_{4}$, a portion of the sample was removed from the hot cell.

2. A measured aliquot of the $\mathrm{KMnO}_{4}$-treated sample was pipetted into the CVAA apparatus and the $\mathrm{Hg}$ was reduced with $\mathrm{SnCl}_{2}$ and analyzed.

3. The $\mathrm{Hg}$ in the sample was calculated using tine dilution of the sample aliquot analyzed and the volume of the solution in No. 1. 


\subsection{CONCLUSIONS RELATED TO TEST PLAN OBJECTIVES}

\subsubsection{To Determine if There Are Problems with Employing the Various Analytical Methods on the Test Samples}

No major difficulties were encountered in the water leach, EP Toxicity, acid digestion, or fusion procedures for inorganic analysis. It should be recognized that the reproducibility of water leach and EP Toxicity procedures will be very poor on samples where the major metal ions in the basic sludge are multivalent metal ions, since several of these ions would be precipitated as basic hydroxides. Poor reproducibilities are expected since most of the multivalent metal ions are not soluble in basic or slightly acidic solution. Since a significant portion of SST sample 102-C is Al, Ca, Fe, Mn, Ni, U, and $\mathrm{Si}$, the reproducibility of duplicate analyses for these elements is expected to be worse for water leach or EP Toxicity samples than for acid-digested samples. This was substantiated by the analyses that were performed.

An interesting observation from the results presented in Table 2.12 is that several of the metal ions that form insoluble hydroxides are higher in the water leach than in the EP Toxicity sample. When the acid waste from the separation process in the 200 Area chemical processing facilities was neutralized with $\mathrm{NaOH}$, the wastes were made basic to prevent corrosion of the steel SSTs. If the water leach of SST sample 102-C has a starting $\mathrm{pH}>11$, some of the Al will dissolve to form aluminate ions. This is indicated by the high Al content of the water leach sample. Aluminum is amphoteric; therefore, when the solution in the EP Toxicity procedure is neutralized with acetic acid to a $\mathrm{pH}$ of 5.0 , the soluble aluminate will be neutralized to a gelatinous A] $(\mathrm{OH})_{3}$ precipitate, which may coprecipitate any colloidal metal oxides or hydroxides dissolved by the initial water leach in the EP Toxicity procedure.

\subsubsection{To Determine if the ICP Has Sufficient Sensitivity for Analys is of of EP Toxicity Metal Ions (excluding $\mathrm{Hg}$ )}

Table 2.13 summarizes the conclusions of this part of the investigation. For the EP Toxicity metal ions $\mathrm{As}, \mathrm{Pb}$, and $\mathrm{Se}$, ICP has poor sensitivity, and significant corrections are required for $U$ interference. Elements $S e$ and $A s$ require such large spectral corrections for $A 1$ and $U$ that these results are not considered reliable at the reported concentration levels. 
If the $U$ content in SST sample 102-C were lower, ICP sensitivity would be sufficient to measure all of the EP Toxicity metal ions except Se. The $U$ concentrations in the duplicate analyses after extraction by the EP Toxicity procedure were 430 and $356 \mu \mathrm{g} / \mathrm{mL}$ (Table 2.5). Even this U concentration, however, requires spectral correction to $\mathrm{As}, \mathrm{Cr}, \mathrm{Pb}, \mathrm{Se}$, and $\mathrm{Ag}$ of between 50 and $90 \%$ of the "raw" intensities. GFAA analysis will be required to measure many of these elements by the EP Toxicity procedure when the samples contain high $U$ and/or Al.

\subsubsection{To Determine Which of the 22 EPA Pollutant Metal Ions Can Be Determined by ICP Analysis}

Table 2.14 summarizes the conclusions of this part of the investigation. As discussed previously, the ICP has low sensitivity and significant corrections are required because $U$ interferes with measurements of $\mathrm{As}, \mathrm{Pb}$, and Se; this is also the case for Sb and $\mathrm{Tl}$. For $\mathrm{Ag}, \mathrm{Be}, \mathrm{Cd}$, and $\mathrm{V}$ (for SST archive sample 102-C) spectral corrections in excess of $50 \%$ of the uncorrected ICP values were required. However, because these elements are easily detected, they are still considered measurable by ICP.

\subsubsection{To Determine if Mercury Can Be Determined by the CVAA Method}

The $\mathrm{Hg}$ analysis was performed in duplicate using CLP SOW 787 method 245.5, with modifications. As demonstrated by the excellent test results (i.e., a RPD of $2.4 \%$ and spike recovery of $97 \%$ ), $\mathrm{Hg}$ can be determined by CVAA. 
TABLE 2.1. SST Sample 102-C Water Leach Measurements by ICP Analys is

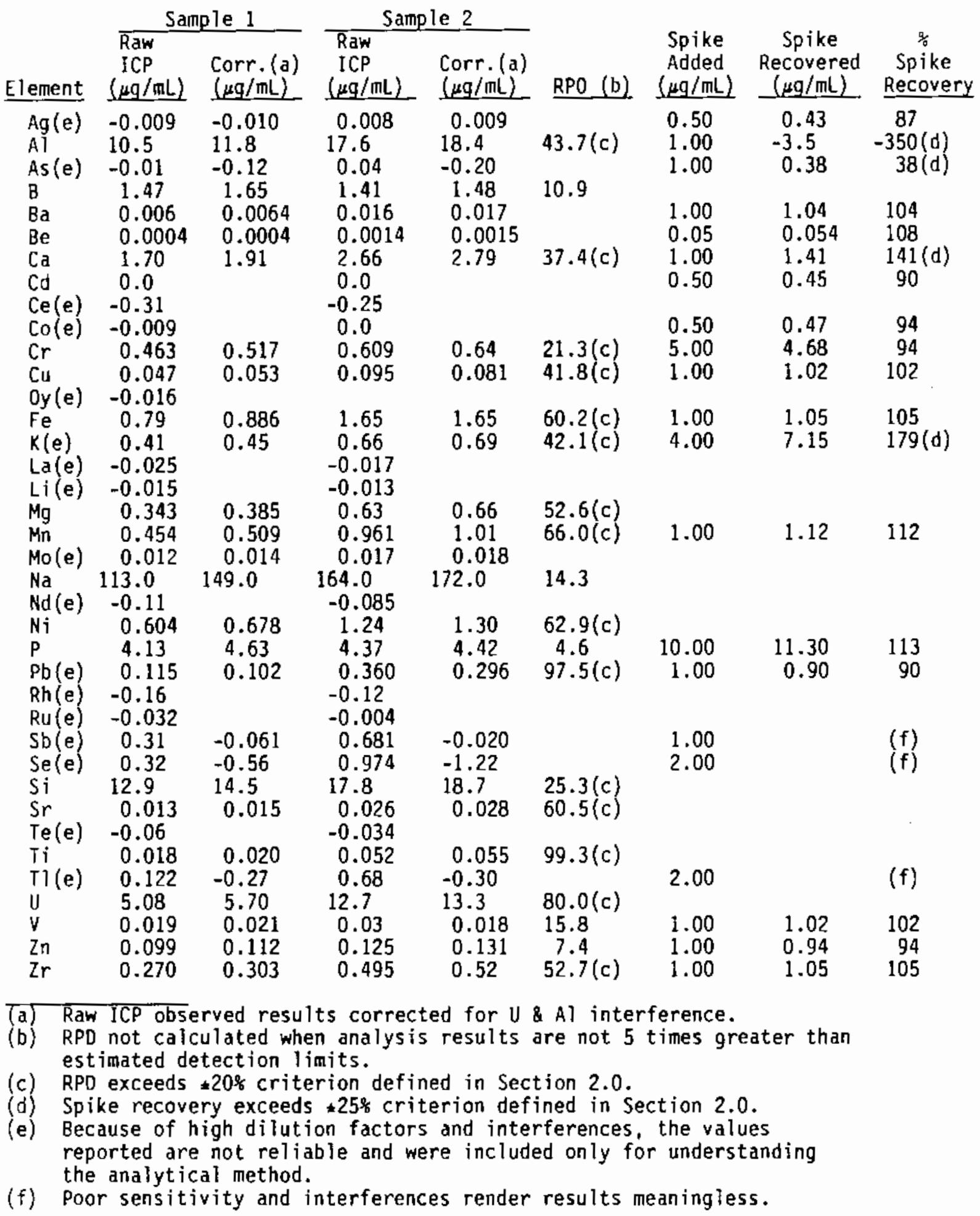


TABLE 2.2. Uranium Correction Factors for Elements Measured by the ARL ICP

\begin{tabular}{|c|c|}
\hline $\begin{array}{l}\text { Direct } \\
\text { Reader } \\
\text { Elements }\end{array}$ & Wave length \\
\hline $\begin{array}{l}\mathrm{Al} \\
\mathrm{B} \\
\mathrm{Ba} \\
\mathrm{Ca} \\
\mathrm{Ce} \\
\mathrm{Cr} \\
\mathrm{Dy} \\
\mathrm{Fe} \\
\mathrm{K} \\
\mathrm{La} \\
\mathrm{Li} \\
\mathrm{Mg} \\
\mathrm{Mn} \\
\mathrm{Mo} \\
\mathrm{Na} \\
\mathrm{Nd} \\
\mathrm{Ni} \\
\mathrm{Rh} \\
\mathrm{Ru} \\
\mathrm{Si} \\
\mathrm{Sr} \\
\mathrm{Te} \\
\mathrm{Ti} \\
\mathrm{Zn} \\
\mathrm{Zr}\end{array}$ & $\begin{array}{l}309.270 \\
249.680 \\
455.4 \\
393.370 \\
413.76 \\
267.720 \\
353.170 \\
259.94 \\
766.49 \\
379.480 \\
670.780 \\
279.52 \\
257.610 \\
202.030 \\
589.590 \\
406.110 \\
231.600 \\
343.49 \\
240.270 \\
288.160 \\
407.770 \\
214.280 \\
337.280 \\
213.860 \\
339.200\end{array}$ \\
\hline
\end{tabular}

$\mu \mathrm{g} / \mathrm{mL}$ Element

$\frac{\text { Interference from }}{100}$

$\mu g / \mathrm{mL} \mathrm{U} \quad \mu g / \mathrm{mL} \mathrm{U}$

1.07

0.113

5.08

0.022

0.005

0.682

0.329

0.0686

0.135

0.609

0.114

0.101

3.096

1.501

0.322

0.674

0.085

0.007

0.005

0.043

0.021

0.261

0.361

0.080

0.655

0.240

1.959

0.008

0.154

0.031

0.002

0.052
Potential

Interference (a)

?

Yes

Yes

?

Yes

?

Yes

Yes

?

Yes

Yes

Yes

?

Yes

Yes

?

Yes

Yes

?

?

Yes

Yes

Yes

Yes

Yes

Sequential

Elements

$\begin{array}{lcccc}\mathrm{Ag} & 328.068 & & 1.123 & ? \\ \mathrm{Cu} & 324.754 & 0.145 & 0.744 & ? \\ \mathrm{Be} & 313.042 & 0.009 & 0.044 & ? \\ \mathrm{~V} & 292.402 & 0.108 & 0.519 & ? \\ \mathrm{Tl} & 276.787 & 7.777 & 37.57 & ? \\ \mathrm{Co} & 228.616 & 0.050 & 0.240 & ? \\ \mathrm{~Pb} & 220.353 & 0.477 & 1.982 & ? \\ \mathrm{Sb} & 206.833 & 6.210 & 33.56 & \text { No } \\ \mathrm{P} & 214.914 & 1.264 & 5.057 & \text { No } \\ \mathrm{Se} & 196.026 & 17.05 & 79.13 & \text { No } \\ \mathrm{As} & 193.696 & 1.911 & 6.987 & ? \\ \mathrm{Cd} & 226.502 & 0.026 & 0.039 & \text { Yes }\end{array}$

(a) "Yes" (or "No") indicates there is (or is not) a potential to minimize interference effects by the use of off-peak background correction techniques. "?" indicates the potential is unknown. 
TABLE 2.3. Anion Analysis of Water Leach from SST Sample 102-C

\begin{tabular}{|c|c|c|c|c|c|c|}
\hline Anion & $\begin{array}{l}\text { Sample } 1 \\
\text { (mg/kg) }\end{array}$ & $\begin{array}{l}\text { Sample } 2 \\
(\mathrm{mg} / \mathrm{kg})\end{array}$ & RPD & $\begin{array}{c}\text { Spike } \\
\text { Added } \\
(\mathrm{mg} / \mathrm{kg})\end{array}$ & $\begin{array}{c}\text { Spike } \\
\text { Recovered } \\
\text { (mg/kg) }\end{array}$ & $\begin{array}{r}\% \text { Spike } \\
\text { Recovery }\end{array}$ \\
\hline $\begin{array}{l}\mathrm{F} \\
\mathrm{Cl} \\
\mathrm{NO}_{2} \\
\mathrm{NO}_{3} \\
\mathrm{PO}_{4} \\
\mathrm{SO}_{4} \\
\mathrm{TIC}(\mathrm{c}) \\
\mathrm{TOC}(\mathrm{c})\end{array}$ & $\begin{array}{r}301 \\
388 \\
3,400 \\
9,900 \\
1,140 \\
835 \\
3,900 \\
262\end{array}$ & $\begin{array}{r}260 \\
342 \\
3,000 \\
9,690 \\
910 \\
814 \\
3,280 \\
284\end{array}$ & $\begin{array}{c}14.6 \\
12.6 \\
12.5 \\
2.1 \\
22.4(\mathrm{~b}) \\
2.6 \\
17.2 \\
8.1\end{array}$ & $\begin{array}{r}200 \\
370 \\
13,400 \\
1,500 \\
1,150 \\
2,860\end{array}$ & $\begin{array}{r}190 \\
185 \\
14,600 \\
1,105 \\
805 \\
2,586\end{array}$ & $\begin{array}{l}95 \\
50(a) \\
110 \\
74(a) \\
70(a) \\
90\end{array}$ \\
\hline
\end{tabular}

(a) Spike recovery exceeds $\pm 25 \%$ criterion defined in Section 2.0 .

(b) RPD exceeds $\pm 20 \%$ criterion defined in Section 2.0.

(c) TIC = Total inorganic carbon; TOC = Total organic carbon.

TABLE 2.4. EP Toxicity Measurements and Spike Recovery Study by ICP Analys is for SST Sample 102-C

\begin{tabular}{|c|c|c|c|c|c|c|}
\hline \multirow[b]{2}{*}{$\begin{array}{l}\quad \text { EP } \\
\text { Toxicity } \\
\text { Element } \\
\end{array}$} & \multicolumn{3}{|c|}{ EP Toxicity Measurements } & \multicolumn{3}{|c|}{ Spike Recovery Measurements } \\
\hline & $\begin{array}{l}\text { Sample 1 } \\
(\mu \mathrm{g} / \mathrm{mL})\end{array}$ & $\begin{array}{l}\text { Samp le } 2 \\
\text { ( } \mu \mathrm{g} / \mathrm{mL})\end{array}$ & RPD & $\begin{array}{c}\text { Spike } \\
\text { Added } \\
\text { ( } \mu \mathrm{g} / \mathrm{mL} \text { ) }\end{array}$ & $\begin{array}{c}\text { Spike } \\
\text { Recovered } \\
(\mu \mathrm{g} / \mathrm{mL})\end{array}$ & $\begin{array}{l}\text { \% Spike } \\
\text { Recovery }\end{array}$ \\
\hline $\begin{array}{l}\mathrm{Ag}(\mathrm{d}) \\
\mathrm{As}(\mathrm{d}) \\
\mathrm{Ba} \\
\mathrm{Cd}(\mathrm{d}) \\
\mathrm{Cr} \\
\mathrm{Ha}(\mathrm{c})\end{array}$ & $\begin{array}{l}0.003 \\
1.63 \\
0.018 \\
0.009 \\
1.46 \\
0.0066\end{array}$ & $\begin{array}{l}0.17 \\
2.39 \\
0.02 \\
0.068 \\
1.74 \\
0.0063\end{array}$ & $\begin{array}{c}193(a) \\
37.8(a) \\
10.5 \\
153(a) \\
17.5 \\
4.7\end{array}$ & $\begin{array}{l}5.0 \\
5.0 \\
5.0 \\
1.0 \\
5.0\end{array}$ & $\begin{array}{l}4.63 \\
4.42 \\
4.96 \\
0.99 \\
7.25\end{array}$ & $\begin{array}{c}93 \\
88 \\
99 \\
99 \\
145(b)\end{array}$ \\
\hline $\begin{array}{l}\text { Pb (d) } \\
\text { Se(d) }\end{array}$ & $\begin{array}{l}0.07 \\
0.5\end{array}$ & $\begin{array}{l}0.54 \\
8.6\end{array}$ & $\begin{array}{l}154(a) \\
178(a)\end{array}$ & $\begin{array}{l}5.0 \\
1.0\end{array}$ & $\begin{array}{l}4.10 \\
3.90\end{array}$ & $\begin{array}{c}82 \\
390(b)\end{array}$ \\
\hline
\end{tabular}

(a) RPD exceeds $\pm 20 \%$ criterion defined in Section 2.0 .

(b) Spike recovery exceeds $\pm 25 \%$ criterion defined in Section 2.0.

(c) $\mathrm{Hg}$ analyses performed by CVAA.

(d) Because of high dilution factors and interferences, the values reported are not reliable and were included only for understanding the analytical method. 
TABLE 2.5. Results of $5 X$ Dilution on EP Toxicity Measurements by ICP for SST Sample 102-C

\begin{tabular}{|c|c|c|c|c|c|c|}
\hline Element & $\frac{\text { Sample } 1}{\text { Direct }}$ & $\frac{(\mu \mathrm{g} / \mathrm{mL})}{5 \times \mathrm{Di}}$ & $\begin{array}{c}\text { Percent } \\
\text { Difference }\end{array}$ & $\frac{\text { Sample } 2}{\text { Direct }}$ & $\frac{(\mu \mathrm{g} / \mathrm{mL})}{5 \times 0 \mathrm{DiT}}$ & $\begin{array}{c}\text { Percent } \\
\text { Difference }\end{array}$ \\
\hline $\begin{array}{l}\mathrm{Ag}(\mathrm{c}) \\
\mathrm{A} 1 \\
\mathrm{As}(\mathrm{c}) \\
\mathrm{B} \\
\mathrm{Ba} \\
\mathrm{Be} \\
\mathrm{Ca} \\
\mathrm{Cd} \\
\mathrm{Ce}(\mathrm{c}) \\
\mathrm{Co}(\mathrm{c}) \\
\mathrm{Cr} \\
\mathrm{Cu} \\
\mathrm{Dy}(\mathrm{c}) \\
\mathrm{Fe}(\mathrm{c}) \\
\mathrm{K} \\
\mathrm{La}(\mathrm{c}) \\
\mathrm{Mg} \\
\mathrm{Mn} \\
\mathrm{Mo}(\mathrm{c}) \\
\mathrm{Na} \\
\mathrm{Nd}(\mathrm{c}) \\
\mathrm{Ni} \\
\mathrm{P}(\mathrm{c}) \\
\mathrm{Pb}(\mathrm{c}) \\
\mathrm{Rh}(\mathrm{C}) \\
\mathrm{Ru}(\mathrm{c}) \\
\mathrm{Sb}(\mathrm{C}) \\
\mathrm{Se}(\mathrm{C}) \\
\mathrm{Si} \\
\mathrm{Sr} \\
\mathrm{Te}(\mathrm{c}) \\
\mathrm{Ti} \\
\mathrm{Tl}(\mathrm{c}) \\
\mathrm{U} \\
\mathrm{V} \\
\mathrm{Zn} \\
\mathrm{Zr}\end{array}$ & $\begin{array}{c}0.003 \\
17.4 \\
1.63 \\
1.20 \\
0.018 \\
0.001 \\
17.6 \\
0.009 \\
-0.09 \\
0.005 \\
1.46 \\
0.49 \\
-0.002 \\
-0.025 \\
10.8 \\
-0.009 \\
1.13 \\
0.611 \\
-0.001 \\
1340 . \\
-0.01 \\
0.206 \\
3.04 \\
0.07 \\
-0.04 \\
-0.04 \\
-0.2 \\
0.5 \\
112 . \\
0.54 \\
0.009 \\
0.010 \\
0.31 \\
430 . \\
0.116 \\
0.734 \\
0.004\end{array}$ & $\begin{array}{c}0.128 \\
18.2 \\
1.03 \\
7.97 \\
0.021 \\
0.0 \\
18.7 \\
0.0 \\
\\
1.60 \\
0.50 \\
\\
10.7 \\
1.28 \\
0.628 \\
1330 . \\
0.216 \\
2.16\end{array}$ & $\begin{array}{c}(a) \\
4.4 \\
37.0 \\
564(b) \\
(a) \\
(a) \\
5.8 \\
(a) \\
(a) \\
(a) \\
8.8 \\
2.0 \\
(a) \\
(a) \\
0.9 \\
(a) \\
11.7 \\
2.7 \\
(a) \\
0.8 \\
(a) \\
4.6 \\
29.0 \\
(a) \\
(a) \\
(a) \\
(a) \\
(a) \\
3.6 \\
5.3 \\
(a) \\
0.0 \\
(a) \\
8.8 \\
6.5 \\
11.6 \\
(a)\end{array}$ & $\begin{array}{c}0.17 \\
9.29 \\
2.39 \\
1.39 \\
0.02 \\
0.004 \\
1.4 .9 \\
0.068 \\
0.41 \\
0.037 \\
1.74 \\
0.40 \\
-0.027 \\
0.04 \\
9.9 \\
0.05 \\
1.02 \\
0.51 \\
0.02 \\
1210 . \\
0.18 \\
0.23 \\
4.35 \\
0.54 \\
0.3 \\
0.13 \\
0.1 \\
8.6 \\
107 \\
0.45 \\
0.15 \\
0.037 \\
3.1 \\
356 . \\
0.14 \\
0.51 \\
0.03\end{array}$ & $\begin{array}{l}9.43 \\
1.10 \\
0.46 \\
1260 . \\
0.15 \\
2.42\end{array}$ & $\begin{array}{c}0.59 \\
3.6 \\
165.0 \\
462(b) \\
(a) \\
(a) \\
5.1 \\
(a) \\
(a) \\
(a) \\
6.9 \\
10.0 \\
(a) \\
(a) \\
4.8 \\
(a) \\
7.3 \\
9.8 \\
(a) \\
4.0 \\
(a) \\
35.0 \\
44.0 \\
(a) \\
(a) \\
(a) \\
(a) \\
(a) \\
5.6 \\
4.3 \\
(a) \\
(a) \\
(a) \\
2.2 \\
43.0 \\
7.3 \\
(a)\end{array}$ \\
\hline
\end{tabular}

(a) RPD not calculated since "direct" results are not 50 times estimated detection limits.

(b) Reason for large percent difference is unknown, possible borosilicate glass contamination.

(c) Because of high dilution factors and interferences, the values reported are not reliable and were included only for understanding the analytical method. 
IABLE 2.6. EP Toxicity Results by ICP Analysis in Units of $\mathrm{mg} / \mathrm{kg}$ for SST Sample 102-C

\begin{tabular}{|c|c|c|c|}
\hline Element & $\begin{array}{l}\text { Sample } 1 \\
\text { (mg/kg) }\end{array}$ & $\begin{array}{l}\text { Sample } 2 \\
(\mathrm{mg} / \mathrm{kg})\end{array}$ & RPD \\
\hline $\mathrm{Ag}(\mathrm{d})$ & 0.006 & 3.4 & $(\mathrm{a}$ \\
\hline AI & 347 & 185 & $61(\mathrm{~b})$ \\
\hline As & 32 & 48 & $40(\mathrm{~b})$ \\
\hline$B$ & 24 & 28 & 15 \\
\hline $\mathrm{Ba}$ & 0.36 & 0.4 & (a \\
\hline $\mathrm{Be}$ & 0.02 & 0.08 & (a \\
\hline $\mathrm{Ca}$ & 350 & 297 & 16 \\
\hline $\mathrm{Cd}$ & 0.18 & 1.4 & (a \\
\hline $\mathrm{Ce}(\mathrm{d})$ & -1.8 & 8.2 & (a \\
\hline $\operatorname{Co}(d)$ & 0.1 & 0.8 & (a \\
\hline $\mathrm{Cr}(\mathrm{c})$ & 29 & 35 & 19 \\
\hline $\mathrm{Cu}(\mathrm{c})$ & 9.8 & 8.0 & 20 \\
\hline Dy (d) & -0.04 & -0.6 & (a \\
\hline $\mathrm{Fe}(\mathrm{d})$ & -0.5 & 0.8 & $(a$ \\
\hline $\mathrm{K}$ & 215 & 197 & \\
\hline $\operatorname{La}(d)$ & -0.18 & 1.0 & (a) \\
\hline $\mathrm{Mg}$ & 22 & 20 & 9.5 \\
\hline$M n$ & 12.1 & 10 & 19 \\
\hline Mo (d) & 0.02 & 0.4 & $\ldots$ \\
\hline & 26,700 & 24,000 & 11 \\
\hline $\operatorname{Nd}(c, d)$ & -0.2 & 3.6 & \\
\hline $\mathrm{Ni}(\mathrm{c})$ & 4.1 & 4.6 & 11 \\
\hline $\begin{array}{l}P(d) \\
P b(d)\end{array}$ & $\begin{array}{l}61 \\
1.4\end{array}$ & $\begin{array}{l}87 \\
11\end{array}$ & $35(\mathrm{~b})$ \\
\hline $\operatorname{Rh}(d)$ & 0.8 & 6.0 & (a) \\
\hline$R u(d)$ & -0.8 & 2.6 & (a) \\
\hline$S b(d)$ & -4 & 2 & (a) \\
\hline $\operatorname{Se}(d)$ & 10 & 170 & \\
\hline Si & 2,230 & 2,100 & 6 \\
\hline Sr & 11 & 9.0 & 20 \\
\hline $\operatorname{Te}(d)$ & 0.18 & 3.0 & (a) \\
\hline & 0.2 & 0.74 & (a) \\
\hline $11(d)$ & 8.0 & $\begin{array}{r}62 \\
7100\end{array}$ & \\
\hline $\begin{array}{l}U \\
V(c)\end{array}$ & 8,580 & 7.1002 .8 & 19 \\
\hline $\mathrm{Zn}$ & 14.6 & $10^{20}$ & 37 (b) \\
\hline $\mathrm{Zr}$ & 0.08 & 0.6 & (a) \\
\hline
\end{tabular}

(a) RPD not calculated; analys is results are not 5 times the estimated detection limit.

(b) RPD exceeds $\pm 20 \%$ criterion defined in Section 2.0.

(c) $U$ interference correction greater than $50 \%$ of element's raw intensity.

(d) Because of high dilution factors and interferences, the values reported are not reliable and were included only for understanding the analytical method. 
IABLE 2.7. Acid Digestion Measurements and Spike Recovery Study by ICP for SST Sample 102-C (including GFAA Results)

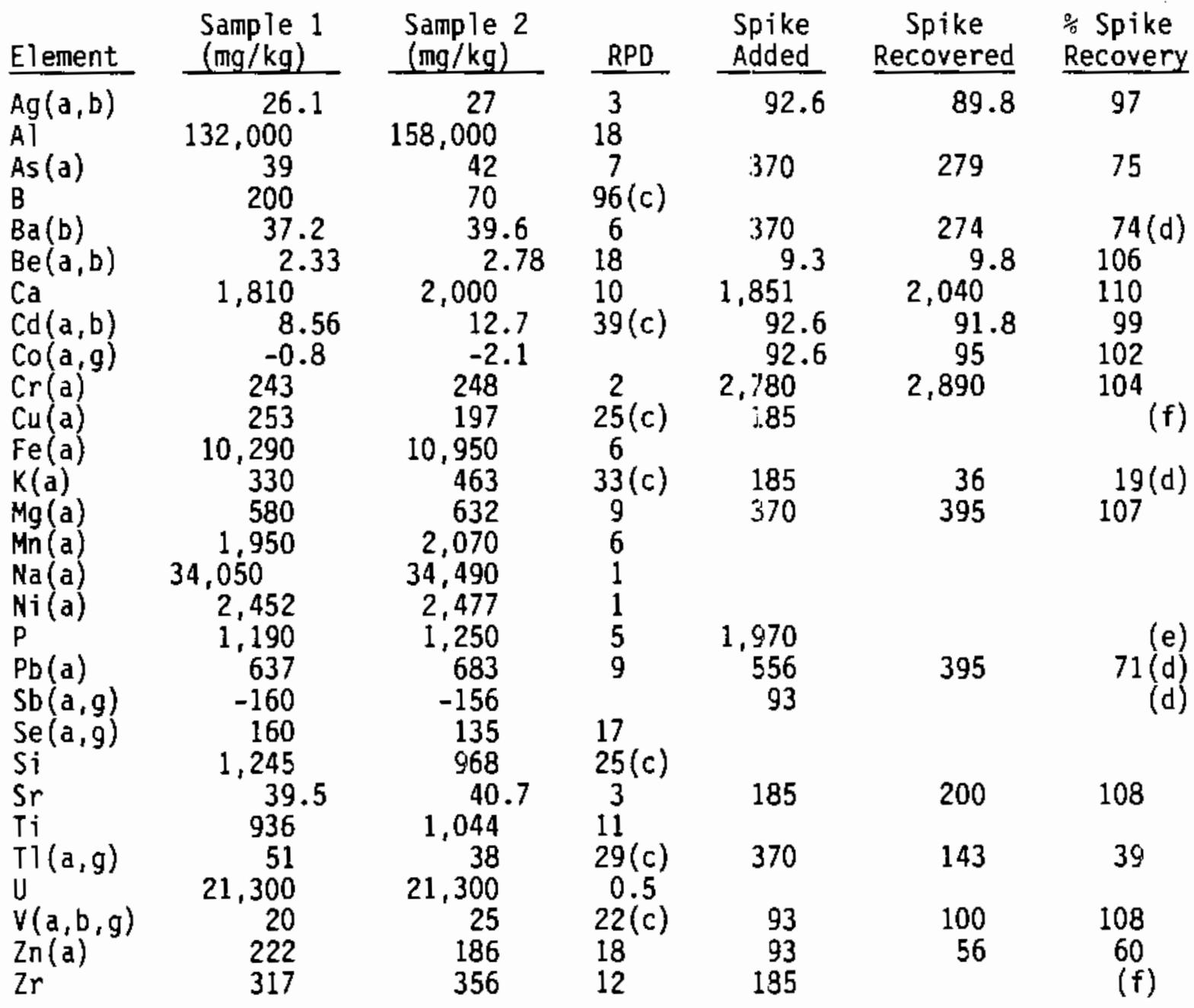

GRAPHITE FURNACE ATOMIC ABSORPIION RESULTS

As $=95 \mathrm{mg} / \mathrm{kg} \quad \mathrm{Pb}=780 \mathrm{mg} / \mathrm{kg} \quad \mathrm{Sb}=<30 \mathrm{mg} / \mathrm{kg}$

$\mathrm{Se}=<30 \mathrm{mg} / \mathrm{kg} \quad \mathrm{Tl}=<1 \mathrm{mg} / \mathrm{kg}$

(Note: No spike recoveries performed by GFAA)

(a) EPA pollutant metal ions.

(b) U interference correction greater than $50 \%$ of element's raw intensity.

(c) RPD exceeds $* 20 \%$ criterion defined in Section 2.0 .

(d) Spike recovery exceeds $* 25 \%$ criterion defined in Section 2.0

(e) $\mathrm{Zr}$ probably precipitated as a zirconium phosphate compound.

(f) $\mathrm{Cu}$ and $\mathrm{P}$ channel lost during spike analyses.

(g) Because of high dilution factors and interferences, the values reported are not reliable and were included only for understanding the analytical method. 
TABLE 2.8. ICP Serial Dilution Results of ACid Digestion of SST Sample 102-C

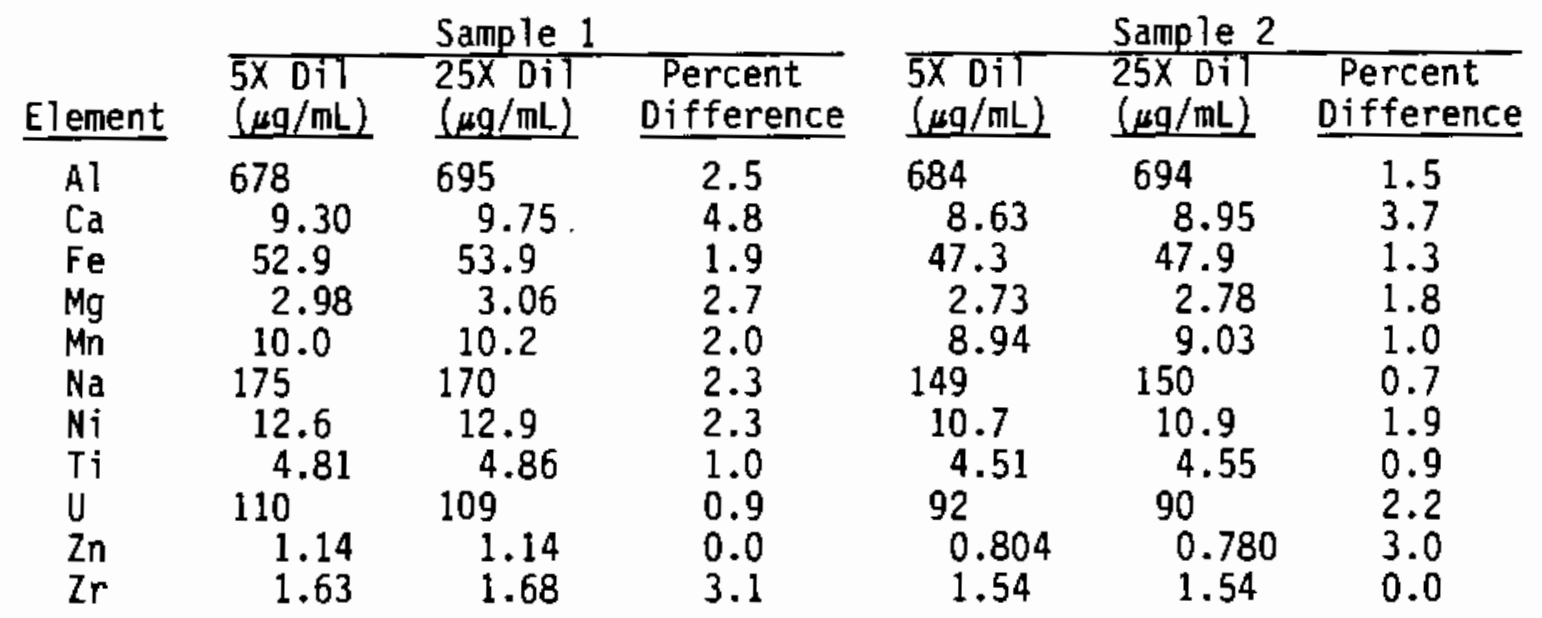

NOTE: Original digestates required a $5 X$ dilution in order to place the element concentrations within a linear range for ICP analysis. The dilution study was performed by diluting this $5 X$ solution another 5 fold. 
TABLE 2.9. Comparison of $\mathrm{KOH}$ and $\mathrm{Na}_{2} \mathrm{O}_{2}$ Fusion of ICP Anatys is for SST Sample 102-C

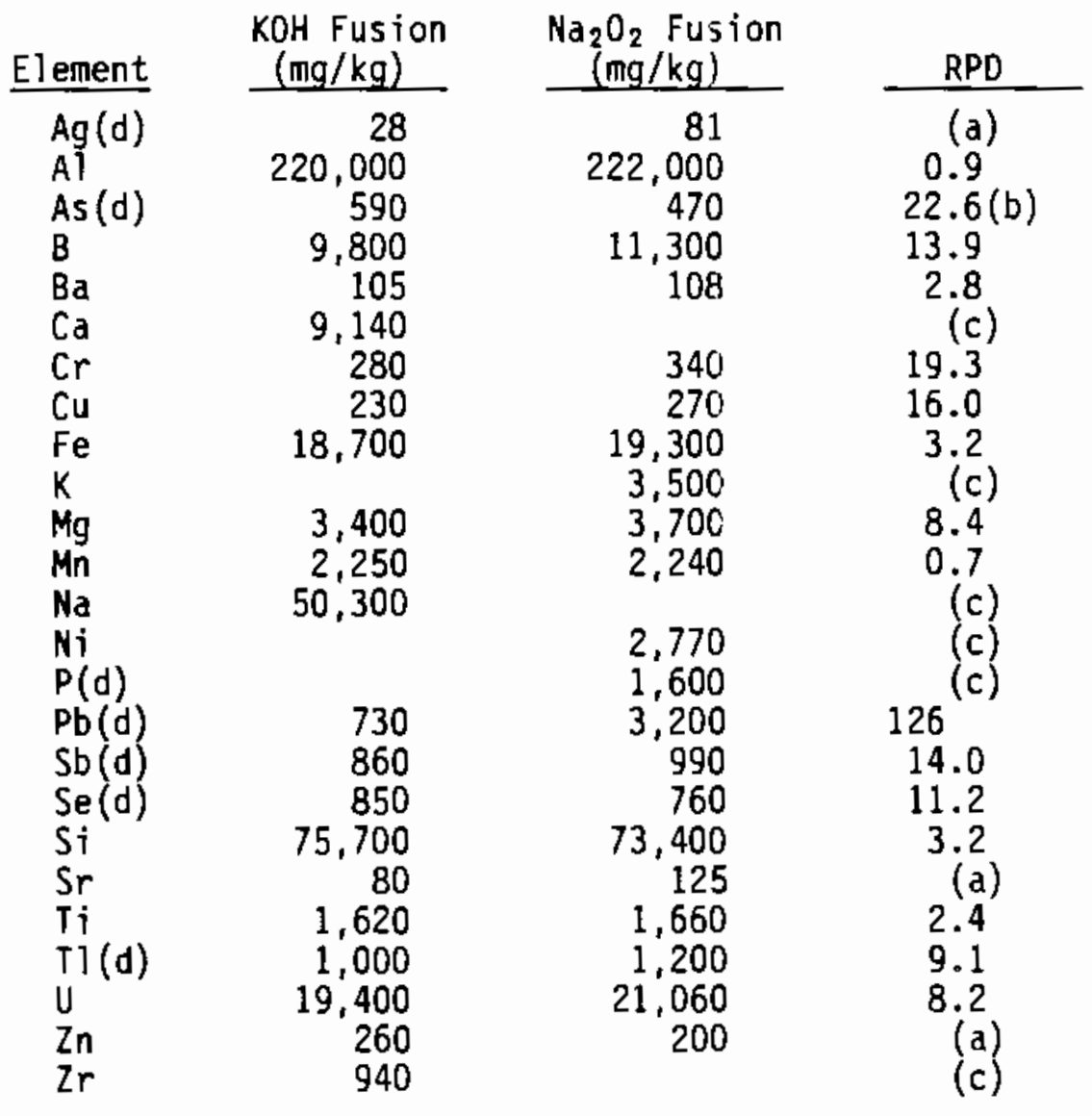

(a) RPD not calculated since analys is results are not 5 times the estimated detection limits.

(b) RPD exceeds $\pm 20 \%$ criterion defined in Section 2.0.

(c) Results for only one analysis due to the flux and crucible used.

(d) Because of high dilution factors and interferences, the values reported are not reliable and were included only for understanding the analytical method. 
TABLE 2.10. Sum of Acid Digestion and Fusion of Acid Insoluble Residue for SST Sample 102-C

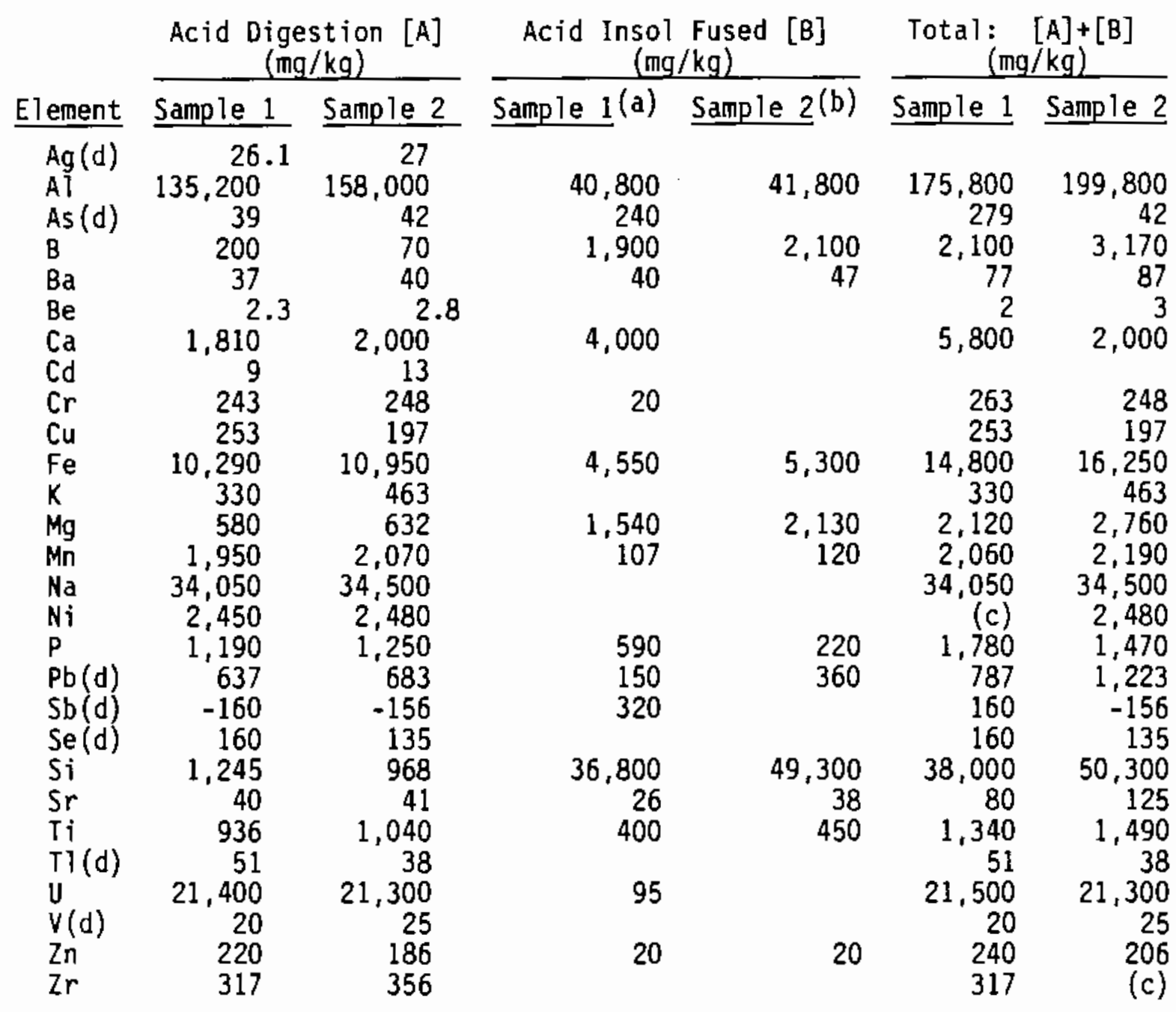

\footnotetext{
(a) $\mathrm{KOH} / \mathrm{Ni}$ Fusion

(b) $\mathrm{Na}_{2} \mathrm{O}_{2} / \mathrm{Zr}$ Fusion

(c) Fusion crucible contamination; only one fusion result summed.

(d) Because of high dilution factors and interferences, the values reported are not reliable and were included only for understanding the analytical method.
} 
TABLE 2.11. Comparison of ICP KOH Fusion Results for SST Samples 102-C, $105-C$, and $106-C$

\begin{tabular}{|c|c|c|c|}
\hline Element & $\begin{array}{l}\text { Sample } \\
102-c(a) \\
(\mathrm{mg} / \mathrm{kg})\end{array}$ & $\begin{array}{c}\text { Sample } \\
105-\mathrm{C} \\
(\mathrm{mg} / \mathrm{kg})\end{array}$ & $\begin{array}{c}\text { Sample } \\
106-C \\
(\mathrm{mg} / \mathrm{kg})\end{array}$ \\
\hline $\begin{array}{l}\mathrm{Ag}(\mathrm{c}) \\
\mathrm{AI} \\
\mathrm{As}(\mathrm{c}) \\
\mathrm{B} \\
\mathrm{Ba} \\
\mathrm{Ca} \\
\mathrm{Cd} \\
\mathrm{Ce}(\mathrm{c}) \\
\mathrm{Cr} \\
\mathrm{Cu} \\
\mathrm{Fe} \\
\mathrm{Mg} \\
\mathrm{Mn} \\
\mathrm{Mo} \\
\mathrm{Na} \\
\mathrm{Nd}(\mathrm{c}) \\
\mathrm{P} \\
\mathrm{Pb} \\
\mathrm{Sb}(\mathrm{c}) \\
\mathrm{Se}(\mathrm{c}) \\
\mathrm{Si} \\
\mathrm{Sr} \\
\mathrm{Ti} \\
\mathrm{TI}(\mathrm{c}) \\
\mathrm{U} \\
\mathrm{V}(\mathrm{c}) \\
\mathrm{Zn} \\
\mathrm{Zr}\end{array}$ & $\begin{array}{r}180 \\
225,000 \\
230 \\
150 \\
110 \\
9,400 \\
80 \\
60 \\
280 \\
280 \\
19,500 \\
3,520 \\
2,300 \\
150 \\
42,600 \\
60 \\
3,100 \\
890\end{array}$ & $\begin{array}{r}170 \\
246,000 \\
320 \\
300 \\
150 \\
1,600 \\
80 \\
270 \\
1,400 \\
160 \\
15,300 \\
330 \\
7,120\end{array}$ & $\begin{array}{r}2,100 \\
115,000 \\
390 \\
350 \\
350 \\
1,900 \\
\\
490 \\
1,750 \\
300 \\
82,400 \\
420 \\
4,500\end{array}$ \\
\hline
\end{tabular}

(a) Additional Sample 102-C fusion analysis performed for comparison with Samples 105-C and 106-C. Note values correspond well with those reported in

Table 2.9, except for $B$.

(b) For Sample 106-C the uranium is below the estimated detection limit of the ICP method-uranium by laser method yielded $8,200 \mathrm{mg} / \mathrm{kg}$ and $944 \mathrm{mg} / \mathrm{kg}$ for Sample $105-\mathrm{C}$ and $106-\mathrm{C}$, respectively.

(c) Because of high ditution factors and interferences, the values reported are not reliable and were included only for understanding the analytical method. 
TABLE 2.12. Direct Comparison of the Test Methods by ICP for SST Sample 102-C (in $\mathrm{mg} / \mathrm{kg}$ ) (a)

\begin{tabular}{|c|c|c|c|c|c|c|}
\hline Element & $\begin{array}{l}\text { Water } \\
\text { Leach }\end{array}$ & $\begin{array}{c}\text { EP } \\
\text { Toxicity } \\
\end{array}$ & $\begin{array}{c}{[A]} \\
\text { Acid } \\
\text { Digestion } \\
\end{array}$ & $\begin{array}{c}{[\mathrm{B}]} \\
\text { Acid Insol } \\
\text { Fusion } \\
\end{array}$ & {$[A]+[B]$} & Fusion \\
\hline $\mathrm{Ag}(\mathrm{b})$ & 0.0 & 1.7 & 27 & & & \\
\hline$A 1$ & 1,300 & 266 & 145,000 & 41,300 & 186,300 & 221,000 \\
\hline $\begin{array}{l}\text { As (b) } \\
\text { B }\end{array}$ & 140 & $\begin{array}{l}40 \\
26\end{array}$ & $\begin{array}{r}40 \\
235\end{array}$ & $\begin{array}{r}40 \\
2,000\end{array}$ & $\begin{array}{r}80 \\
2,200\end{array}$ & $\begin{array}{r}530 \\
10,600\end{array}$ \\
\hline Ba & 1.0 & 0.19 & 38 & 43 & $\begin{array}{r}80 \\
3\end{array}$ & 107 \\
\hline $\begin{array}{l}\mathrm{Be} \\
\mathrm{Ca}\end{array}$ & 210.08 & 324.05 & $1,900^{2 \cdot 0}$ & 4,000 & 5,900 & 9,140 \\
\hline $\begin{array}{l}\mathrm{Cd} \\
\mathrm{Co}(\mathrm{b})\end{array}$ & $\begin{array}{l}0.0 \\
0.4\end{array}$ & 0.71 & 11 & & 11 & \\
\hline $\mathrm{Cr}$ & 51 & 32 & 246 & & 246 & 310 \\
\hline $\begin{array}{l}\mathrm{Cu} \\
\mathrm{Fe}\end{array}$ & $50^{6.4}$ & 8.9 & $\begin{array}{r}225 \\
10.620\end{array}$ & 4900 & $\begin{array}{r}225 \\
15.500\end{array}$ & 10250 \\
\hline $\mathrm{K}$ & $50(b)$ & 206 & 400 & 4,500 & 400 & 3,500 \\
\hline $\mathrm{Mg}$ & 44 & 21 & 606 & 1,800 & 2,40 & 3,560 \\
\hline $\mathrm{Mn}$ & 65 & 11 & 2,010 & 114 & 2,120 & 2,240 \\
\hline Mo & 1.4 & 0.2 & & & & \\
\hline $\begin{array}{l}\mathrm{Na} \\
\mathrm{Ni}\end{array}$ & $\begin{array}{r}13,850 \\
84\end{array}$ & $\begin{array}{c}25,350 \\
4.4\end{array}$ & $\begin{array}{r}34,270 \\
2,464\end{array}$ & 4,300 & $\begin{array}{r}38,600 \\
2.464\end{array}$ & $\begin{array}{r}50,300 \\
2,770\end{array}$ \\
\hline $\mathrm{P}$ & 400 & $74(\mathrm{~b})$ & 1,220 & 400 & 1,600 & 1,600 \\
\hline $\begin{array}{l}\mathrm{Pb} \\
\mathrm{Se}(\mathrm{b})\end{array}$ & $\begin{array}{l}17(b) \\
58\end{array}$ & $90^{6.2(b)}$ & $\begin{array}{l}660 \\
150\end{array}$ & 250 & 900 & 2,000 \\
\hline & 1,430 & 2,160 & 1,106 & 43,000 & 44,100 & 74,500 \\
\hline $\begin{array}{l}\mathrm{Sr} \\
\mathrm{Te}(\mathrm{b})\end{array}$ & 1.8 & $\stackrel{10}{1.6}$ & 40 & 32 & & 102 \\
\hline $\begin{array}{l}\mathrm{Ti} \\
\mathrm{Tl}(\mathrm{b})\end{array}$ & 3.1 & 34.0 .5 & $\begin{array}{r}990 \\
44\end{array}$ & 425 & $\begin{array}{r}1,420 \\
44\end{array}$ & 1,640 \\
\hline $\begin{array}{l}U \\
V(b)\end{array}$ & $\begin{array}{l}820 \\
1.8\end{array}$ & $\begin{array}{r}7.840 \\
2.5\end{array}$ & $\begin{array}{r}21,300 \\
22\end{array}$ & & $\begin{array}{r}21,300 \\
22\end{array}$ & 20,230 \\
\hline $\mathrm{Zn}$ & 11 & 12 & 204 & 20 & 224 & 235 \\
\hline $\mathrm{Zr}$ & 35 & 0.3 & 336 & & 336 & 940 \\
\hline
\end{tabular}

\footnotetext{
(a) All reported results are averages of duplicate analyses.

(b) Because of high dilution factors and interferences, the values reported are not reliable and were included only for understanding the analytical method.
} 
TABLE 2.13. Summary of EP Toxicity Metal Ions by ICP

Sufficient

Element

$\mathrm{Ag}$

As

Ba

Cd
Sensitivity?

Probable

No

Yes

Yes
Sufficient

Element

$\mathrm{Cr}$

$\mathrm{Pb}$

$\mathrm{Se}$

No

No

TABLE 2.14. Summary of EPA Pollutant Metal Ions by ICP

\begin{tabular}{|c|c|c|c|c|c|}
\hline ETement & $\begin{array}{c}\text { Sufficient } \\
\text { Sensitivity? }\end{array}$ & Element & $\begin{array}{c}\text { Sufficient } \\
\text { Sensitivity? }\end{array}$ & Element & $\begin{array}{r}\text { Sufficient } \\
\text { Sensitivity? }\end{array}$ \\
\hline A1 & Yes & $\mathrm{cr}$ & Yes & $\mathrm{Na}$ & Yes \\
\hline $\mathrm{Ag}$ & Yes & Co & Yes & $\mathrm{Ni}$ & Yes \\
\hline As & No & $\mathrm{Cu}$ & Yes & $\mathrm{Pb}$ & Yes \\
\hline $\mathrm{Ba}$ & Yes & $\mathrm{Fe}$ & Yes & $\mathrm{Sb}$ & No \\
\hline $\mathrm{Be}$ & Yes & $\mathrm{K}$ & Yes & $\mathrm{Se}$ & No \\
\hline $\mathrm{Ca}$ & Yes & $M n$ & Yes & $\mathrm{Tl}$ & No \\
\hline $\mathrm{Cd}$ & Yes & $\mathrm{Mg}$ & Yes & $v$ & Yes \\
\hline $\mathrm{Zn}$ & Yes & & & & \\
\hline
\end{tabular}




\subsection{ORGANIC ANALYSIS}

The objective of the organic analysis task as stated in the Test Plan was to determine whether the EPA semivolatile organic method can be employed on SST samples. Semivolatile organic analyses were performed on methylene chloride extracts of SST samples. A description of the experimental work and the preliminary analytical results is followed by a discussion of the problems and some possible solutions. Conclusions related to the Test Plan objectives are presented in the final section on organic analysis.

The primary purpose of this project, "to gain additional experience with the analysis of SST matrices," was accomplished with respect to semivolatile organic analysis. Problems associated with the extraction process were encountered and a possible solution evaluated. Problems, most probably associated with the sampling process, were encountered that affected the gas chromatography/mass spectrometry (GC/MS) analysis. Laboratory development work will be required to solve these problems.

\subsection{TEST METHODS, RESULTS, AND DISCUSSION}

\subsubsection{Experimental}

Semivolatile organic analyses of a blank extract and two extracts of SST Sample 102-C were conducted by GC/MS. Extraction by sonication was performed in the hot cells. The low-level sample extraction process was used in the first extraction. Because the $5 \mathrm{~g}$ sample was very basic, it was acidified and a second extraction was performed to ensure acid compound extraction. The acidification technique used initially was to add a small quantity of methylene chloride to slurry the sample and slowly adding $4 \mathrm{M} \mathrm{H}_{2} \mathrm{SO}_{4}$ to a $\mathrm{pH}$ of about 2 as measured with pH indicator paper. When this extract was concentrated to $10 \mathrm{~mL}$, three phases formed, so an alternative acidification process was used (see Section 3.2.2). No problems were encountered in concentrating this extraction procedure with $1-\mathrm{g}$ aliquots.

The GC/MS analysis was run unsuccessfully on both the acidified and unacidified sample extracts (see Section 3.2.3). Extractions were repeated using the medium-level extraction procedure with $1-g$ aliquots. The GC screening procedure of CLP SOW 288 indicated that dilutions for this extraction 
should be about 3 to 0.5 (i.e., undiluted) for the unacidified and acidified aliquots. A second screening method, determination of TOC, yielded results that agree reasonably well with the $G C$ results if the comparison is estimated on a molar basis.

The concentrated extracts were analyzed by GC/MS according to SOW 288 . Before analysis, the mass spectrometer was tune checked, and the dajly calibration was run to verify the initial calibration. The internal standard checks were within SOW 288 limits for the analyses except for Perylene-d12 in two of the acidified sample extracts. The Perylene-d12 peak areas for the other acidified sample extracts were aiso very low.

\subsubsection{Surrogate and Matrix Spike Test}

To test for extraction efficiency and matrix effects, all of the sample aliquots were spiked (before the first extraction) with surrogate compounds and two sets of aliquots were spiked with matrix spike compounds. However, because the samples had to be diluted to lower NPH concentration and the surrogate and matrix spike compounds were divided between the two extracts for each aliquot, the concentrations measured fell below the calibration ranges for those compounds. Consequently, the nomal surrogate and matrix spike recovery reports are not included in this report.

\subsubsection{Target Compounds}

Results for three analyses are shown in CLP Form I (IB and IC) in Figures $3.1,3.2$, and 3.3. These results are for the blank and two extracts of the sample - one acidified (diluted 1 to 3 ) and one unacidified (diluted 1 to 10). The double extraction is described in Section 3.2.2.

There were no CLP target compounds found in the sample extracts (target compounds are listed in the $1 B$ and $1 C$ forms, "Senivolatile Organics Analysis Data Sheets"). The "U" signifies that the target compound was undetected at the listed concentration values $(\mu \mathrm{g} / \mathrm{kg}$ or $\mathrm{ppb})$, which are the contract required quantification limits (CRQL). The high values for the CRQL reflect the sample dilution. 


\subsubsection{Tentatively Identified Compounds}

Nontarget compounds were found in the two sample extracts. These are shown in the CLP Form $1 F$ in Figures 3.4, 3.5, and 3.6. Note that the estimated concentrations are reported in $\mu g / g(p p m)$ rather than the typical $\mu g / \mathrm{kg}(\mathrm{ppb})$ because of problems in the report generation software. The concentrations are estimated based on a response factors of 1.0 for all of the compounds.

The unacidified sample extract contained mostly alkane and siloxane compounds and the acidified sample extract contained mostly alkanes. Both extracts had what appeared to be oxidized alkanes and perhaps some amines, but their mass spectra did not match well with spectra in the National Institute of Standards and Technology (NIST) mass spectra library. The mass spectra matches became even worse for compounds with long chromatographic retention times.

The presence of high concentration alkanes is probably due to NPH in the core sampling process. The presence of siloxanes is probably due to the use of silicone-based lubricants, although gas chromatographic column degradation products have similar mass spectra.

\subsection{PROBLEM AREAS AND CORRECTIVE ACTIONS}

\subsubsection{Presence of NPH and Silicone-Based Lubricant Products}

The high concentration of alkanes mentioned in Section 3.1 .4 will be a problem with respect to the dilution required to prevent overloading the chromatography column. A large dilution will result in such high detection limits that many of the other organic constituents will not be detected. The alkanes are likely from the NPH hydrostatic fluid used in the sampling process.

The siloxanes observed are probably from silicone-based lubricants from the sampler, although they could be chromatography column decomposition products resulting from column reactions with sample constituents. In either case, column performance will be degraded because of stationary phase modifications.

Methods to remove NPH and the silicone compounds from the samples or to eliminate them from the sampling process must be developed if good 
identification and quantitation of organic constituents at low concentration are to be achieved.

\subsubsection{Extraction}

The acidification technique first tested involved adding a small quantity of methylene chloride to slurry the sample and slowly adding $4 \mathrm{M} \mathrm{H}_{2} \mathrm{SO}_{4}$ to a $\mathrm{pH}$ of about 2 as measured with $\mathrm{pH}$ indicator paper. Because of the lead glass window in the hot cell and probably the effect of methylene chloride on the $\mathrm{pH}$ paper dye, the acidification process was uncertain. When this extract was concentrated to $10 \mathrm{~mL}$, three phases had formed. The solution to this phase-formation problen was to add a calculated amount of $\mathrm{H}_{2} \mathrm{SO}_{4}$ to adjust the sample $\mathrm{pH}$ to 5 (based on the EP Toxicity experiment) and then add additional acid to ensure adequate acidity. Only 1/20 of the acid added using the first method was added by this method. No problems were encountered in concentrating this extract. In future work, a separate, weighed sample will be acidified to the desired $\mathrm{pH}$ using a known amount of $\mathrm{H}_{2} \mathrm{SO}_{4}$ so that a good estimate of the amount of acid needed can be made. Also, pH indicator paper will not be used because the paper could contaminate the sample.

The value of performing this $\mathrm{pH}$ adjustment before extraction for the very basic samples is seen by the absence of some acidic compounds in the unacidified sample extracts and their presence in the acidified sample extracts. However, the results are inconsistent. That is, some of the acid surrogate and matrix spikes are in the first extract, and other spikes are in the second extract.

In future analyses of very basic samples, the sample $\mathrm{pH}$ will be adjusted to 7 to 9 as described previously. The $\mathrm{pH}$-adjusted sample will then be extracted following the normal procedure. In this ph range, the acidic, basic, and neutrai compounds should extract satisfactorily. Although several multivalent metal ions form insoluble precipitates, these precipitates should have little, if any, effect on the extraction of the organic acids.

\subsubsection{Sample Concentration and Composition}

As mentioned, the sample was first extracted following the low-level procedure using a $5 \mathrm{~g}$ g sample. The GC/MS analysis was run on both the acidified and unacidified sample extracts with very deleterious effects on the GC 
column. Not only was the column overloaded, but it was rendered unusable for subsequent runs. No acidic compounds could be measured in calibration standards, and the baseline was noisy and increased significantly at temperatures above $200^{\circ} \mathrm{C}$. Attempts to recover the column were unsuccessful. The extractions were then repeated using the medium-level procedure with 1-g aliquots.

By this time, implementation and calibration of the GC screening procedure had been completed, and the low-level, concentrated extraction samples were screened. The results indicated that the unacidified sample extract was about 150 times too concentrated and the acidified sample about 15 times too concentrated based on protocol criteria. Since this screening would normaliy be done before the final evaporation of the $10 \mathrm{~mL}$ extracts, these extracts appeared to be about 15 and 1.5 times too concentrated for reliable analyses. For the medium-level extract with 1-g sample aliquots, rather than the 5 low-level extract, the screening indicated that dilutions should be about 3 to 0.5 (i.e., undiluted) for the unacidified and acidified aliquots.

A second screening method tested was the determination of TOC. Results for the TOC were $2.10 \%$ and $2.05 \% \mathrm{C}$ for two aliquots of the sample. Criteria from the SOW 288 screening protocol indicate that the medium-level extraction procedure should be used; the results from the TOC screening agree reasonably well with the GC results if the comparison is estimated on a molar basis.

To minimize GC/MS overload and fouling, the medium-level extracts were analyzed at several dilution ratios of the concentrated extracts. The minimum dilutions that could be analyzed without fouling or overload were 1 to 3 for the acidified sample extract and 1 to 10 for the unacidified sample extract. It would appear that these dilutions do not agree with the screening tests. It is likely that constituents in the extracts are causing the problem, rather than column overload.

In future analyses, the GC screening will be performed before the final evaporation step as a guide to the extraction level procedure to be followed. If an extract dilution is necessary, the extraction will be repeated with larger surrogate and matrix spike additions to account for the indicated dilution. The use of both screening methods is recommended until some pattern emerges after a number of analyses, which will hopefully identify the best screening method. 


\subsection{CONCLUSIONS RELATED TO TEST PLAN OBJECTIVES}

\subsubsection{To Determine whether the EPA Semivolatile Organic Method Can Be Employed on SST Samples}

Results indicate that the SST samples can be analyzed for semi-volatile organic compounds by the CLP SOW 288 procedures, but slight modifications will be required due to the problems associated with use of NPH and siliconebased materials in the SST sampling process. If silicone-based materials are to be used, a method to remove them from the sample extract must be found and implemented. The high concentration of NPH presents a problem in that the extract dilution may dilute organics that are in the SST sample to the point that they are difficult to both quantify and identify. Initially, tests will be run to determine if gel permeation chromatography (GPC) can be used for sample cleanup. It is highly reconmended that alternatives to GPC be sought and evaluated since it is unlikely that this method will solve the siloxane and NPH problems.

\subsection{DESCRIPTION OF DATA SHEETS}

Since the data sheets for organic analys is are unfamiliar to most readers, this section describes the format of the data sheets. Results for three analyses are shown in the format specified by EPA for CLP analyses. Results for EPA target compounds are shown in Figures 3.1, 3.2, and 3.3 for a blank, an acidified sample, and an unacidified sample respectively. values in the next to last column are the contract-required quantitation limits (CRQL) established as specified by EPA, and the "U" in the last column signifies that the target compound was undetected at the CRQL.

Compounds not on the EPA target list were found in the blank and the two sample extracts. These are shown in the CLP Forn $1 \mathrm{~F}$ in Figures $3.4,3.5$, and 3.6, respectively. The column headed RT is the retention time; the estimated concentration is in $\mu \mathrm{g} / \mathrm{g}$, while the previous figures were in $\mu \mathrm{g} / \mathrm{kg}$. Since the compounds are only tentatively identified, no Chemical Abstracts Service (CAS) number is given. 
18

SEMIVOLATILE ORGANICS ANALYSIS DATA SHEET

Lab Name: Battelle-PNL

Contract: $--\infty-1-\infty-1$
EPA SAMPLE NO.

$89-0073$
Lab Code: - - - ---- Case No.:

Matrix: (soil/water) sorl

Sample wt/vol: 1

Level: (low/med) MED

* Moisture: not dec.--- dec. --

Extraction: (Sepf/Cont/Sonc) SoNC

GPC Cleanup: (Y/N) N $\mathrm{NH}:-----$
Lab Sample ID: SOLVENT BLA

Lab File ID: >WPLOS

Date Received: $04 / 13 / 89$

Date Extracted:04/15/89

Date Analyzed: $4 / 28 / 89$

Dilution Factor: 1.00000

CAS NO.

COMPOUND

CONCENTRATION UNITS:

(ug/L or $u g / \mathrm{Kg}$ ) $u g / \mathrm{Kg}$

Q

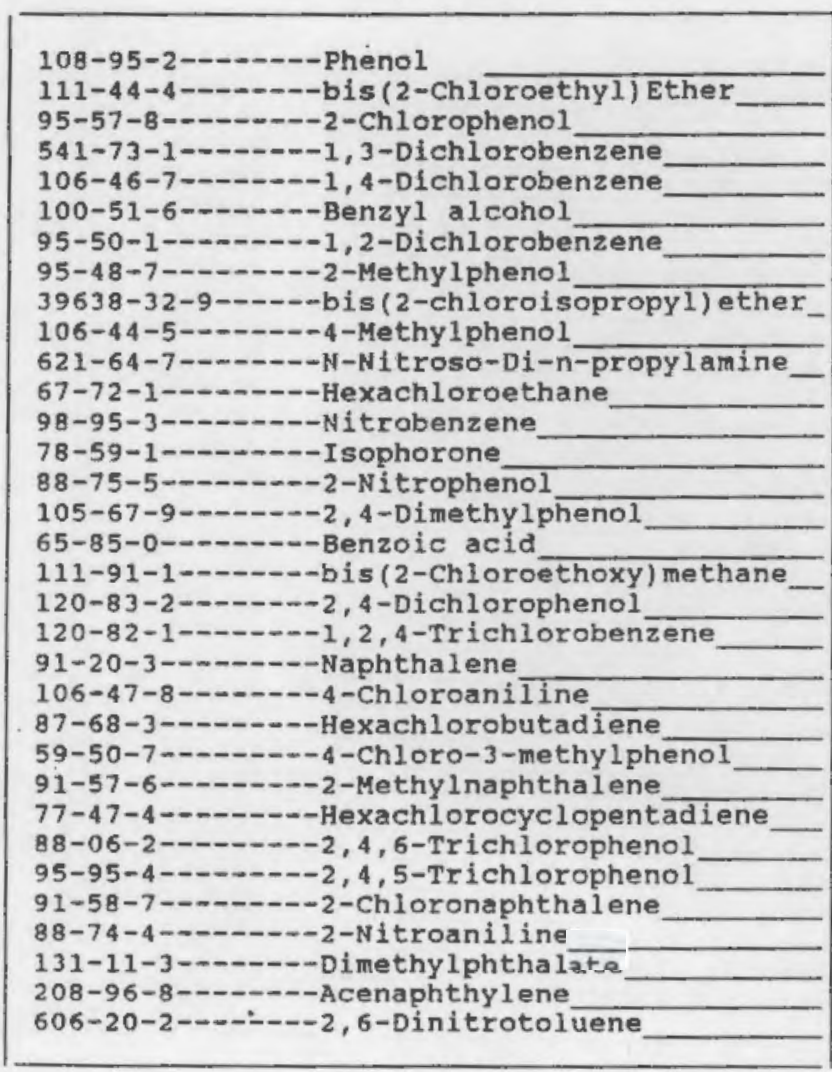

FORH I sV-1

20000 .

20000 .

20000 .

20000.

20000.

20000 .

20000 .

20000.

20000 .

20000 .

20000 .

20000.

20000.

20000.

20000.

20000 .

99000.

20000.

20000.

20000.

20000 .

20000.

20000.

20000.

20000.

20000.

20000.

99000 .

20000 .

99000 .

20000 .

20000 .

20000. 
$1 \mathrm{C}$

SEMIVOLATILE ORGANICS ANALYSIS DATA SHEET

Lab Name: Battelle-PNL

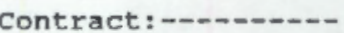

EPA SAMPLE NO.

$89-0073$

Lab Code:

Case No.:

SAS No.:

Matrix: (soil/water) soIL

Sample wt/vol: $1 \quad(g / m L) ~ G$

Level: (10w/med) MED

dec. ----

* Moisture: not dec.--.-

Extraction: (Sepf/Cont/Sonc) SONC

GPC Cleanup: (Y/N) N PH:-

CONCENTRATION UNITS:

CAS NO.

COMPOUND

$(u g / \mathrm{L}$ or $u g / \mathrm{Kg}$ ) $u g / \mathrm{Kg}$

Lab Sample ID: SOLVENT BLA

Lab File ID: >WPL05

Date Received: $04 / 13 / 89$

Date Extracted:04/15/89

Date Analyzed: $4 / 28 / 89$

Dilution Factor: 1.00000

(ug/L or ug/Kg) ug/Kg Q

99000.

20000.

99000 .

99000 .

20000 .

20000 .

20000 .

20000 .

20000 .

99000 .

99000 .

20000 .

20000 .

20000 .

99000 .

20000 .

20000 .

20000.

20000 .

20000 .

20000 .

40000 .

20000 .

20000 .

20000 .

20000 .

20000 .

20000 .

20000 .

20000.

20000.

20000 .

(1) - Cannot be separated from Diphenylamine

FIGURE 3.1. (contd) 
Lab code:

Case No.: -SAS No.:

Matrix: (soil/water) soIL

Sample wt/vol: $\quad 1.0115(\mathrm{~g} / \mathrm{mL}) \mathrm{G}$

Level: (low/med) MED

\$ Moisture: not dec.--- dec. ---

Extraction: (Sepf/Cont/Sonc) SoNC

GPC Cleanup: $(\mathrm{Y} / \mathrm{N}) \mathrm{N}$
Lab Sample ID: TK102C AC E Lab File ID: >WPL10 Date Received: 01/25/89 Date Extracted:03/28/89 Date Analyzed: 4/30/89 Dilution Factor: 1.00000 CONCENTRATION UNITS:

$(u g / L$ or $u g / K g) ~ u g / K g \quad Q$

CAS NO.

COHPOUND

59000

$108-95-2-0-----P h e n o l$

111-44-4------bis (2-Ch1oroethyl) Ether

95-57-8-2-- 2-Chlorophenol

541-73-1-...--1, 3-Dichlorobenzene

106-46-7---_--1, 4-Dichlorobenzene

100-51-6-------Benzy1 alcohol

95-50-1-n-..-1, 2-Dichlorobenzene

95-48-7-n-n-2-Methylphenol

39638-32-9-a---bis (2-chloroisopropy1) ether

106-44-5------4-Hethylphenol

621-64-7--.--N-Nitroso-Di-n-propylamine

67-72 1-n- - Hexachloroethane

98-95-3------ Nitrobenzene

78-59-1-------- Isophorone

$88-75-5-\ldots-\cdots-2-N i t r o p h e n o l$

105-67-9-...-.-2, 4-Dimethylphenol

65-85-0--------Benzoic acid

$111-91-1------b i s(2-$ Chloroethoxy) methane

120-83-2-..-- 2, 4-Dichlorophenol

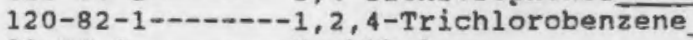

91-20-3------Naphthalene.

106-47-8------4-Chloroaniline

87-68-3-2.- Hexachlorobutadiene

59-50-7-n- - 4-Chloro-3-methyl phenol

91-57-6-----2-Methyl naphthalene

77-47-4--..--Hexachlorocyclopentadiene

88-06-2------ 2, 4, 6-Trichloraphenol

95-95-4-...-- 2, 4,5-Trichlorophenol

$91-58-7-1-2-C h l o r o n a p h t h a l e n e$

88-74-4---------2-Nitroaniline

131-11-3-----Dimethylphthalate

208-96-8 - - ..--Acenaphthylene

606-20-2-0---2, 6-Dinitrotoluene

FORM I SV-1

59000 . U

59000 .

59000 .

59000 .

59000 .

59000 .

59000.

59000.

59000 .

59000.

59000 .

59000.

59000.

59000.

59000 .

59000.

290000.

59000 .

59000 .

59000.

59000.

59000.

59000 .

59000.

59000.

59000.

59000.

290000.

59000.

290000.

59000 .

59000.

59000. 
Matrix: (soil/water) sord

Sample wt/val:

$1.0115(\mathrm{~g} / \mathrm{mL}) \mathrm{G}$

Level: (low/med) MED

\& Moisture: not dec..---

dec. ----

Extraction: (Sepf/Cont/Sonc) SONC

GPC Cleanup: (Y/N) N PH:-:--
Lab Sample ID: TK102C AC E

Lab File ID: >WPL10

Date Received: $01 / 25 / 89$

Date Extracted:03/28/89

Date Analyzed: $4 / 30 / 89$

Dilution Factor: 1.00000

CAS NO.

COMPOUND

CONCENTRATION UNITS : (ug/L or $u g / \mathrm{Kg}$ ) ug/ $\mathrm{Kg}$

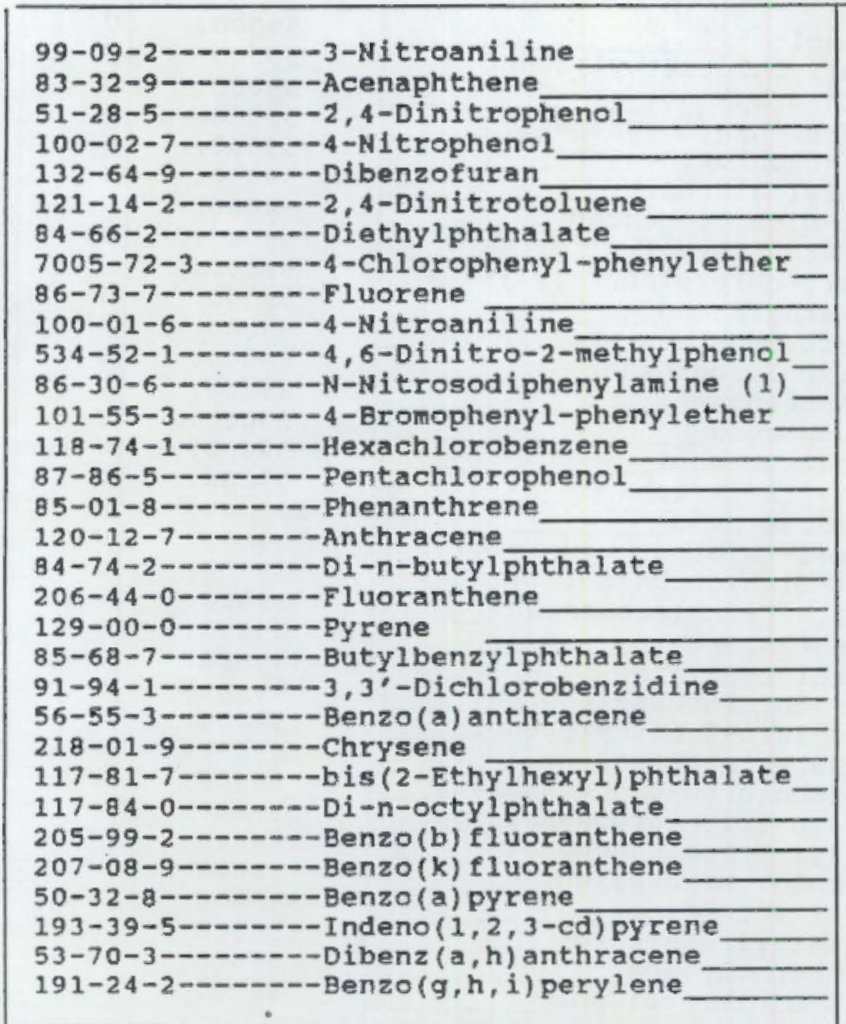

(1) - Cannot be separated from Diphenylamine

290000

59000 .

290000 .

290000 .

59000 .

59000 .

59000 .

59000 .

59000 .

290000 .

290000 .

59000 .

59000 .

59000 .

290000 .

59000 .

59000.

59000 .

59000.

59000 .

59000 .

120000 .

59000 .

59000 .

59000 .

59000 .

59000 .

59000 .

59000 .

59000 .

59000 .

59000 .

Q

FORM I SV-2

$1 / 87$ Rev.

FIGURE 3.2. (contd) 
$1 \mathrm{~B}$

SEMIVOLATILE ORGANICS ANALYSIS DATA SHEET

EPA SAMPLE NO.

89-0011

Iab Name: Battelle-PNL

Contract: - - - -

$89-0011$

Lab Code:

Case No.:

$-\cdots--$ SAS No.:

SDG No.:

Matrix: (soll/water) soIL

Sample wt/vol: $\quad 1.0115(\mathrm{~g} / \mathrm{mL}) \mathrm{G}$

Lab Sample ID: TK102C BN E

Level: (low/med) MED

Lab file ID: >WPL11

Moisture: not dec.---

dec. - -

Date Received: 01/25/89

Extraction: (Sepf/Cont/Sonc) soNC

Date Extracted:03/28/89

GPC Cleanup: (Y/N) $\mathrm{N}$

pH: - - - -

Date Analyzed: $4 / 30 / 89$

Dilution Factor: 1.00000

CAS NO.

COMPOUND

CONCENTRATION UNITS :

(ug/L or $\mathrm{ug} / \mathrm{Kg}$ ) ug/ $\mathrm{Kg}$

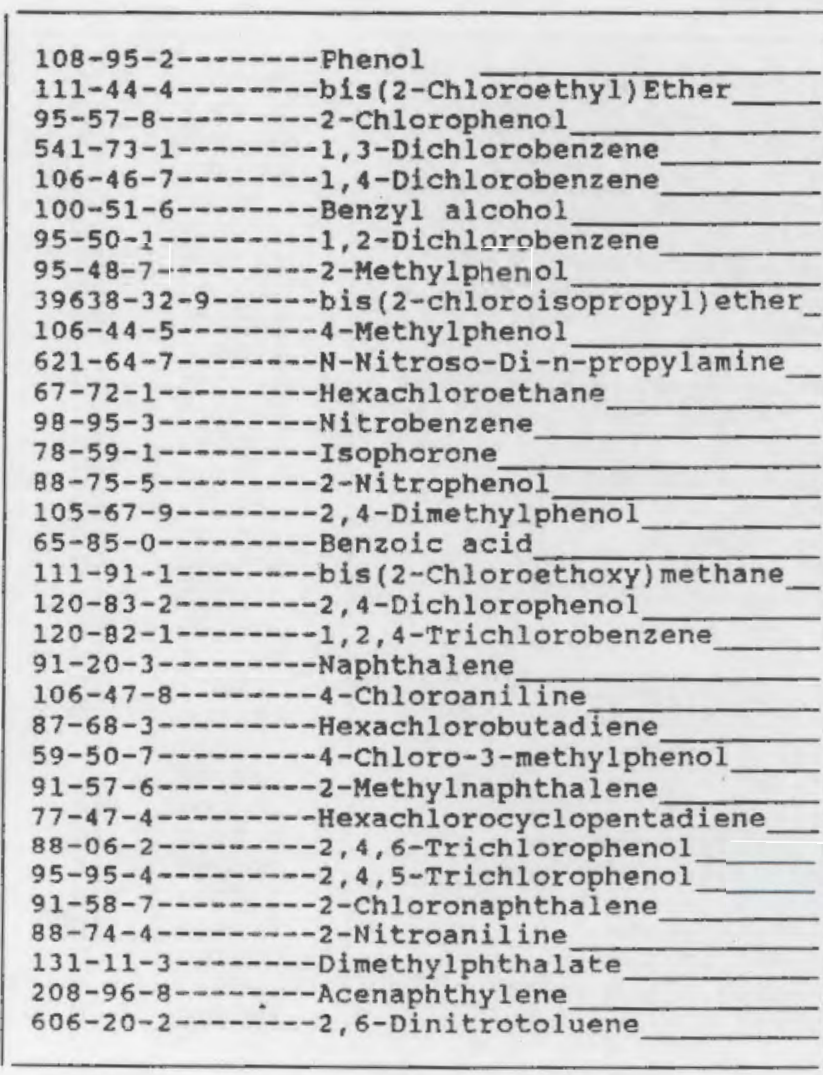

FORM I SV-1
200000.

200000 .

200000.

200000.

200000.

200000 .

200000 .

200000.

200000 .

200000 .

200000.

200000.

200000.

200000 .

200000.

200000 .

980000 .

200000 .

200000.

200000 .

200000.

200000 .

200000 .

200000 .

200000 .

200000.

200000 .

980000 .

200000.

980000 .

200000.

200000.

200000.

\section{$Q$}

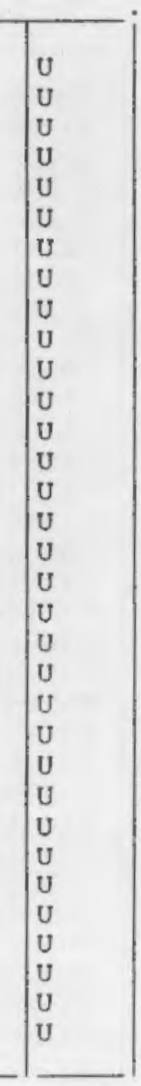

1/87 Rev.

FIGURE 3.3. Target Compounds, Unacidified Sample 
1C

SEMIVOLATILE ORGANICS ANALYSIS DATA SHEET

EPA SAMPLE NO.

Lab Name: Battelle-PNL

Contract:---------

89-0011

Lab Code: -

-SAS NO.:

SDG No.:

Matrix: (soll/water) sorL

Lab Sample ID: TK102C BN E

Sample wt/vol:

$1.0115(\mathrm{~g} / \mathrm{mL}) \mathrm{G}$

Lab File ID: >WPL11

Level: (1ow/med) MED

Date Received: $01 / 25 / 89$

\& Moisture: not dec.----

dec. ----

Date Extracted:03/28/89

Extraction: (Sepf/Cont/Sonc) SONC

Date Analyzed: $4 / 30 / 89$

GPC Cleanup: $\quad(\mathrm{Y} / \mathrm{N}) \mathrm{N} \quad \mathrm{pH}:-----$

Dilution Factor: 1.00000

CONCENTRATION UNITS :

CAS NO. COMPOUND (ug/L or $\mathrm{ug} / \mathrm{Kg}$ ) $\mathrm{ug} / \mathrm{Kg}$

\begin{tabular}{|c|c|c|}
\hline $99-09-2---0--0-3-$ Nitroaniline & 980000. & \\
\hline 83-32-9-------Acenaphthene & 200000 . & $\mathrm{U}$ \\
\hline 51-28-5-------2, 4-Dinitrophenol & 980000 . & $\mathrm{U}$ \\
\hline 100-02-7------- 4-Nitrophenol & 980000. & $\mathrm{u}$ \\
\hline $132-64-9--n---D i b e n z$ ofuran & 200000 . & $\mathrm{U}$ \\
\hline 121-14-2-------2, 4-Dinitrotoluene. & 200000 . & $\mathrm{U}$ \\
\hline 84-66-2-------Diethylphthalate & 200000 . & $\mathrm{u}$ \\
\hline 7005-72-3------4-Chlorophenyl-phenylether & 200000 . & $\mathrm{U}$ \\
\hline 86-73-7--------Fluorene & 200000 . & $\mathrm{U}$ \\
\hline 100-01-6--------4-Nitroaniline & 980000 . & $\mathrm{U}$ \\
\hline 534-52-1---- ---4, 6-Dinitro-2-methylphenol & 980000. & u \\
\hline $86-30-6-\ldots-N-N$ trosodiphenylamine (1) & 200000 . & $\mathrm{U}$ \\
\hline 101-55-3--- - - - Bromophenyl-phenylether & 200000 . & u \\
\hline $118-74-1---1--$ Hexachlorobenzene & 200000 . & $\mathrm{u}$ \\
\hline 87-86-5--------Pentachlorophenol & 980000. & $\mathrm{U}$ \\
\hline 85-01-B--..-- Phenanthrene & 200000. & $\mathrm{U}$ \\
\hline $120-12-7-0----$ Anthracene & 200000 . & $\mathrm{U}$ \\
\hline $84-74-2---1--0$ Di-n-butylphthalate & 200000. & $\mathrm{U}$ \\
\hline 206-44-0-------F1uoranthene & 200000 . & $\mathrm{U}$ \\
\hline $129-00-0--0----$-Pyrene & 200000 . & $\mathrm{U}$ \\
\hline 85-68-7- - - - - Butylbenzylphthalate & 200000 . & u \\
\hline $91-94-1------3,3^{\prime}$-Dichlorobenzidine & 390000 . & $\mathrm{U}$ \\
\hline $56-55-3---n-1$ Benzo (a) anthracene & 200000. & $\mathrm{u}$ \\
\hline 218-01-9--------Chrysene & 200000 . & $\mathrm{u}$ \\
\hline $117-81-7-0-0$ bis (2-Ethylhexyl)phthalate & 200000. & U \\
\hline $117-84-0----n-D i-n-o c t y l p h t h a l$ ate & 200000 . & $\mathrm{U}$ \\
\hline 205-99-2---ne--Benzo (b) fluoranthere & 200000. & $\mathrm{u}$ \\
\hline 207-08-9-_ - Benzo(k) fluoranthene- & 200000 . & U \\
\hline 50-32-8----- - Benzo (a) pyrene & 200000 . & $\mathrm{u}$ \\
\hline $193-39-5-\ldots---$ Indeno $(1,2,3-c \bar{d})$ pyrene & 200000 . & $\mathrm{U}$ \\
\hline 53-70-3-- Dibenz $(a, h)$ anthracene & 200000. & $\mathrm{U}$ \\
\hline 191-24-2-----Benzo $(g, h, i)$ perylene & 200000 . & \\
\hline
\end{tabular}

(1) - Cannot be separated from Diphenylamine

FIGURE 3.3 . (contd) 

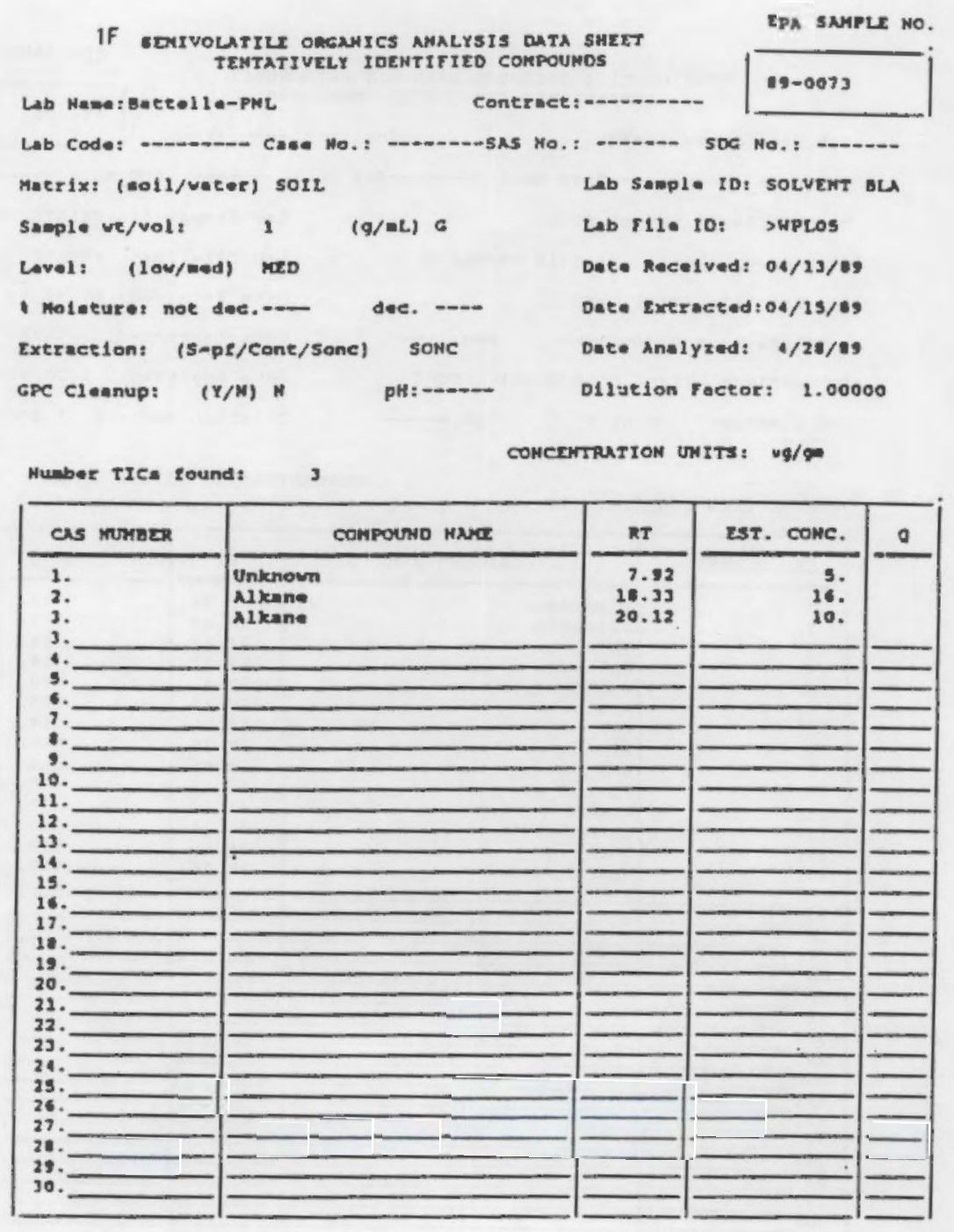

FIGURE 3.4. Tentatively Identified Compounds, Blank Sample 


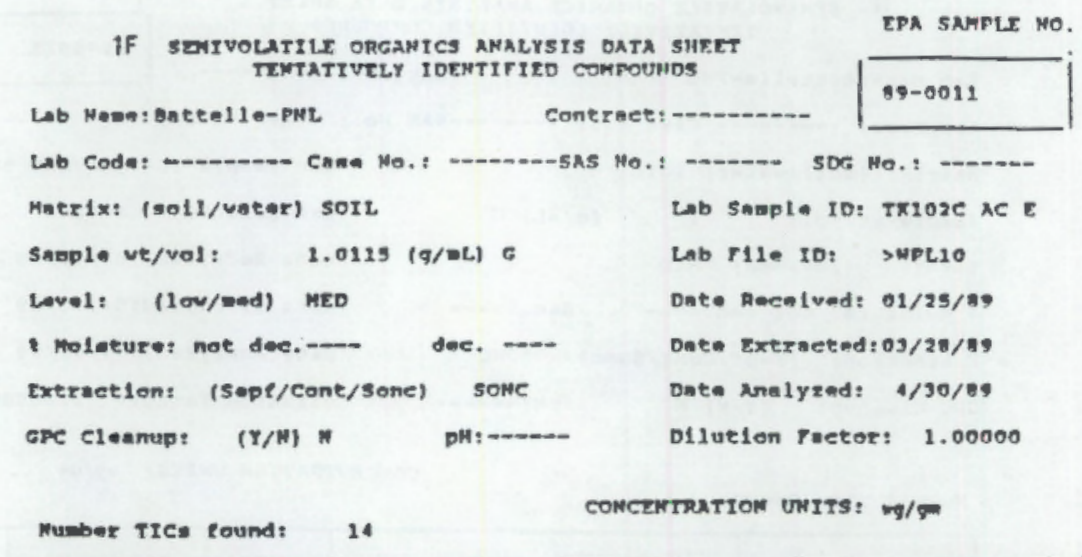

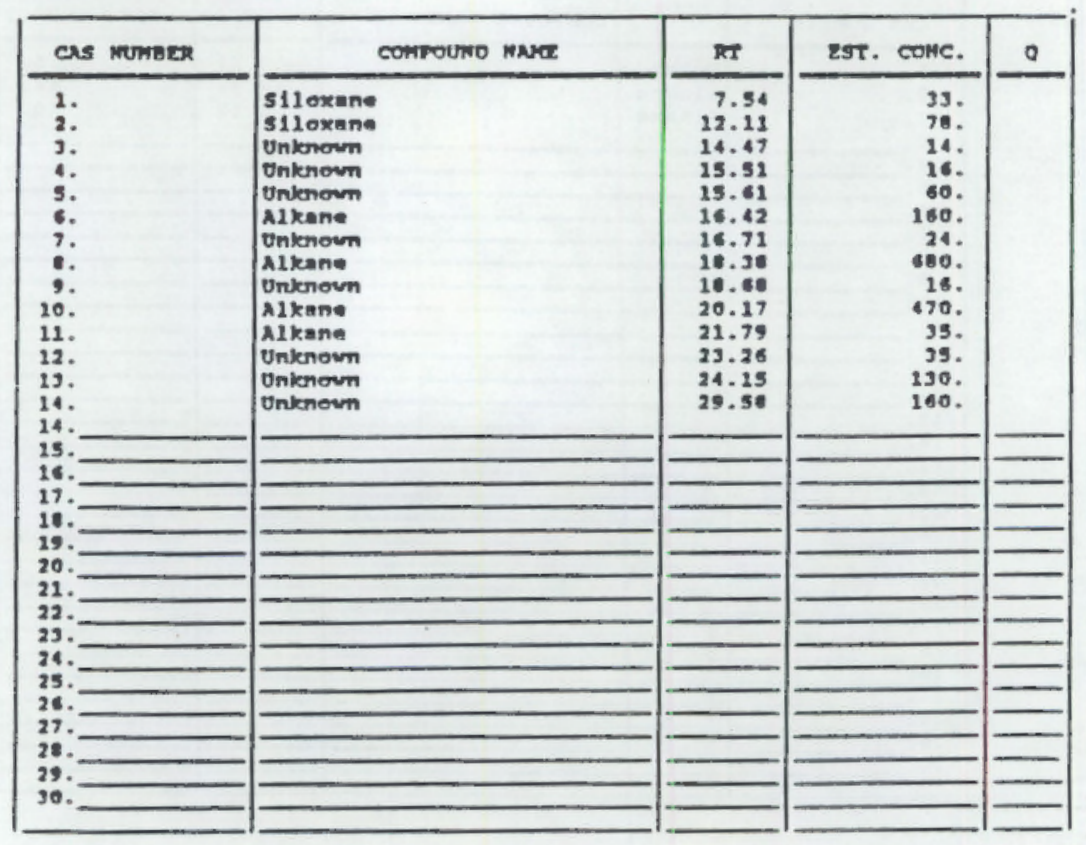

FIGURE 3.5. Tentatively Identified Compounds, Acidified Sample 
$1 \mathrm{~F}$

SEHIVOLATILE ORGANICS ANALYSIS DATA SHEET TENTATIVELY IDENTIFIED COMPOUNDS

Lab Name: Battelle-PNL

Contract:---------
EPA SAMPLE NO.

89-0011
Lab Code: --

Matrix: (soil/water) sorl

Sample wt/vol: $\quad 1.0115(\mathrm{~g} / \mathrm{mL}) \mathrm{G}$

Level: (low/med) MED

* Moisture: not dec.---- dec. -.--

Extraction: (Sepf/Cont/Sonc) SONC

GPC Cleanup: (Y/N) N PH:--

-SAS No.: Lab Sample ID: TK102C BN E Lab File ID: > HPLII Date Received: $01 / 25 / 89$ Date Extracted:03/28/89 Date Analyzed: $4 / 30 / 89$ Dilution Factor: 1.00000

CONCENTRATION UNITS :

Number TICs found: 21

(ug/L or $u g / K g$ ) ug/ Kog , seles

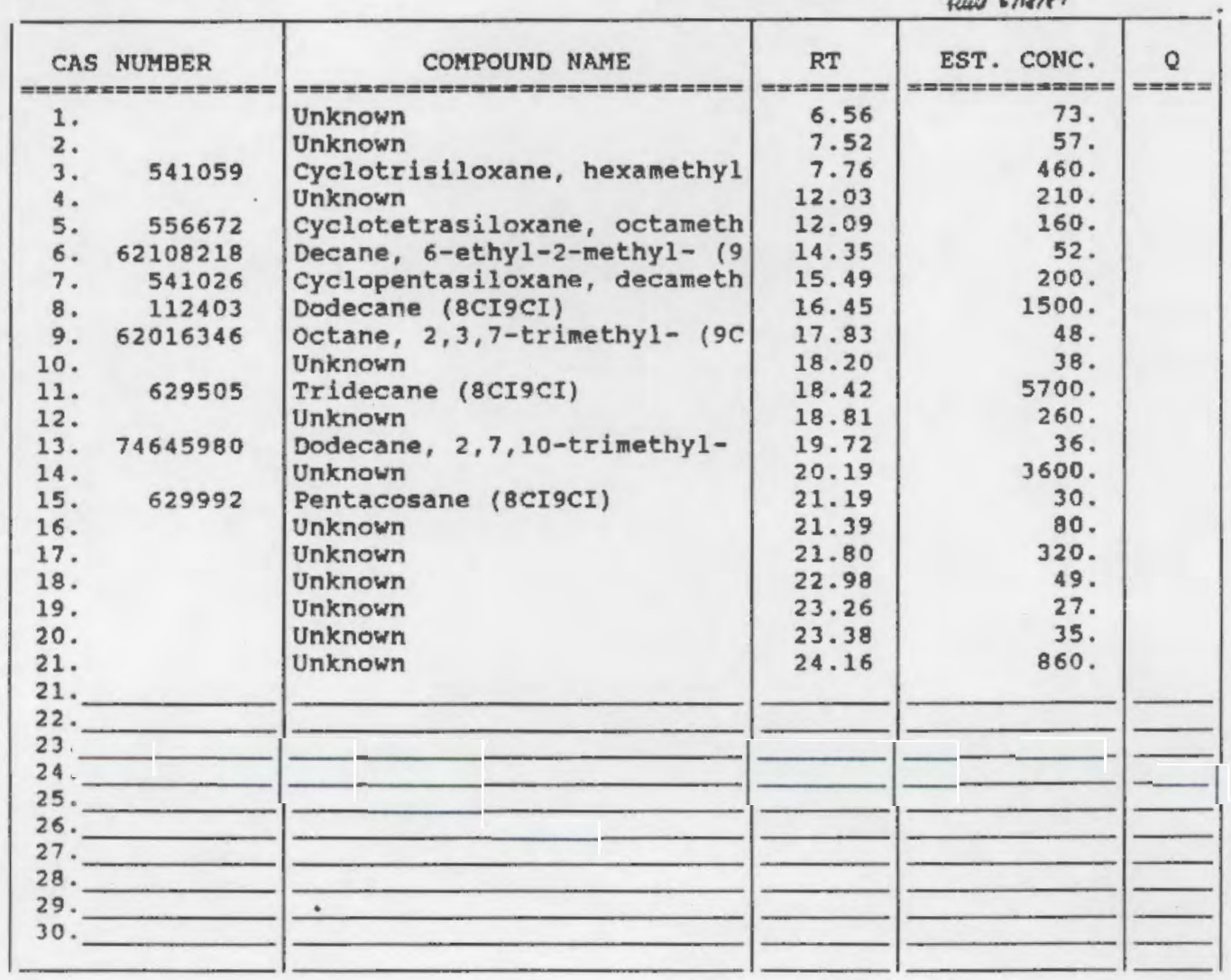

FIGURE 3.6. Tentatively Identified Compounds, Unacidified Sample 



\subsection{RADIONUCLIDE ANALYSIS}

Radionuclide analyses were performed on fused and dissolved samples from SST $105-C$ and 106- $C$. In addition to the radiochemical measurements requested in Table 1 of the Test Plan (see Appendix), Westinghouse Hanford Company (WHC) also asked that total alpha, total beta, and gamma energy analysis (GEA) be performed on both samples. The primary objective of the radionuclide measurements was to gather information relevant to the potential use of radionuclide ratioing and parent-daughter relationships for the estimation of radionuclides within samples. The first steps toward this objective were to determine if the analytical methods were adequate for analysis of SST samples and to identify those cases for which modifications or additional procedure development are needed. Satisfactory measurements were obtained for radioisotopes of $\mathrm{Am}, \mathrm{Cm}, \mathrm{Ni}, \mathrm{Pb}, \mathrm{Po}, \mathrm{Pu}, \mathrm{Ra}, \mathrm{Se}$, and $\mathrm{U}$. Further procedure development will be needed for radioisotopes of AC, Cs, Nb, $\mathrm{Pa}, \mathrm{Sm}, \mathrm{Th}$, and $\mathrm{Zr}$.

\subsection{TEST METHODS, RESULTS, AND DISCUSSION}

\subsubsection{Sample Fusion}

Weighed portions of SST archive samples $105-\mathrm{C}$ and $106-\mathrm{C}$ were fused by two different methods: 1) in $\mathrm{KOH}$ using a $\mathrm{Ni}$ crucible $(\mathrm{KOH} / \mathrm{Ni})$, as described in Figure 8 of the Test $\mathrm{Pl}$ an (see Appendix), and 2) in $\mathrm{Na}_{2} \mathrm{O}_{2}$ using a $\mathrm{Zr}$ crucible $\left(\mathrm{Na}_{2} \mathrm{O}_{2} / \mathrm{Zr}\right)$. Total alpha, total beta, and GEA measurements were made on acidified aliquots of dissolved samples from both fusion methods. Only the solutions resulting from the $\mathrm{KOH} / \mathrm{Ni}$ fusions were used for further radiochemistry.

\subsubsection{Sumnary of Radiochemical Measurements}

The results of total alpha, total beta, and GEA analyses on SST samples 105-C and 106-C are given in Table 4.1. Satisfactory agreement between duplicate analyses, using the $\mathrm{KOH} / \mathrm{Ni}$ and $\mathrm{Na}_{2} \mathrm{O}_{2} / \mathrm{Zr}$ fusion methods, was obtained for the total alpha and total beta results for sample 105-C. The total alpha and total beta results from the $\mathrm{Na}_{2} \mathrm{O}_{2} / \mathrm{Zr}$ fusion were somewhat higher than the results from the $\mathrm{KOH} / \mathrm{Ni}$ fusion. The ${ }^{137} \mathrm{Cs}$ results by GEA 
agreed well for the two fusion methods, and this isotope was by far the predominant gamma activity for both samples.

The radiochemistry results for all analyses except the $U$ isotopic analyses are presented in Table 4.2. The radioactivity is reported in units of $\mathrm{nCi} / \mathrm{g}$ except for the case of total $U$, which is given in units of $\mathrm{mg} / \mathrm{kg}$ for comparison with ICP fusion results. Table 4.2 also gives percent yield values for the duplicate analyses for those cases where a radioactive tracer was added. Some of the radiochemical measurements were not completed because of difficulties with the procedures, as will be discussed later.

The $U$ isotopic measurements were performed by isotope dilution mass spectrometry and are presented in Table 4.3. Each of the SST samples was analyzed directly and also analyzed spiked with $20 \mathrm{ng}$ of ${ }^{233} \mathrm{U}$.

\subsection{PROBLEM AREAS AND CORRECTIVE ACTIONS}

\subsubsection{Crucible Contamination}

Sample $105-\mathrm{C}$ was fused by both the $\mathrm{KOH} / \mathrm{Ni}$ and $\mathrm{Na}_{2} \mathrm{O}_{2} / \mathrm{Zr}$ methods. When the total alpha and GEA results were initially compared, the values were considerably different. Since no visible precipitate or undissolved particles were observed after acidification, the difference could not be attributed to incomplete dissolution of the sample. The problem was determined to be due to a contaminated crucible or volumetric flask. Therefore, the 105-C sample fusions were repeated using new crucibles and new glassware; the reproducibility of the total alpha and GEA values was then within acceptable limits, as reported in Table 4.1. This finding demonstrates that new equipment is required for the analysis of each sample.

Although $\mathrm{Ni}$ metal crucibles are inexpensive and easily obtained, they cannot be used when ${ }^{59} \mathrm{Ni}$ and ${ }^{83} \mathrm{Ni}$ measurements are required, since $\mathrm{Ni}$ dissolves into the fusion melt and absorbs the low-energy radiation emitted by these isotopes. Zr metal crucibles avoid this problem, but they are expensive, difficult to obtain in quantity, and $\mathrm{Zr}$ interferes with the radiochemical measurement of ${ }^{93} \mathrm{Zr}$ in a similar manner. If $\mathrm{Zr}$ crucibles are re-used, cross-contamination of samples could be a serious problem because large variations in activity level are anticipated among samples. 


\subsubsection{Cesium-137 Gamma Activity Leve1}

Although samples fused by the two methods yielded GEA results that agreed well for ${ }^{137} \mathrm{Cs}_{5}$, this was not true for other gamna activities in either sample. A method that would allow selective separation of Cs from the fusion melt solution is needed. This might reduce by orders of magnitude the $137 \mathrm{Cs}$ gamma activity and thereby improve the detection limit for other gamma emitters in SST samples.

\subsubsection{Procedures for Specific Radionuclides}

The two SST archive samples that have been analyzed to date may or may not be truly representative of SST waste tank sludge, and the chemical composition may even vary considerabiy within a given tank. Considerable adaptation of the various radiochemical procedures may be necessary in order to perform the desired measurements.

The current status of the procedures for each of the radionuclides in Table 1 of the Test PIan (see Appendix) will now be discussed.

Radionuclides ${ }^{227} \mathrm{AC}$

Rather than measuring the ${ }^{227} \mathrm{Ac}$ directly, the 18.7 -day daughter ${ }^{227} \mathrm{Th}$ was measured. This is a valid method for determining ${ }^{227}$ AC in SST samples since the parent and daughter will be in secular equilibrium. The two samples were run in duplicate, with ${ }^{228}$ Th added as a tracer for chemical yield estimation. Adequate separation from other alpha-emitters was achieved to allow calculation of upper limits to the ${ }^{227} \mathrm{Ac}$ activity for both $105-\mathrm{C}$ and 106-C samples. However, for one of the duplicates, Pu was not separated well enough to allow detection of ${ }^{227} \mathrm{Th}$. Therefore, further refinements to the separation procedure will need to be developed before this method can be considered reliable.

Radionuclides ${ }^{241} \mathrm{Am},{ }^{242} \mathrm{Am},{ }^{243} \mathrm{Am}$, and ${ }^{242} \mathrm{Cm}$

Due to their similar chemistry, Am and $\mathrm{Cm}$ were separated and purified together and measured by alpha energy analysis (AEA). Results for ${ }^{242}$ Am are not reported since this isotope cannot be easily measured by counting methods. Since measurement of ${ }^{243} \mathrm{Am}$ was requested, and this isotope is also used as the isotopic tracer in the PNL method, the procedure was performed 
twice, once with and once without the addition of ${ }^{243}$ An. If measurement of ${ }^{242} \mathrm{Am}$ is also required, a mass spectrometric analysis procedure will need to be used.

$\underline{\text { Radionuclides }{ }^{135} \mathrm{Cs} \text { and }{ }^{137} \mathrm{Cs}}$

Measurement of ${ }^{135} \mathrm{Cs}$ was unsuccessful because, with the procedure that was used, insufficient Cs was recovered for mass spectrometric analysis. The method involved selective retention of the $C_{S}$ on cation exchange resin, and it is likely that the high $K$ content of the solution resulting from the $\mathrm{KOH} / \mathrm{Ni}$ fusion prevented the $\mathrm{CS}$ from being retained. A procedure was developed that appeared to remove $K$ successfully from a synthetic SST sample. This involved precipitation of $K$ by addition of sodium tetraphenylborate, and was successful on the synthetic sample, but was not attempted on either of the archive samples. The effect of adding additional Na during the ion exchange separation of $C s$ was not studied. As an alternative, it may be more straightforward to use the existing procedure, but to separate the ${ }^{135} \mathrm{Cs}$ from an aliquot following acid digestion of the SST sample, since the $K$ content would be much lower. Further procedure development is needed.

$\underline{\text { Radionuclides }{ }^{59} \mathrm{Ni} \text { and }{ }^{63} \mathrm{Ni}}$

Analyses for these $\mathrm{Ni}$ radioisotopes are not possible if fusion is performed in a $\mathrm{Ni}$ metal crucible, as discussed earlier. An alternate method for measurement of ${ }^{59} \mathrm{Ni}$ may be ICP/MS. This might be simpler if the detection limit proved to be adequate, but the method would have poor sensitivity for ${ }^{63} \mathrm{Ni}$ due to its much shorter half-life. At this time PNL does not have the capability for measuring radioactive samples by ICP/MS, but this capability should be in place during the first half of Fy 1990.

$\underline{\text { Radionuclides }{ }^{94} \mathrm{Nb},{ }^{23} \mathrm{~Pa} \text {, and }{ }^{93} \mathrm{Zr}}$

No procedure currently exists for the analyses of these nuclides in SST matrices. Some procedure development work was performed based on ion exchange methods with sequential elution of $\mathrm{Zr}$, $\mathrm{Hb}$, and $\mathrm{Pa}$. Tracer studies look promising, but no measurements were attempted on SST samples. Additional procedure development will be necessary. 
$\underline{\text { Radionuclides } 21{ }^{20} \mathrm{~Pb},{ }^{226} \mathrm{Ra} \text {, and }{ }^{228} \mathrm{Ra}}$

Upper 1 imit values of $0.5 \mathrm{nCi} / \mathrm{g}$ for ${ }^{210} \mathrm{~Pb}$ and $5 \mathrm{nCi} / \mathrm{g}$ for ${ }^{228} \mathrm{Ra}$ are reported. However, significant interferences were observed from gamanaenitting species when the samples were counted. Since some of the anticipated SST samples are expected to contain high levels of gamma emitters, it will be necessary to modify these procedures in order to obtain better separation. Due to these interference problems, ${ }^{228}$ Ra measurements could not be performed.

An alternative for the measurement of ${ }^{210} \mathrm{~Pb}$ would be to measure the ingrowth of the daughter, ${ }^{210}$ Po. This would improve the sensitivity if a delay of approximately 100 days would be acceptable.

Radionuclide $210 \mathrm{Po}$

Less-than values of $0.002 \mathrm{nCi} / \mathrm{g}$ were calculated for ${ }^{210} \mathrm{Po}$.

Radionuclides ${ }^{238} \mathrm{Pu},{ }^{239} \mathrm{Pu},{ }^{248} \mathrm{Pu}$, and ${ }^{242} \mathrm{Pu}$

Results reported in Table 4.2 for ${ }^{238} \mathrm{Pu}$ and for ${ }^{239.240} \mathrm{Pu}$ were determined by AEA. The PNL procedure that was used requires ${ }^{242} \mathrm{Pu}$ as an isotopic tracer, so it was performed with and without the addition of the tracer. Less-than values were calculated for ${ }^{242} \mathrm{Pu}$ from the latter data. A mass spectrometric procedure is also available at PNL for the measurement of Pu isotopes. This method is more expensive, but is capable of greater accuracy and allows measurement of other Pu isotopes, such as ${ }^{241} \mathrm{Pu}$.

$\underline{\text { Radionuclide }{ }^{79} \mathrm{Se}}$

Results for ${ }^{79} \mathrm{Se}$ are reported in Table 4.2 . However, the existing PNL procedure is lengthy and has not given reliably good carrier recovery for the analysis of fused SST samples. Modifications currently being made to this method give improved radiochemical yield, and these modifications need to be tested on fused SST samples. Additional procedure development may be necessary.

This radionuclide is a good candidate for analys is by ICP/MS when the capability becomes available. 
Radionuclide ${ }^{151} \mathrm{Sm}$

This radionuclide is difficult to measure by radiochemical means because of its low-energy (21.4 keV) gamma emission. Adequate separation of any radionuclides that emit higher-energy gamma radiation is essential due to Compton background interference. Europium radioisotopes are of particular concern because they are difficult to separate from $\mathrm{Sm}$.

With a procedure using ${ }^{151}$ Sm radioactive tracer, $85^{\circ}$ of the Sm was recovered. A tracer study was then conducted using ${ }^{154} \mathrm{Eu}$ and various carriers to determine the degree of separation of Eu from Sm. The best separation achieved to date is $75 \%$ removal of Eu from the Sm fraction. Further procedure development will be necessary to verify that adequate separation from Eu is attainable.

Radionuclides ${ }^{228} \mathrm{Th},{ }^{238} \mathrm{Th}$, and ${ }^{232} \mathrm{Th}$

The chemistry adapted for SST sample analysis of Th isotopes was originally developed for the analysis of groundwater, where the only interfering species are due to naturally occurring radioactivity. In SST samples, fission products, including rare earth beta and ganma emitters, Pu, Am, and other actinides will be present. The adaptations that were investigated to cope with these interferences were not adequate to allow detection of Th alpha emission.

A revised radiochemistry scheme is recommended based on removal of Pu by solvent extraction after reduction to the +3 oxidation state. Several such solvent extraction systems exist. An optimum system should be chosen after consideration of the radionuclides expected to be present in SST samples. Additional methods development will be necessary for measurement of Th isotopes.

Radionuclides ${ }^{233} U,{ }^{234} U,{ }^{235} U,{ }^{238} U$, and ${ }^{238} \mathrm{U}$

An isotope dilution, mass spectrometric procedure was used, with addi$t$ ion of a ${ }^{233} \mathrm{U}$ spike. Since analysis for ${ }^{233} \mathrm{U}$ was requested, the procedure was also repeated without addition of the spike. At one stage of the procedure, unleached glassware was used, so there is the possibility of some sample contamination with natural $U$ leached from the glass. 
Total U

No problems were encountered in the laser fluorometric method for total $U$ analysis. For SST sample $105-C$, the $U$ result by ICP was $10,500 \mathrm{mg} / \mathrm{kg}$ versus a result of $8,200 \mathrm{mg} / \mathrm{kg}$ by the laser method. No ICP result was obtained for SST sample 106-C.

\subsection{CONCLUSIONS RELATED TO TEST PLAN OBJECTIVES}

4.3.1 To Gather Information Relevant to the Potential Use of Radionuclide Ratioing and Parent-Daughter Relationships for the Estimation of Radionuclides within Samples

Because of the large amount of procedure development and modification required for radiochemical analyses of SST samples, few conclusions could be drawn related to the primary objective. Additional procedure development will be required for the measurement of ${ }^{94} \mathrm{Nb},{ }^{231} \mathrm{~Pa},{ }^{227} \mathrm{AC},{ }^{79} \mathrm{Se},{ }^{93} \mathrm{Zr}$, ${ }^{229} \mathrm{Th},{ }^{236} \mathrm{Th},{ }^{232} \mathrm{Th},{ }^{242} \mathrm{Am},{ }^{151} \mathrm{Sm},{ }^{216} \mathrm{~Pb},{ }^{220} \mathrm{Ra}$, and ${ }^{228} \mathrm{Ra}$. Modifications to the existing procedure will be necessary for ${ }^{136} \mathrm{Cs}_{5}$. Approved procedures are not in place for determination of most of the radionuclides listed in Table 1 of the Test Plan (see Appendix) for SST matrices.

TABLE 4.1. Total Alpha, Total Beta, and GEA Results for SST Samples 105-C and 106-C

Radionuclide

Total a

Total $\beta$ as
Sr/90Y

GEA $\begin{array}{r}{ }^{137} \mathrm{Cs} \\ { }_{86}^{6} \mathrm{Co} \\ 154 \mathrm{Eu} \\ 125 \mathrm{Sb}\end{array}$

$\frac{\mathrm{KOH} / \mathrm{Ni}}{\mathrm{Na}}$

$1.17 \mathrm{E} 3$

$1.15 \mathrm{E} 3$

3.63E6

3.89E6

$3.02 \mathrm{E} 5$

$3.73 \mathrm{E} 2$

$2.68 \mathrm{E} 3$
1. $40 \mathrm{E} 3$

$1.30 \mathrm{E} 3$

$3.89 \mathrm{E} 6$

4.03E6

$3.05 \mathrm{E} 5$

$6.17 \mathrm{E} 2$

$3.82 \mathrm{E} 3$

$\frac{\text { Sample } 106-\mathrm{C}(\mathrm{nCi} / \mathrm{g})}{\mathrm{KOH} / \mathrm{Ni}}$

4.13E3

3.99E3

8.83E6

8.56E6

8.56E6

8.15E6

8. 34E6

4.82E5

1.16E3

5. $40 \mathrm{E} 3$
5.04E5

$7.88 \mathrm{E} 2$

$7.97 \mathrm{E} 3$

$5.68 \mathrm{E} 3$ 
TABLE 4.2. Radiochemical Measurements and Tracer Yields for SST Samples 105-C and 106-C

\begin{tabular}{|c|c|c|c|c|}
\hline \multirow[b]{2}{*}{ Radionuclide } & \multicolumn{2}{|c|}{ Sample 105-C } & \multicolumn{2}{|c|}{ Sample 106-C } \\
\hline & $\begin{array}{l}\text { Activity } \\
(n \mathrm{C} i / \mathrm{g})\end{array}$ & $\begin{array}{l}\text { Yield } \\
(\%) \\
\end{array}$ & $\begin{array}{l}\text { Activity } \\
\text { (nCi/g) }\end{array}$ & $\begin{array}{c}\text { Yield } \\
\left(\frac{o}{6}\right) \\
\end{array}$ \\
\hline $227 \mathrm{AC}$ & $<1.4$ & $1-2$ & $<0.9$ & $1-2$ \\
\hline $2{ }^{4} \mathrm{Am}$ & $962 \pm 38$ & 22,27 & $2824 \pm 98$ & 42,26 \\
\hline${ }^{243} \mathrm{Am}$ & $4.9 \pm 1.3$ & $"$ & $19.2 \pm 2.1$ & " \\
\hline${ }^{242} \mathrm{Cm}$ & $3.0 \pm 0.3$ & $"$ & $10.5 \pm 0.7$ & $"$ \\
\hline $244 \mathrm{~cm}$ & $29.5 \pm 1.4$ & $"$ & $129 \pm 5$ & $"$ \\
\hline${ }^{238} \mathrm{Pu}$ & $48 \pm 5$ & 62,72 & $422 \pm 11$ & 51,44 \\
\hline${ }^{239} \mathrm{Pu}$ & $747 \pm 126$ & $"$ & $2340 \pm 57$ & $"$ \\
\hline $242 \mathrm{Pu}$ & $<0.2$ & $"$ & $<0.4$ & $"$ \\
\hline${ }^{135} \mathrm{Cs}$ & & & & \\
\hline${ }^{59} \mathrm{Ni}$ & $128 \pm 5$ & 61,76 & $68 \pm 14$ & 87,88 \\
\hline${ }^{63} \mathrm{Ni}$ & $12885 \pm 1804$ & $"$ & $7770 \pm 1508$ & $"$ \\
\hline $94 \mathrm{Nb}$ & & & & \\
\hline $23^{1} \mathrm{~Pa}$ & & & & \\
\hline $210^{\circ b}$ & $<0.2$ & & $<0.3$ & \\
\hline $21 \% \mathrm{Po}$ & $<.002$ & & $<.002$ & \\
\hline${ }^{228} \mathrm{Ra}$ & $<5 ?$ & & $<5 ?$ & \\
\hline${ }^{228} \mathrm{Ra}$ & & & & \\
\hline${ }^{70} \mathrm{Se}$ & $2.5,2.5(a)$ & & $0.95,0.53(a)$ & \\
\hline $151_{\text {S月 }}$ & & & & \\
\hline
\end{tabular}

Th Isotopes

Total U (mg/kg)

8200

98.8

944

101.3

(a) Replicate analysis. 
IABLE 4.3. Uranium Isotopic Analyses on SST Samples 105-C and 106-C Sample 105-C Sample 106-C

U With ${ }^{233} U(a)$ Without ${ }^{233} U$

Mass

Atom \% Atom $\%$

233

0.02264

0.00719

With ${ }^{233} \mathrm{u}(\mathrm{a})$ Wi thout ${ }^{233} \mathrm{U}$

234

0.00510

0.00913 Atom

Atom $\%$

235

0.65665

0.65070

0.19040

0.00067

236

0.01247

0.02243

0.00615

0.00558

238

99.30313

99.31055

0.64334

0.65239

0.01942

0.01157

(a) Addition of $20 \mathrm{ng}$ of ${ }^{233} \mathrm{U}$. 



\subsection{NORMAL PARAFFIN HYDROCARBON STUDIES}

Normal paraffin hydrocarbon is used as part of the core sampling process. Therefore, it is important to know whether inorganic anions and cations and radionuclides are soluble in this medium. To evaluate solubility, a slurry consisting of SST sample 106-C and SST sample 102-AX supernate was contacted with NPH for a period of $48 \mathrm{~h}$. An aliquot of NPH was removed for radiochemical analysis. The remaining NPH was then back-extracted with water and $1 \mathrm{M}$ nitric acid and the inorganic species determined by ICP.

\subsection{TEST METHODS, RESULTS, ANO SIGNIFICANCE}

\subsubsection{Experimental}

A slurry consisting of $14.4 \mathrm{~g}$ of solid sample from SST 106-C and $26.8 \mathrm{~g}$ of SST sample 102-AX supernate was prepared and contacted with NPH in accordance with Figure 10 of the Test Plan (see Appendix). After centrifuging, a $10 \mathrm{~mL}$ aliquot of the NPH phase was removed from the hot cell for GEA analysis. The remaining NPH was then contacted with an equal volume of water, and an aliquot of the aqueous phase was analyzed for inorganic species. The NPH was then contacted with an equal volume of $1 \mathrm{M}$ nitric acid, and the inorganic species were measured in the acid phase. NPH blank solutions were generated by contacting virgin NPH with water and with $1 \mathrm{M}$ nitric acid.

\subsubsection{ICP Inorganic Constituent Solubility Results}

The primary inorganic constituents found in the $\mathrm{NPH}$ were $\mathrm{P}, \mathrm{Na}$, and $\mathrm{NO}_{3}$, as shown in Table 5.1. The NPH blanks were run to determine what was extractable from the NPH itself. Upon evaluation of the data, it is obvious that the $P$ is not all in the form of phosphate ions. It is suspected that it is present as an organo-phosphorus compound that was extracted from the SST sample. The high $\mathrm{Na}$ and $\mathrm{NO}_{3}$ content in the extracts correlates with the high $\mathrm{Na}$ and $\mathrm{NO}_{3} / \mathrm{NO}_{2}$ content of the SST sample. 


\subsubsection{Radionuclide Solubility Results}

Results of the radiochemical measurements on the NPH in units of $\mathrm{nCi} / \mathrm{mL}$ are given in Table 5.2. No alpha, beta, or GEA analyses of the combined 106-C and 102-AX supernate slurry were performed; therefore, no direct quantitative determination of the extraction of radionuclides into NPH could be calculated. However, these counting measurements were performed for SST sample 106-C and are presented in Table 4.1. By comparison of Tables 4.1 and 5.2 , the level of extraction of radionuclides into NPH is considered to be insignificant. The percent of total alpha and total beta activity extracted was $0.004 \%$ and $0.0012 \%$, respectively. From the GEA data, the percentages of ${ }^{137} \mathrm{Cs},{ }^{60} \mathrm{Co}$, and ${ }^{154} \mathrm{Eu}$ activity extracted were $0.026 \%, 0.076 \%$, and $0.003 \%$, respectively.

\subsection{CONCLUSIONS RELATED TO TEST PLAN OBJECTIVES}

5.2.1 To Determine the Solubility of Inorganic and Radiochemical Ions in NPH

As discussed previously, most of the measured ions showed no significant difference between the NPH/SST and the NPH/blank samples. The higher B and Si in the NPH/SST sample is probably due to radiation damage to the borosilicate glass vessel used for extraction. The high $\mathrm{Na}$ and $\mathrm{K}$ are probably physical carryover from the synthetic sludge. The source of the $P$ is most likely from a degradation product of tri-butylphosphate (TBP). Even though the ICP, IC, and radiochemical results for this archive composite indicate low solubility of the measured ions in NPH, it may be prudent to confirm these results on future core samples. 
TABLE 5.1. ICP and IC Measurements for NPH Equilibrated with Composite of SST Samples 106-C and 102-AX

\begin{tabular}{|c|c|c|c|c|c|c|}
\hline \multirow{2}{*}{$\begin{array}{c}\text { ICP } \\
\text { Elements }\end{array}$} & \multicolumn{3}{|c|}{ NPH Blank $(\mu \mathrm{g} / \mathrm{g})$} & \multicolumn{3}{|c|}{ NPH SST Sample $(\mu \mathrm{g} / \mathrm{g})$} \\
\hline & $\mathrm{H}_{2} \mathrm{O}$ & $\mathrm{HNO}_{3}$ & Total & $\mathrm{H}_{2} \mathrm{O}$ & $\mathrm{HNO}_{3}$ & Total \\
\hline $\mathrm{Ag}$ & 0.015 & 0.031 & 0.046 & 0.161 & 0.058 & 0.219 \\
\hline As & 0.16 & 0.15 & 0.31 & 0.18 & 0.15 & $0.32(a)$ \\
\hline B & 0.005 & 0.026 & 0.031 & 0.405 & 0.080 & 0.485 \\
\hline $\mathrm{Ba}$ & & 0.013 & 0.013 & 0.019 & 0.007 & $0.026(a)$ \\
\hline $\mathrm{Ca}$ & 0.425 & 0.243 & 0.668 & 0.449 & 0.328 & $0.777(a)$ \\
\hline$c d$ & 0.008 & 0.014 & 0.022 & 0.019 & 0.014 & $0.033(a)$ \\
\hline $\mathrm{Ce}$ & & 0.101 & 0.101 & & 0.101 & 0.101 (a) \\
\hline Co & 0.013 & 0.024 & 0.037 & 0.031 & 0.022 & 0.053 \\
\hline $\mathrm{Cr}$ & & 0.014 & 0.014 & 0.020 & 0.014 & $0.034(a)$ \\
\hline $\mathrm{Cu}$ & 0.012 & 0.018 & 0.030 & 0.034 & 0.021 & 0.055 \\
\hline $\mathrm{Fe}$ & & 0.040 & 0.040 & 0.018 & $\begin{array}{l}0.035 \\
0.309\end{array}$ & $0.053(\mathrm{a})$ \\
\hline $\begin{array}{l}K \\
M a\end{array}$ & & 0.177 & 0.18 & 0.714 & 0.309 & $\begin{array}{l}1.02 \\
0.036\end{array}$ \\
\hline$M n$ & & & & $\begin{array}{l}0.037 \\
0.037\end{array}$ & & 0.037 \\
\hline $\mathrm{Na}$ & 3.47 & 0.812 & 4.3 & 162 & 15.4 & 177 \\
\hline $\mathrm{Ni}$ & & & & & 0.054 & 0.054 \\
\hline $\mathrm{P}$ & 6.42 & 7.93 & 14.4 & 170 & 11.9 & 182 \\
\hline $\mathrm{Pb}$ & & 0.080 & 0.08 & 0.055 & 0.077 & $0.13(a)$ \\
\hline Sb & 0.221 & 0.30 & 0.52 & 0.365 & 0.337 & $0.70(a)$ \\
\hline $\mathrm{Se}$ & 0.271 & 0.335 & 0.60 & 0.301 & 0.369 & $0.67(a)$ \\
\hline $\mathrm{Si}$ & 0.033 & 0.085 & 0.12 & 2.14 & 0.445 & 2.59 \\
\hline $\mathrm{TI}$ & 0.32 & 0.43 & 0.75 & 0.35 & 0.47 & 0.82 (a) \\
\hline U & 0.69 & 1.01 & 1.70 & 0.75 & 1.11 & $1.86(\mathrm{a})$ \\
\hline V & 0.016 & 0.022 & 0.038 & 0.017 & 0.020 & 0.037 (a) \\
\hline $\mathrm{Zn}$ & 0.013 & 0.034 & 0.047 & 0.012 & 0.032 & 0.042 (a) \\
\hline $2 r$ & & 0.033 & 0.033 & 0.012 & & $0.012(a)$ \\
\hline
\end{tabular}

Anions
$\mathrm{F}$
$<0.08$
$<0.08(a)$
$0.4(a)$
$\mathrm{NO}_{2} \quad 0.12$
8.1
$\mathrm{NO}_{3}-2.8$
37.9
$4.2(a)$
$4.4(a)$

(a) Elements or anions which show no significant difference between the sample and the blank. 
TABLE 5.2. Total Alpha, Total Beta, and GEA Results on NPH Equilibrated with Composite of SST Samples 106-C and 102-AX

\begin{tabular}{|c|c|}
\hline $\begin{array}{c}\text { Gamma } \\
\text { Energy Analys is }\end{array}$ & $(\mathrm{nCi} / \mathrm{mL})$ \\
\hline${ }^{137} \mathrm{Cs}$ & 127.0 \\
\hline${ }^{80} \mathrm{Co}$ & 0.88 \\
\hline $154 \mathrm{Eu}$ & 0.17 \\
\hline Total Alpha & Total Beta \\
\hline & $\left(\right.$ as $\left.{ }^{90} \mathrm{Sr}-{ }^{90} \mathrm{Y}\right)$ \\
\hline 0.18 & 106.0 \\
\hline
\end{tabular}

5.4 


\subsection{RADIOLOGICAL EXPOSURE STUDY}

Estimates of radiological exposure were made based on radiation measurement at contact and at a distance of about $3 \mathrm{ft}$ for the sample aliquots removed from the hot cell for the inorganic, organic, and radiochenical analyses. Estimates were also made of the amount of time that the analyst would be in the contact with the sample when performing each of the various procedures. Thus, it is possible to obtain information on the radiation exposure that would be received in performing the various analyses.

\subsection{TEST METHODS, RESULTS, AND DISCUSSION}

\subsubsection{Experimental}

The analyst recorded the volume of sample used in each procedure, and estimated the time in contact with the sample. These data were entered into radiation exposure study forms for each procedure. Exposure was held to a minimum by use of ALARA (As Low As Reasonable Achievable) sample handling methods.

\subsubsection{Exposure Summary}

The SST samples 102-C and 105-C were much lower in activity than SST sample 106-C. No significant exposure to personnel was received in performing any of the measurements. The data from the radiation exposure study forms were used to summarize the radiation exposure received by the analyst and are presented in Tables 6.1 and 6.2 .

\subsection{CONCLUSIONS RELATED TO TEST PLAN OBJECTIVES}

6.2.1 To gather information on the radiological exposure and time durations required in utilizing the various methods.

As discussed previously, for the specific analytical methods used in this study no significant exposure to personnel was received in performing any of the measurements. Use of other methods or larger sample sizes could increase exposures. 
TABLE 6.1. Exposure Data Summary for Radiochemical Separations

Sample Procedure Used

\begin{tabular}{|c|c|c|c|c|}
\hline $\begin{array}{l}\text { Volume Removed } \\
\text { from Hot Cell } \\
\text { (mL) }\end{array}$ & $\begin{array}{l}\text { Exposure } \\
\text { Contact } \\
\text { (mR/hr) }\end{array}$ & $\begin{array}{l}\text { Leve] } \\
\begin{array}{l}\text { feet } \\
(\mathrm{mR} / \mathrm{hr})\end{array}\end{array}$ & $\begin{array}{l}\text { Volume Used } \\
\text { for Analys is } \\
(\mathrm{mL})\end{array}$ & $\begin{array}{l}\text { Time in Contact } \\
\text { with Sample (est.) } \\
\text { (min) }\end{array}$ \\
\hline
\end{tabular}

Sample

$105-\mathrm{C}$

Ni fusion,

5

5

$<1$

2

20

Radiochemical

separation

for Ac

Sample

106-C

Nifusion,

5

25

2.5

1

10

Radiochemical

separation

for $A C$

Sample

105-C

Zr fusion,

7

$<1$

4.2

65

Radiochemical

separations

for $\mathrm{Pu}$, Am,

$\mathrm{Ni}, \mathrm{Po}, \mathrm{Pb}, \mathrm{Ra}$

Sample

106-C

Zr fusion,

5

30

3

4.2

65

Radiochemical

separations

for $\mathrm{Pu}, \mathrm{Am}$,

$\mathrm{Ni}, \mathrm{Po}, \mathrm{Pb}, \mathrm{Ra}$

Sample

105-C

Zr fusion,

50

7

$<1$

20

60

Radiochemical

separations

for $\mathrm{Po}, \mathrm{Pb}$,

$U$, Th

Sample

106-C

Zr fusion,

Radiochemical

separations

for $\mathrm{Po}, \mathrm{Pb}, \mathrm{U}$, Th

50

30

3

20

60 
IABLE 6.2. Exposure Data Sumnary for Inorganic Analyses

Sample Procedure Used

\begin{tabular}{|c|c|c|c|}
\hline $\begin{array}{l}\text { Volume Removed } \\
\text { from Hot Cell }\end{array}$ & $\frac{\text { Exposure Level }}{\text { Contact } 3 \text { feet }}$ & $\begin{array}{l}\text { Volume Used } \\
\text { for Analys is }\end{array}$ & $\begin{array}{l}\text { Time in Contact } \\
\text { with Sample (est.) }\end{array}$ \\
\hline
\end{tabular}

Sample

$102-\mathrm{C}$

100

$40-3$

$<0.5$

100

5

EPricity,

Sample \#1,

ICP al iquot

Sample

$102-C$

EP Toxicity,

100

$35-2.5$

$<0.5$

100

5

Sample \#2,

ICP al iquot

Sample

102-C

10

$4.5-<0.5<0.5$

10

5

KOH Fusion

Sample

102-C

$\mathrm{Na}_{2} \mathrm{O}_{2}$ Fusion

10

$4.0-<0.5<0.5$

10

5

Sample

102-C

Fused Solids

10

$1.0-<0.5<0.5$

10

5

from Acid

Digestion,

Samp le \#1

Sample

102-C

Fused Solids

10

$<0.5-<0.5<0.5$

10

5

from Acid

Digestion,

Sample \#2 

APPENDIX

TEST PLAN FOR ANALYSIS OF ARCHIVE SAMPLES OF SINGLE-SHELL TANK SAMPLES PROVIDED BY WESTINGHOUSE HANFORD COMPANY 
REVISION 0

Approval Date 2-1-89

SINGLE-SHELL TANK TECHNOLOGY SUPPORT PROGRAM

TEST PLAN FOR ANALYSIS OF ARCHIVE SAMPLES OF

SINGLE-SHELL TANK SAMPLES PROVIDED BY WESTINGHOUSE HANFORD COMPANY

PROJECT 13924

WBS 8930

Plrand Prane-

PRINCIPAL INVESTIGATOR F. T. HARA

$\frac{1 / 31 / 89}{\text { DATE }}$

Halle Peume

MANAGER, CHEMISTRY \& ANALYSIS SECTION W. C. WEIMER

$1 / 31 / 89$

Rolent S Wegeng

PROJECT MANAGER R. S. MEGENG

$1-31-89$

DATE

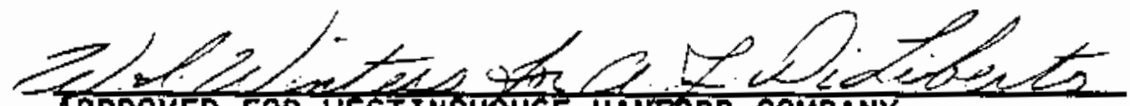

APPROVED FOR WESTINGWOUSE HAVEORD COMPANY

saper atered convelwation

$\frac{2 / 1 / 87}{\text { DATE }}$ 
REVISION 0

Approval Date 2-1-89

TABLE OF CONTENTS

\section{Page}

I. INTRODUCTION 1

II. SCOPE AND OBJECTIVES 1

III. TEST METHOOS 2

Sample Preparation

Percent Solids

Water Leach

EP Tox

Acid Digestion

Mercury Analysis

Total Cyanide

Fusion Procedure/Radionuclides

Semivolatile Organic

Nomal Paraffin Hydrocarbon

2

2

$\begin{array}{ll}\text { IV. PRODUCTS } & 18\end{array}$

$\begin{array}{ll}\text { V. PRINCIPAL INVESTIGATOR } & 18\end{array}$

VI. GENERAL TEST PROGRAM PREREQUISITES \& REQUIREMENTS 18

$\begin{array}{ll}\text { Prerequisites } & 18\end{array}$

Personnel Qualifications 18

Safety 18

M\&TE 19

$\begin{array}{ll}\text { Pretest Verification } & 19\end{array}$

$\begin{array}{ll}\text { Requirements } & 19\end{array}$

Expected Results/Acceptance Criteria 19

Documentation and Data Package Preparation 19

Change Control and Test Modifications 20

Data Review \& Evaluation 20

Instructions \& Procedures 21

Hazardous Materiais Management 21

Waste Disposal Plan 21

FIGURES

TABLE 
REVISION 0

Approval Oate $2-1 \div 89$

\section{LIST OF FIGURES}

Number

Title

Page

Figure 1 Single Shell Tank - Flow Sheet for Sample Preparation

Figure 2 Single Shell Tank - Flow Sheet for Percent Solid

Determination per CLP Method Part F, page D-84

Figure 3 Single Shell Tank - Flow Sheet for Water Leach per PNL Test Procedure WWVP-1

Figure 4 Single Shell Tank - Flow Sheet for Mofified EP Tox per SOw 846 Methods 1320

Figure 5 Single Shell Tank - Flow Sheet for Acid Digestion per SOW 787 Page $0-4$

Figure 6 Single Shell Tank - Flow Sheet for Mercury Analys is by Cold Vapor Technique per SOw 787 Modified Method 245.5

Figure 7 Single Shell Tank - Flow Sheet for Total Cyanide in in Sediment per EPA Method 9010 and CLP Method 335.2

Figure 8 Single Shell Tank - Flow Sheet for $\mathrm{KOH}$ Fusion Procedure

Figure 9 Single Shell Tank - Flow Sheet for Senivolatile Organic Method per SOW 787 Section $0-2 /$ SV

Figure 10 Single Shell Tank - Flow Sheet for NPH Extractability Studies

\section{LIST OF TABLES}

Table 1 Radiochenical Measurements and Methods 
REVISION 0

Approval Date 2-1-89

TEST PLAN FOR ANALYSIS OF ARCHIVE SST SAMPLES

\section{INTROOUCTION}

The purpose of this test plan is to describe the work and methods to be used for the analyses of archived Single-Shell Tank (SST) samples within PNL analytical laboratories. This work will be performed as part of PNL's SST Technology Support Program, Project 13924, under the Analytical Chenistry Task (WBS 8930).

\section{TEST SCOPE AND OBJECTIVES}

Hork conducted under this test plan will consist of analyses of archive samples from SSTs 102-C, 105-C, and 106-C. As described in Section III. organic, inorganic, and the EP Tox analyses will be performed on the sample from SST 102-C and the radiochemical analyses on the sample from SST 105-C. The normal paraffin hydrocarbon test will utilize the sample from SST 106-C. The objectives of these tests are:

- To determine if there are problems with employing the various analytical methods on the test samples,

- To determine if the ICP has sufficient sensitivity for the analysis of EP Tox metal ions (excluding mercury, which will be analyzed by the cold vapor method),

- To determine which of the 22 EPA pollutant metal ions can be determined by ICP analysis,

- To determine if mercury can be determined by the cold vapor (CV) method,

- To determine whether the EPA Semivolatile Organic method can be employed on SST samples

- To determine solubility of inorganic and radiochemical ions in NPH

- To gather information on the radiological exposure and time durations required in utilizing the various methods, and

- To gather information relevant to the potential use of radionuclide ratioing and parent-daughter relationships for the estimation of radionuclides within samples.

The last two objectives support the evaluations which are being performed under the Alternative Techniques Task (WBS 8970). 
REVISION 0

Approval Date 2-1̄-89

\section{TEST METHOOS}

\section{Sample Preparation}

Sample preparation to establish homogeneity of the sample is outlined on Figure 1. The method of grinding and sieving the sample was selected since the previous archive SST sample was essentialily a dry solid. A small portion of the previous archive sample showed some caking but these clumps were easily ground with a mortar and pestle and sieved.

\section{Percent Solids}

The percent solids determination method is outlined on Figure 2 .

\section{Nater Leach}

The water leach procedure is outlined on Figure 3 . The spike containing the anions is added at the beginning of the sample preparation scheme while the spike containing the cations is added after filtering the sample since the cation spike is prepared in an acid matrix. After filtering the sample, a $10 \mathrm{ml}$ aliquot of the three samples and the blank used for IC, TOC, and TIC analyses are removed from the hot cell. The exposure level of the IC samples will be determined at this time. If the exposure level of the IC samples is low enough to safely work with the sample outside of the hot cell, the samples for ICP analyses will also be removed from the hot cell and subsequent sample preparation done in an open faced hood. The concentrations of the various elements in the anion and cation spikes are selected based on the analyses of previous SST samples and the recomended CLP spiking levels in SON 787 page $E-10$. If the ICP analysis detects a significant concentration of water soluble chromium (greater than $1 \mathrm{ug} / \mathrm{ml}$ ), an aliquot of the sample will be analyzed spectrophotometrically for chromium VI.

\section{EP Tox}

The modified EP Tox method is outlined on Figure 4. The spiking level for the EP Tox method was selected at the lower limit of the dangerous waste (DH) maximum concentration limits. After filtering the samples, $10 \mathrm{ml}$ aliquot of the two samples and the blank are removed for the cold vapor mercury analyses. The exposure level of the two aliquot will be determined when the samples are removed from the hot cell. If the exposure level of the $\mathrm{Hg}$ samples is sufficiently low, the $15 \mathrm{ml}$ aliquot for ICP analys is will be removed from the hot cells and the subsequent sample preparation will be done in an open faced hood. 
REVISION 0

Approvat Date 2-1-89

FIGURE 1

SINGLE SHELL TANK

SAMPLE PREPARATION

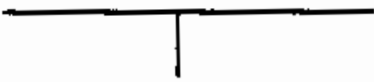

GRIND

(Coor Porcelain Mortor)

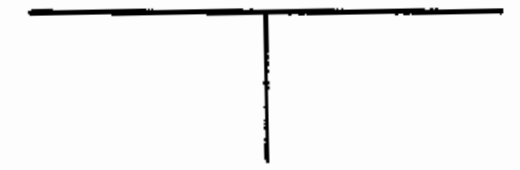

MIX, BLEND, SIEVE (0.7 $\mathrm{mm})$

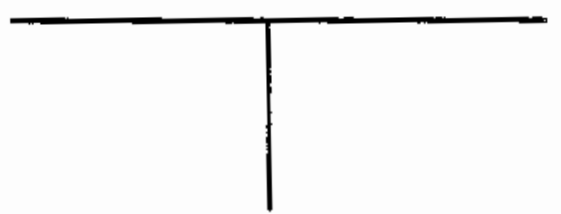

RETURN TO SAMPLE BOTTLE

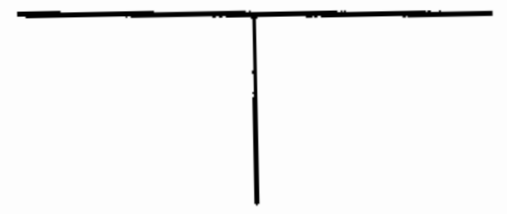

WEIGH SUBSAMPLES

As Shown on the Following Sheets 


\section{FIGURE 2}

\section{SINGLE SHELL TANK}

Percent Solid Determination per CLP Method Part F page D-84
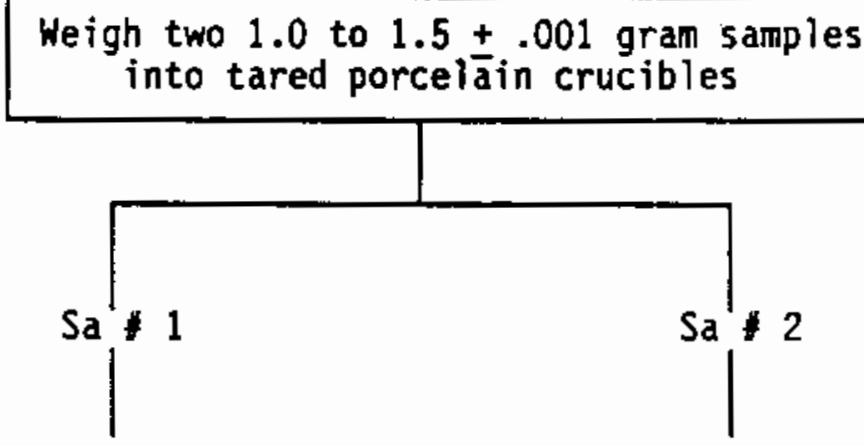

1. Place the crucibles into a drying oven maintained at 103-1050 C.

2. Ory the sample overnight (12-24 hours) but no longer than 24 hours.

3. Cool the crucibles in a dessicator and weigh the samples to the nearest $0.001 \mathrm{~g}$.

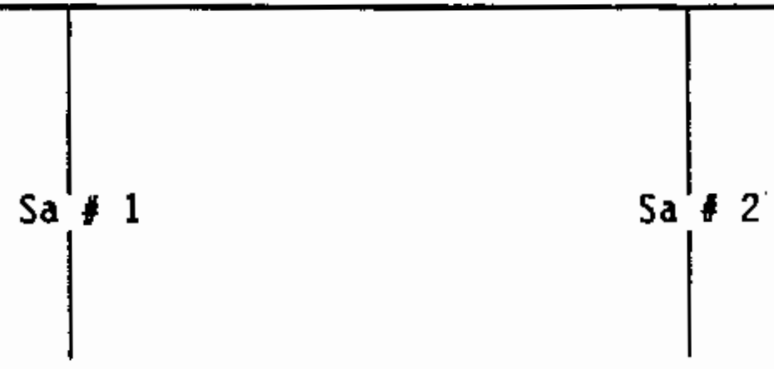




\section{FIGURE 3}

\section{SINGLE SHELL TANK}

Water Leach

per PNL Test Procedure HWVP-1

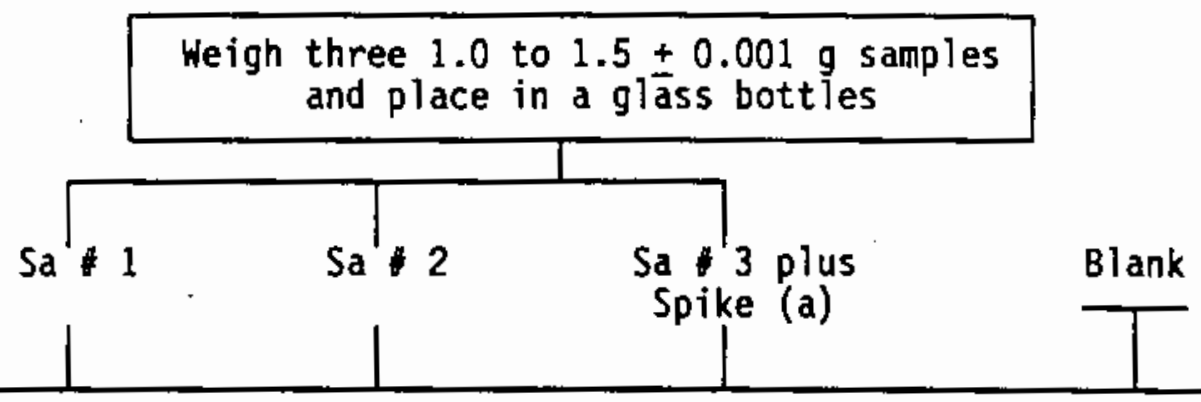

1. Add $100 \mathrm{ml}$ of DIH to the sample bottles. On the spike sample, add $90 \mathrm{mi}$ of DIW and $10 \mathrm{ml}$ of the spike solution (a).

2. Cap the bottles and place in an ultrasonic bath for at least one hour.

3. Let the solution stand overnight and filter the supernate through 0.45 micron filter.

4. For IC, TOC and TIC, remove $10 \mathrm{ml}$ of the filtered solutions into approriate sample vials.

5. For ICP analysis, pipet $15 \mathrm{ml}$ of each of the filtered solution into tared glass vial containing $0.4 \mathrm{ml}$ of $1: 1 \mathrm{HCl}$. The third sample for ICP analyses is spike with soln (b).

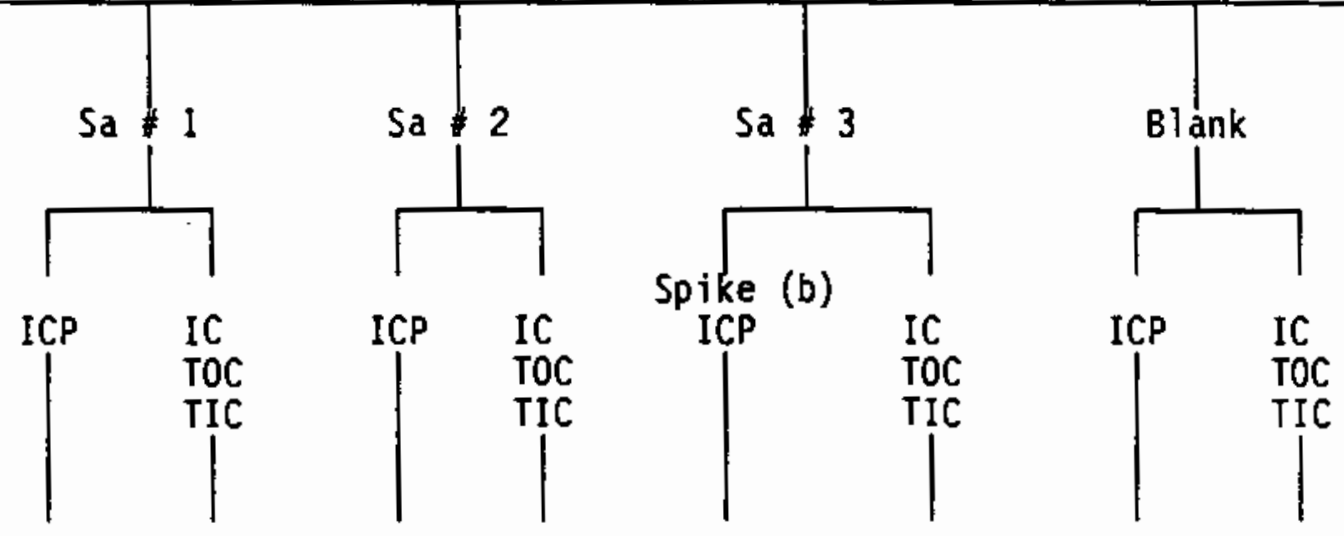

(a) Anion spike to contain 20 ug F-, 20 ug $\mathrm{C}_{\mathrm{I}}-, 100 \mathrm{ug} \mathrm{N03-,} 1300 \mathrm{ug} \mathrm{N02-}$, $100 \mathrm{ug} \mathrm{PO4}-3$, and 300 ug $\mathrm{SO}_{4-2}$ per $10 \mathrm{ml}$ of sample.

(b) Cation spike to contain 10 ug A1, 10 ug Ba, 10 ug Bi, 5 ug Cd, 10 ug Ca, 5 ug $\mathrm{Co}, 10$ ug Fe, 10 ug $\mathrm{Pb}, 10 \mathrm{ug} \mathrm{Mn}, 10$ ug $\mathrm{V}, 100$ ug $P, 40$ ug $\mathrm{K}, 10$ ug Zr, 10 ug Cu, 10 ug Sb, 10 ug As, 0.5 ug Be, 20 ug Se, 20 ug Ti, 10 ug V and $10 \mathrm{ug} \mathrm{Zn}$ per $10 \mathrm{ml}$ of sample. The second solution to contain $50 \mathrm{ug}$ $\mathrm{Cr}$ as $\mathrm{Cr}+6$ and 5 ug $\mathrm{Ag}$ per $10 \mathrm{ml}$ of sample.

(c) If spike recovery of anion sample 3 is not within limits of 75-125\% an aliquot of filtered solution from sample 2 will be spiked and analyzed. 
REVISION 0

FIGURE 4

Approval Date 2-1-89

Modified EP Tox per SOH 846

Method 1310

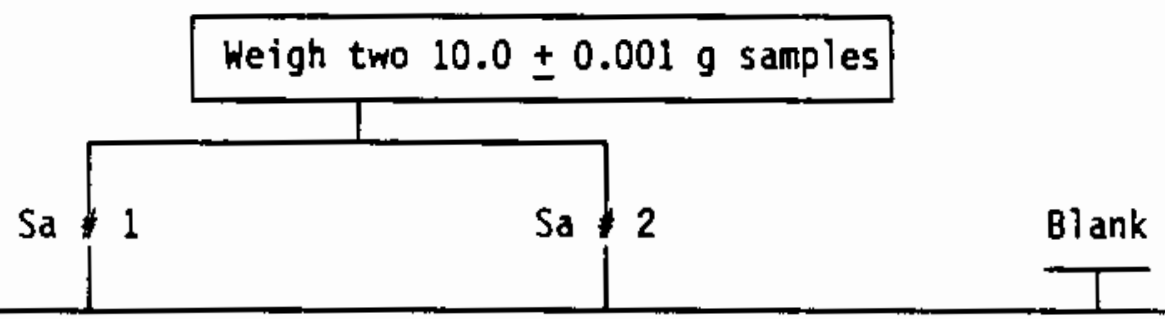

1. Add $160 \mathrm{ml}$ of DIW. Agitate sample for 15 minutes and adjust the $\mathrm{pH}$ of the soln to $5.0 \pm 0.2 \mathrm{pH}$ units with $0.5 \mathrm{M}$ acetic acid.

Keep track of the volume of acetic acid added. DO NOT add more than $4 \mathrm{ml}$ of acetic acjd per gram of sample.

2. Agitate the sample for 15 minutes and adjust the $\mathrm{pH}$ to $5.0 \pm 0.2$ with $0.5 \mathrm{M}$ acetic acid.

3. Agitate the sample for 15 minutes and check the $\mathrm{pH}$. If the $\mathrm{pH}$ change of the soln i.s greater than $0.5 \mathrm{pH}$ units, repeat step 2 . If the $\mathrm{pH}$ change is $<0.5 \mathrm{pH}$ units, adjust the $\mathrm{pH}$ to $5.0 \pm 0.2$ units and agitate the sample for 30 minutes. Continue chēcking and adjusting the $\mathrm{pH}$ of the sample for six hours or until $4.0 \mathrm{ml}$ of $0.5 \mathrm{M}$ acetic acid per gram of sample has been added.

4. Continue agitating the sample for a total of 24 hours. If the total volume of acetic acid added is not $4.0 \mathrm{ml}$ per gram of sample continue checking and adjusting the pH of the sample to $5.0+0.2$ units each hour for an additional four hours.

5. Add D̄W until the total volume of solution is $200 \mathrm{ml}$. Let the lids settle from the sample and filter the supernate using $0.45 \mathrm{~m}$ cron filter. Remove $10 \mathrm{ml}$ aliquots of Sa 1 and the blank sample for $\mathrm{Hg}$ analysis. Remove two $10 \mathrm{ml}$ aliquots of $\mathrm{Sa}: 2$ for $\mathrm{Hg}$ analysis.

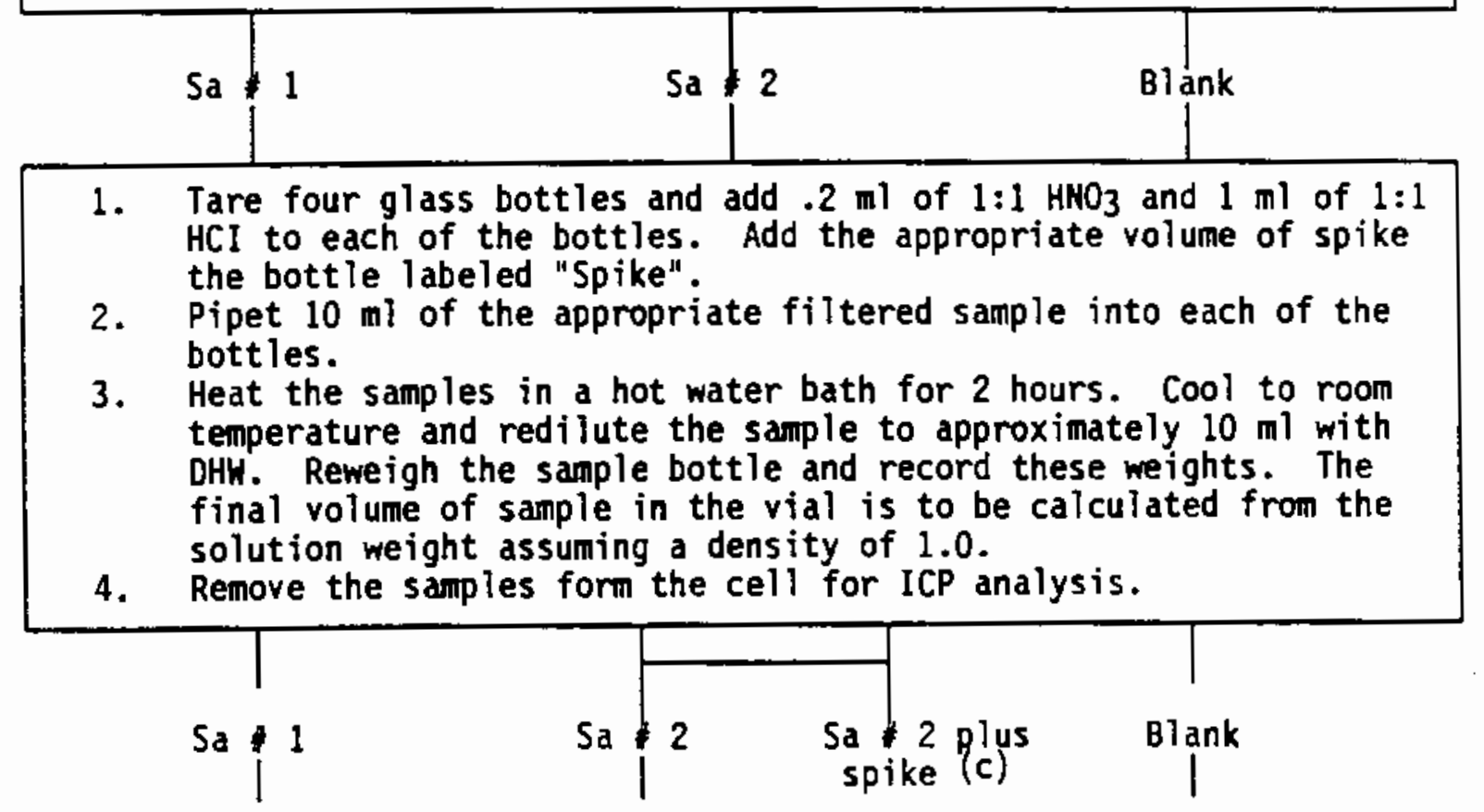


REVISION 0

Approval Date 2-1-89

(c) Spike sample with $0.5 \mathrm{ml}$ of spike containing $100 \mathrm{ug} / \mathrm{ml}$ As, $100 \mathrm{ug} / \mathrm{ml} \mathrm{Ba}$, $20 \mathrm{ug} / \mathrm{ml} \mathrm{Cd}, 100 \mathrm{ug} / \mathrm{ml} \mathrm{Cr}, 100 \mathrm{ug} / \mathrm{ml} \mathrm{Pb}, 20 \mathrm{ug} / \mathrm{ml} \mathrm{Se}, 100 \mathrm{ug} / \mathrm{ml} \mathrm{Ni}$ and $100 \mathrm{ug} / \mathrm{ml} \mathrm{Tl}$. Also add $0.5 \mathrm{ml}$ of $100 \mathrm{ug} / \mathrm{ml} \mathrm{Ag}$ solution. 
REVISION 0

\section{Acid Digestion}

Approval Date 2-1-89

Figure 5 outlines the acid digestion procedure. The procedure for sample preparation in the hot cell is the method from SOW 787 (CLP). The spike levels are determined from previous SST sample analys is and the recommended spike levels given on page $E-10$ of SOW 787 (CLP). The serial dilutions of $5 \times$ wilt be used to determine the accuracy of the major cations such as $\mathrm{Al}, \mathrm{Fe}, \mathrm{Mn}$, $\mathrm{Ni}$, and $\mathrm{Na}$. Silicon will not be spiked since the results have no significance in an acid digested solution. The filter from the acid digested sample will be saved and the acid insoluble portion of the sample will be fused and analyzed on the ICP.

\section{Mercury Analysis}

The method for mercury analysis is outlined on Figure 6 . The sample digestion for mercury analysis is done in the hot cell. After the sample digestion, a preliminary separation of mercury is done in the hot cell by reducing the mercury with stannous chloride and the elemental mercury vapor is trapped into a mercury scrub media of $0.1 \mathrm{M} \mathrm{KMnO} 4$ in $58 \mathrm{H}_{2} \mathrm{SO}_{4}$. After trapping the mercury in the scrub media, the solution is removed from the hot cell and the mercury analysis completed using the cold vapor technique using a Perkin-Elmer AA unit. If the duplicate samples agree within $\pm 20 \%$, a third sample will be spiked with a suitable aliquot of mercury and añalyzed. If the duplicate samples do not agree within $\pm 20 \%$, we must ascertain whether the discrepancy in duplicate samples is from sample nonhomogeneity or some unknown matrix interference in the sample.

\section{Total Cyanide}

The total cyanide method is outlined on Figure 7 . The analyses are performed on duplicate 2 gram samples using the EPA distillation method 9010 . Since we know all SST samples will contain both nitrate and nitrite ions, sulfamic acid will be added to the distillation flask prior to the addition of sulfuric acid. If the duplicate samples agree within $\pm 20 \%$, a third sample will be analyzed using an appropriate spike concentration. If the duplicate samples do not agree within the specified values (SOH 787 page E-11), one would suspect a matrix problem.

\section{Fusion Procedure/Radionuclides}

The $\mathrm{KOH}$ fusion outlined on Figure 8 will be used to dissolve the sample for radiochemical analyses. The radiochemical isotopes measured and the methods of analyses are listed on Table 1 . The objectives of this test are (1) Oetermine if the listed nonroutine and/or environmental radiochemical methods can be used to analyze SST samples, and (2) Gather information relevant to the use of radionuclide ratioing and parent-daughter relationships for estimation of radionuclides within samples. 


\section{FIGURE 5}

\section{SINGLE SHELL TANK \\ Acid Digestion \\ per SOW 787 page $D-4$}

Weigh four 1.0 to $1.5 \pm 0.001 \mathrm{~g}$ samples and place in $250^{-} \mathrm{ml}$ beakers

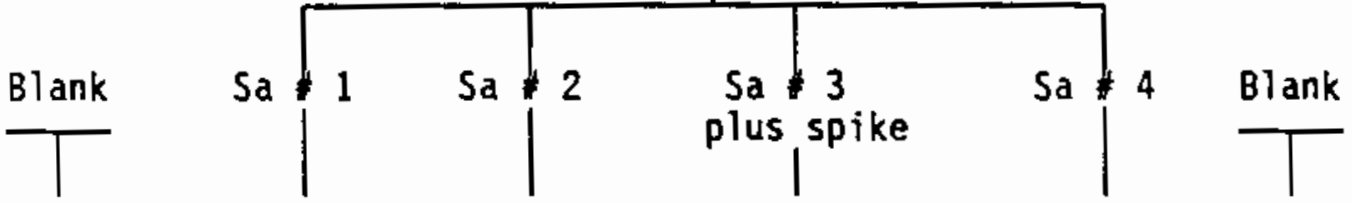

1. Add $10 \mathrm{ml} 1: 1 \mathrm{HNO}_{3}$ to each beaker and heat for 30 minutes.

2. Cool and add $3 \mathrm{ml}$ of $30 \% \mathrm{H}_{2} \mathrm{O}_{2}$ and heat soln until reaction subsides.

3. Add an additional $1 \mathrm{ml}$ portion of $\mathrm{H}_{2} \mathrm{O}_{2}$ and heat until reaction subsides.

4. Repeat step 3 until there is no vigorous reaction or observabie sample change. DO NOT add more than a total of $10 \mathrm{ml} \mathrm{H}_{2} \mathrm{O}_{2}$.

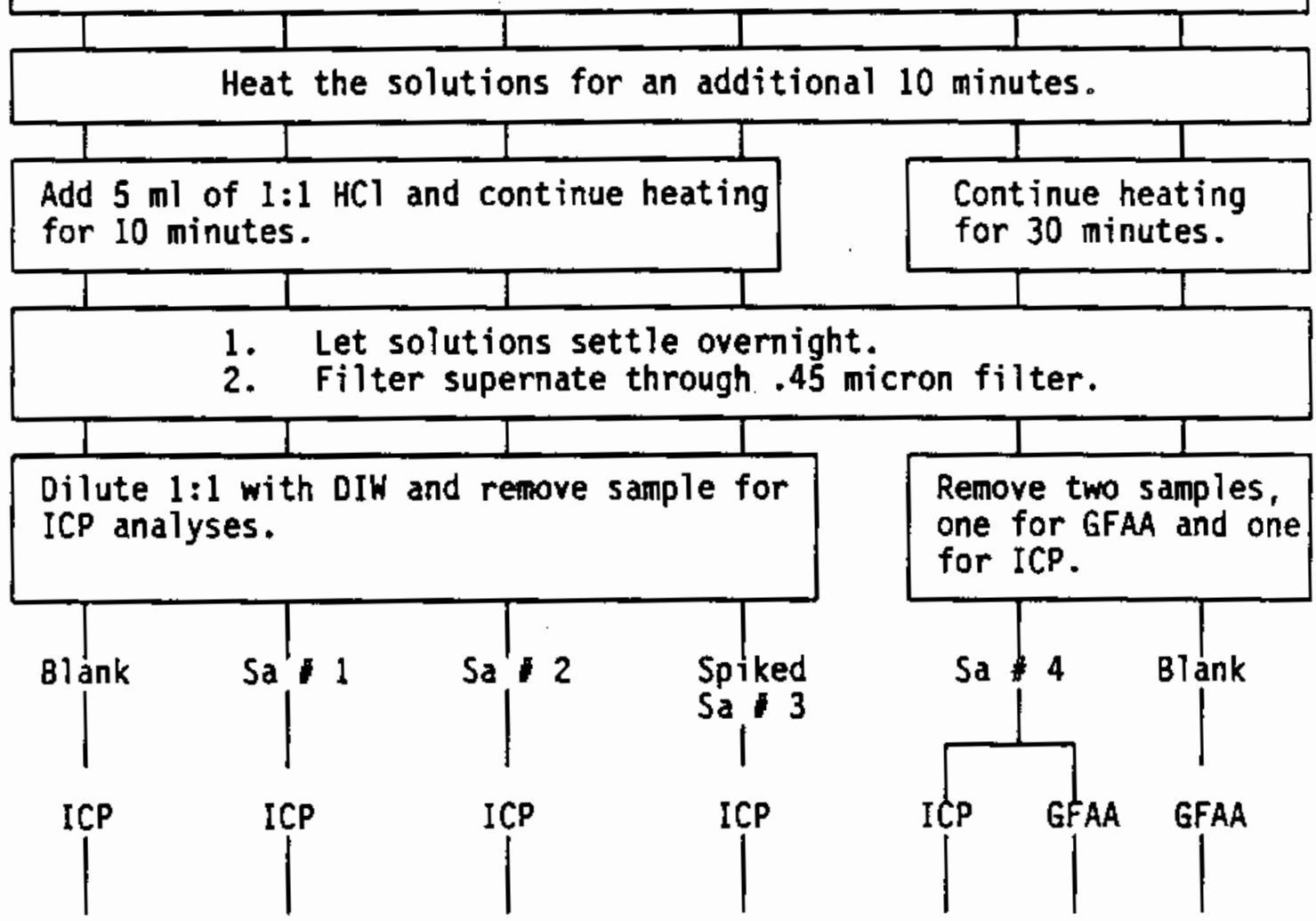

Spike to contain 20 ug Ba, 5 ug $\mathrm{Cd}, 100$ ug $\mathrm{Ca}, 100$ ug $\mathrm{Cr}, 5$ ug $\mathrm{Co}, 50$ ug $\mathrm{Pb}$, 20 ug $\mathrm{Mg}, 100$ ug $\mathrm{K}, 10$ ug $\mathrm{Sr}, 10 \mathrm{ug} \mathrm{Zr}, 10$ ug $\mathrm{Cu}, 5$ ug Sb, 20 ug As,.5 ug $B e, 20 \mathrm{ug} T l, 5 \mathrm{ug} V$, and 5 ug $\mathrm{Zn}$ per $10 \mathrm{ml}$ of sample. A second spike to contain 100 ug $P$ and 5 ug $\mathrm{Ag}$ per $10 \mathrm{ml}$ of sample 
REVISION 0

FIGURE 6

\section{SINGLE SHELL TANK}

Mercury Analyses by Cold Vapor Technique

per SOW 787 modified method 245.5
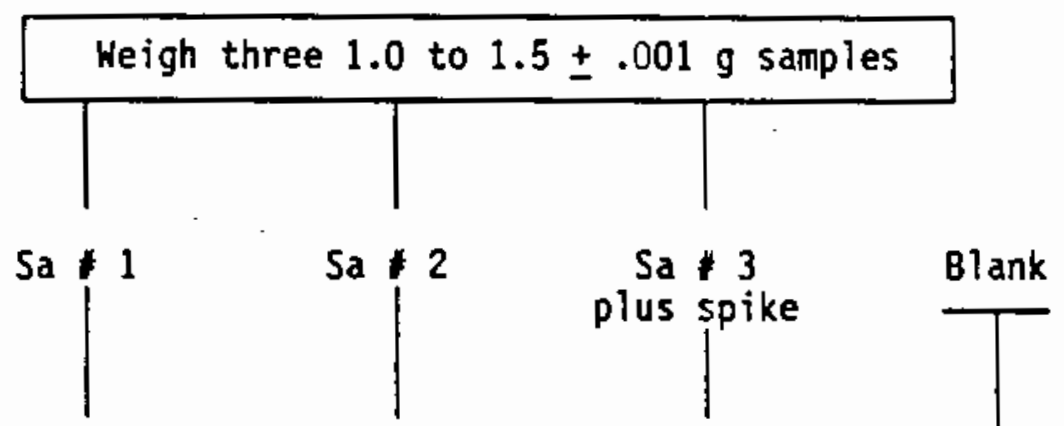

Perform sample digestion as per SOW 787 method 245.5. Using a $250 \mathrm{ml}$ erlenmeyer flask containing a mercury scrub media of $0.1 \mathrm{M} \mathrm{KMnO}_{4}$ in 5\% $\mathrm{H}_{2} \mathrm{SO}_{4}$, reduce the mercury in the sample with a stannous chloride solution and trap the mercury in the scrub media.

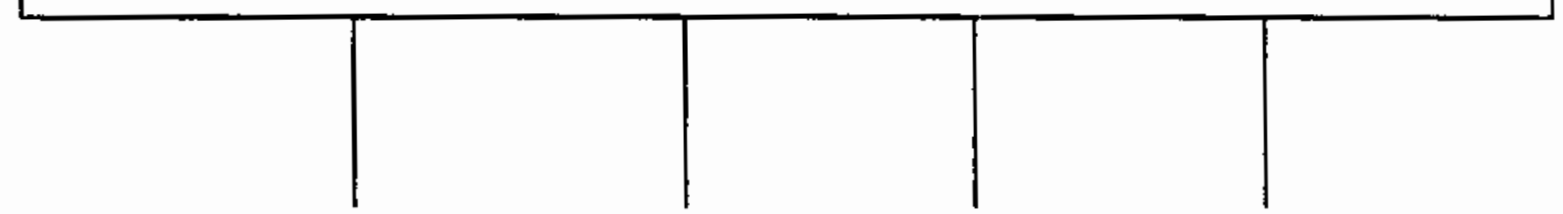

Remove the scrub media from the hot cell and determine the mercury on a suitable aliquot of the scrub media using the cold vapor mercury technique.

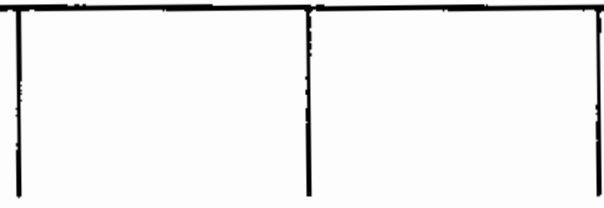

If the duplicate samples are reproducible within $+20 \%$, spike sample Sa $\$ 3$ with a suitable aliquot of mercury and anaTyze. 


\section{FIGURE 7}

SINGLE SHELL TANK

Total Cyanide in Sediment per EPA Method 9010 and CLP Method 335.2
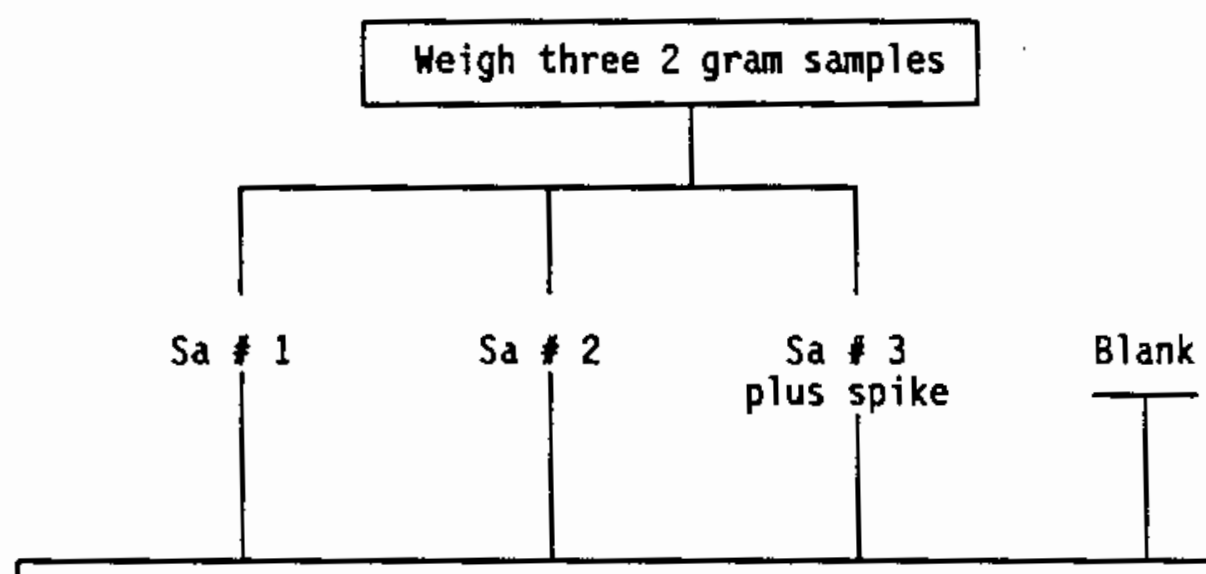

Perform the distillation procedure as outlined in EPA method 9010 . add sulfamic acid to the sample since all SST samples will contain nitrates and nitrites. Remove the $\mathrm{NaOH}$ scrub solution from the hot cell and determined the $\mathrm{CN}$ spectrophotometrically using the Hach it regents. If the duplicate samples agree within $+20 \%$, spike the third sample with a suitable aliquot of cyanide and analyzed.

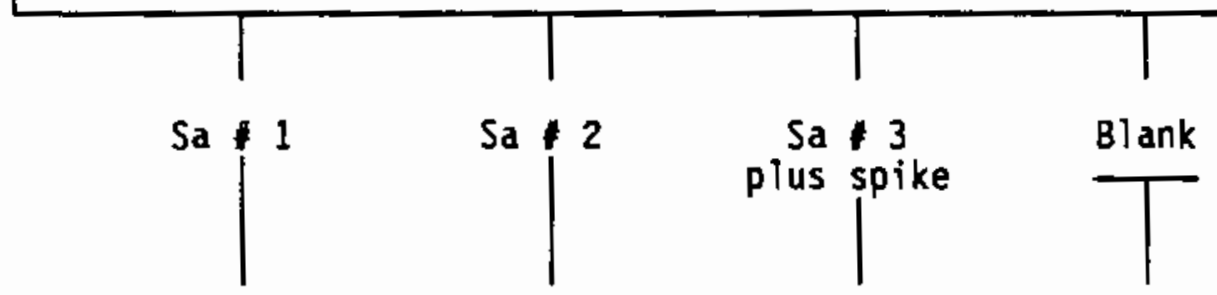




\section{FIGURE 8}

REVISION 0

Approval Date 2-1-89.

SINGLE SHELL TANK

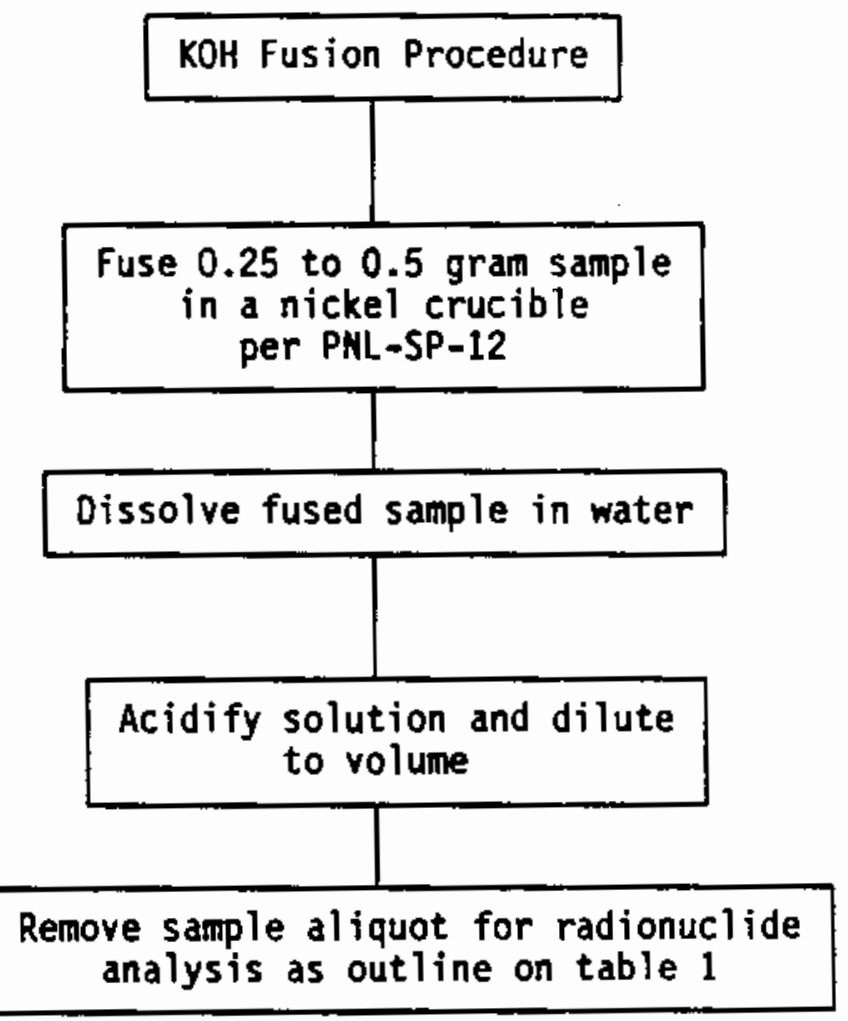


Table 1

RADIOCHEMICAL MEASUREMENTS AND METHODS

\begin{tabular}{|c|c|c|}
\hline Item & Isotope & Procedure \\
\hline 1. & $227_{\mathrm{AC}}$ & PNL-Ac-01 \\
\hline 2. & $\begin{array}{l}241 \mathrm{Am} \\
242 \mathrm{Am} \\
243 \mathrm{Am}\end{array}$ & $\begin{array}{l}\text { * May require mass } \\
\text { spectrometer } \\
\text { analys is }\end{array}$ \\
\hline 3. & $242 \mathrm{~cm}$ & Included in Item 2 \\
\hline 4. & $\begin{array}{l}135 \mathrm{Cs} \\
137 \mathrm{Cs}\end{array}$ & $\begin{array}{l}\text { HTA-4-9 } \\
\text { HTA-4-40 } \\
3-30.6\end{array}$ \\
\hline 5. & $\begin{array}{l}59 \mathrm{Ni} \\
63 \mathrm{Ni}\end{array}$ & PNL-Ni-01 \\
\hline 6. & $94_{N b}$ & PHL-Nb-01 \\
\hline 7. & $231 \mathrm{~Pa}$ & PNL $-P a-01$ \\
\hline 8. & $210 \mathrm{pb}$ & $\begin{array}{l}\text { RSD-51-DIS6 } \\
\text { RSD-51-DIS8 }\end{array}$ \\
\hline 9. & $210 \mathrm{po}_{0}$ & RSD-51-DIS8 \\
\hline 10. & $\begin{array}{l}238 \mathrm{pu} \\
239 \mathrm{pu} \\
240 \mathrm{pu} \\
242 \mathrm{pu}\end{array}$ & $\begin{array}{l}\text { HTA-4-15 } \\
2-30.5 \\
\text { HTA-4-22 } \\
\text { HTA-4-5 and/or }-6\end{array}$ \\
\hline 11. & $\begin{array}{l}226 \mathrm{Ra} \\
228 \mathrm{Ra}\end{array}$ & RSD-51-DEQ-4 \\
\hline 12. & ${ }^{79} \mathrm{Se}$ & HTA-4-18 or $7-40.15$ \\
\hline 13. & $151_{\mathrm{Sm}}$ & PNL-Sm-01 \\
\hline 14. & $\begin{array}{l}229 \mathrm{Th} \\
230 \mathrm{Th} \\
232 \mathrm{Th}\end{array}$ & RSD-51-0EQ-3 \\
\hline
\end{tabular}


REVISION 0

Approval Date 2-i-89

Table 1(continued)

15.

$\begin{array}{ll}233 \mathrm{U} & \text { HTA-4-16 } \\ 234 \mathrm{U} & 2-30.6 \\ 235 \mathrm{U} & \text { HTA-4-36 } \\ 236 \mathrm{U} & \\ 238 \mathrm{U} & \end{array}$

16.

$93 z r$

PNL-Zr-01

17.

Total U Tota 1

Included in item 15

Included in item 4 and 10 
REVISION 0

Approval Date 2-1-89

\section{Semivolatile Organic}

The analytical method for the analysis of semivolatile organic is outlined on Figure 9. The solvent extraction of the sample with methylene chloride will be performed in the hot cell. The organic phase is then removed from the cell and the drying and concentration steps will be done in an open faced hood. Again, the primary purpose of this test is to gain additional experience with the analysis on SST matrices. A portion of the sample will be saved to evaluate the screening method on the gas chromatograph/flame ionization detector (GC/FID) at a later date.

\section{Normal Paraffin Hydrocarbon}

The nomal paraffin hydrocarbon (NPH) laboratory test will use the excess SST sample (241-C-106) presently in the 325 Building hot cell. The flowsheet for this experiment is shown on Figure 10. A slurry will be prepared in the hot cell by mixing the SST sample with the supernate from the 102-AX tank. This slurry will be contacted with an equal volume of NPH and the mixture stirred for 48 hours. The phases will be separated.

The NPH phase analyzed for total alpha, total beta, and a GEA. A portion of the NPH will be leached with water for the analysis of anions by IC. Another portion of NPH will be extracted with $1 \mathrm{MHNO} 3$ and analyzed for cations. If the volume of separated NPH is insufficient for a water and an acid leach, the NPH will be extracted with OIW and the aqueous layer removed. The same $\mathrm{NPH}$ phase will then be extracted with $1 \mathrm{M} \mathrm{HNO} 3$ and both the aqueous sample and the $1 \mathrm{MHNO}_{3}$ analyzed by ICP.

The objective of this experiment is to determine if the radionuclides, anions, and cations are NPH soluble. 


\section{FIGURE 9}

SIMGLE SHELL TANK

Semivolatile Organic Method per SOW 787 Section D-2/SV

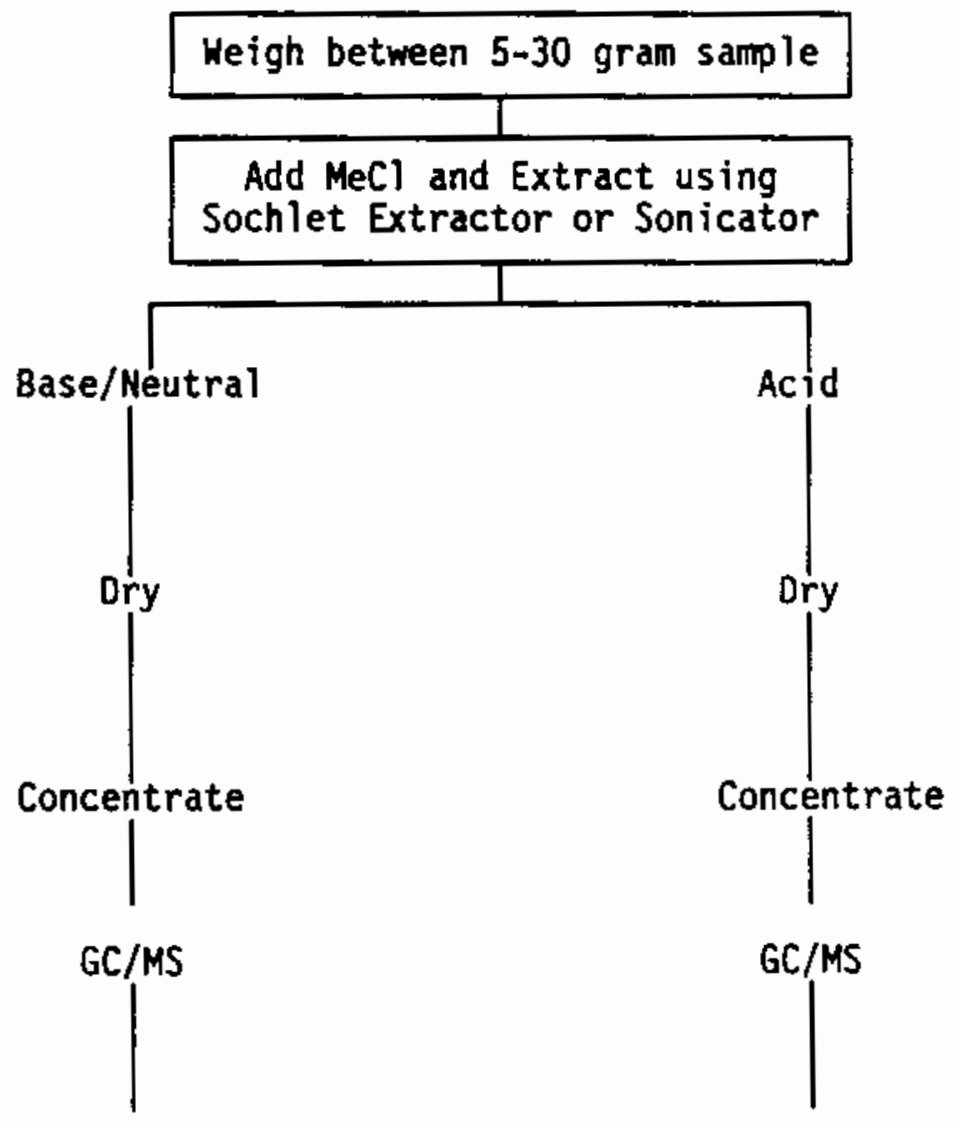

A portion of the sample will be savei for screening analyses at a later date. 


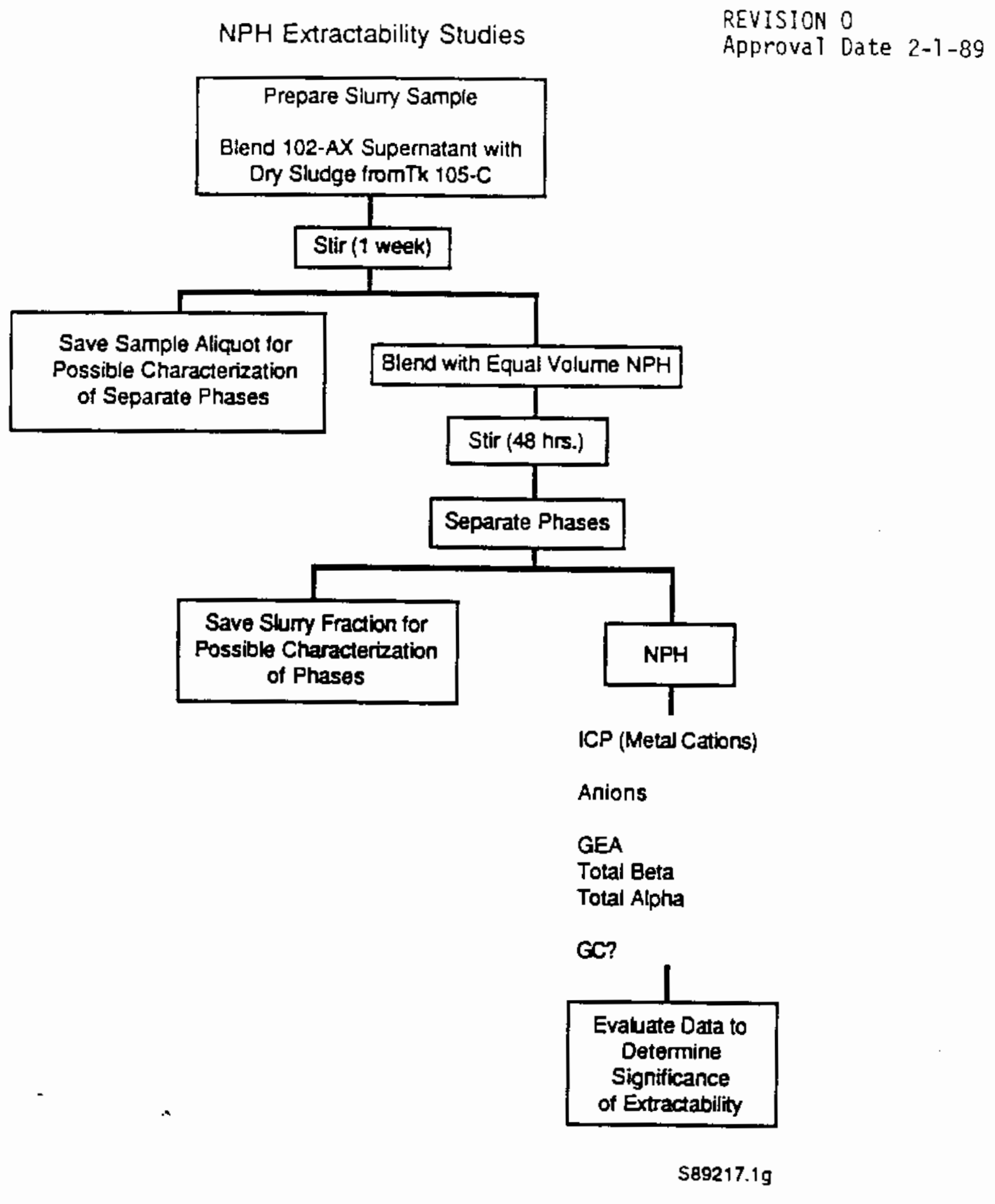

Figure 10 
REVISION 0

Approval Date 2-1-89

\section{PRODUCTS}

The products of this work are the final report and associated data packages and the residual archive samples from WHC and remaining quantities of derivative archive samples. Disposition of the physical archive materials will be as described in the Section VI "Test Program Perquisites and Requirements". The content of the final report is given next.

The report will be structured in two parts.

Part 1 will be a description of results and their significance covering the following four items and referencing the supporting data from the data packages. The four items are: (1) State results, identify problem areas and describe what actions are needed to solve the problems; (2) Radiological exposure data showing time and exposure for each step of a procedure; (3) Significance of field changes made and the relevant procedures, and (4) Radiochemical and radioisotope values which will be used in the Alternative Techniques Task (WBS 8970) for comparison with TRAC data.

Part 2 will encompass all the backup information and data referenced in the first part. These data include the (1) Data Package for each method and the inputs to Alternative Techniques Task, (2) All data, including duplicate and serial dilutions and spike recoveries; and (3) copies of draft procedures not previously transmitted to WHC.

V. PRINCIPAL INVESTIGATOR

The Principal Investigator is FT Hara.

VI. TEST PROGRAM PREREQUISITES \& REQUIREMENTS

\section{Prerequisites}

\section{Personnel Qualifications}

The analysis methods being used to conduct the work are standard methods; personnel have been trained and qualified to perform these methods. No special additional training is needed.

\section{Safety}

The operations to be conducted during the work are standard analytical chemistry methods for wich no unusual safety issues have been identified. The handling of radioactive samples will be controlled by the relevant radiation work permits and monitored by RPT. 
REVISION 0

Approval Date 2-1-89

M\&TE

Analysis procedures contain the requirements and practices for performing calibration and for standardization of instruments. Instrumentation will have calibration stickers for items where calibration is required. The requirements for using calibrated instrumentation are described in the analytical procedures. Documentation for standards and calibration verification solutions are out ined in QA Plan, HTC-033, Rev 1.

\section{Material Identification \& Pretest Verifications}

Sample control and identification is in accordance with QA Plan WTC -033 , Rev 1. Verification of condition of instrumentation and measuring systems is described in the analytical procedures. An instruction on Chain of Custody and appropriate format will be developed and implemented.

\section{Requirements}

\section{Expected Results/Acceptance Criteria}

The purpose of the analysis work is qualitative and quantitative characterization to establish composition rather than to determine acceptability to some criteria. Results of the analysis work will also demonstrate that the available techniques and associated field changes will provide accurate and reproducible results.

Results will provide two types of information. First, analysis will quantify the EPA targeted inorganic and organic constituents SST samples. Second, radiochemical and radioisotope analyses will be used to better understand the ability of TRAC in predicting the radiochemical inventories of the SSTs.

Criteria for acceptability of the characterization data will be determined by the reproducibility of the duplicate analyses, serial dilutions and spike samples for organic and inorganic analyses. The organic and inorganic analyses will be done as outlined in the EPA (SH 846) and/or CLP (SOW 787) methods.

Data analyses and data reduction practices are outlined in the methods of analyses used.

\section{Documentation \& Data Package Preparation}

General documentation will be identified in the records index for task 8930. The principal investigator will define the specific data gathering processes to be used for each method and appropriate format. This data gathering feeds into the data package preparation. 
REVISION 0

Approval Date $2-1-89$

Radiological exposure data will be documented for each procedure used on samples. Each step in each procedure will be evaluated and results documented on radiological exposure data sheet. These data sheets will be accumulated for each procedure. Precautions to limit/control background radiation for incell measurements will be described.

The radiological exposure data sheets will contain the following infomation: Origin of aliquot, name of analyst, Date, volume of aliquot, exposure levels at contact and 1 meter, description of operation, time started and time completed.

Data packages will be individually collated and reviewed for content and reproducibility in accordance with PHL-SA-30. Each data package will be signed by the Principal Investigator and Evaluator. PNL-SA-30 does not cover all the points for a data package for this project. An instruction for preparation of data packages will be prepared and implemented by the Principal Investigator to supplement PNL-SA-30.

Oata packages will contain the following: Results of work including problem areas and proposed solutions; procedures used will be listed and any field changes described; radiological exposure information showing time and exposure data; copies of draft procedures not previously transmitted to WHC, and all raw data. Raw data includes duplicates, serial dilutions and spike recovery, printouts, etc. Where data bases were developed they will be shown in hardcopy and a working disk provided.

Hazardous materials and waste information generated in the HMA task will be organized and retained for use in follow-on work with SST samples.

\section{Change Control and Test Modifications}

Changes to the technical content of test planning will require review and approval equivalent to that of the original; field changes during work will be documented and discussed with the project manager and included in the final data package. Changes in scope, cost or schedule require the approval of the line manager, project manager and customer.

\section{Data Review \& Evaluation}

Data review and evaluation will use a three stage process. First, the person(s) doing analysis will obtain the verification of their work by the Principal Investigator on a regular basis. Regular means with each set of analyses of each sample; review will be documented by initials and date in the appropriate place.

Second, Principal Investigator will review results in a systematic way to ensure that results are meaningful. This review will be used to detemine when additional samples are to be run and/or when progress is deviating from expectations. 
REVISION 0

Approval Date 2-7-89

Third, the Independent Evaluator, per PAP-1101, will be appointed by the project manager and performs the following: (1) Independent review per PNLMA-70; (2) Concurs in the data packages, and (3) Concurs in the final report confining that the results are consistent with the raw data, data reduction techniques were valid and the conclusions are supported by the data.

\section{Instructions and Procedures}

Analysis methods to be used are described in the test description. PNL Technical Procedures numbered PNL-SA-21 through $-\$ A-50$ are key routine procedures which will be followed during the work. These, in conjunction with the specific methods, provide additional administrative control ensures the quality of the data.

Procedures used, including field changes and test instructions, shall be adequate for a person familiar with the equipment and techniques to reproduce the data.

\section{Hazardous Materials Management}

The processes used will be evaluated for both personnel hazards and waste disposal and environmental requirements. The identification of chemicals and materials to be used and/or generated provide the basis for specific decisions. These data are used to identify any unique safety, environmental or waste issues and to chose between the various options for resolving issues. An example of an important issue would be handling excess input or derivative archive materials, waste streams treatment \& disposal.

Characteristics and volume(s) of materials used /generated are necessary for the development of a waste disposal plan, environmental compliance evaluation and decisions on need for MSDSs and hazards communication.

The waste disposal plan preparation and content are described below under "Requi rements".

The archive samples, provided by Hestinghouse Hanford Company; are radioactive mixed waste samples for characterization by PNL. Radioactive mixed waste materials must be controlled. Dilutions of these archive materials will be made to use as starting points for various analyses; these derivative archive samples will be identified as such and included in the discussions with HHC regarding disposition.

\section{Waste Disposal Plan}

A waste disposal plan will be prepared for the work and will be reviewed with Haste Management/Environmental Control section of Laboratory Safety. Preparation will be done in conjunction with 325 hot cell facility personnel. No disposal of liquids to the Hot cell radioactive liquid waste sewer will be done prior to review and acceptance of the planning by Laboratory Safety. 
Planning will be based on identifed waste streans from each process step for each method, the composition and volumes using PNL-MA-8 for guidance and assistance from Laboratory Safety staff. This information is provided to Materials and Chemical Sciences Center Operations Manager for use in developing and updating waste projections.

Hazardous materials and waste information generated in the HMM task will be organized and retained for use in follow-on work with SST sampies. 
PNL-7258 Rev. I

UC -721

\section{DISTRIBUTION}

No. of

Copies

OFFSITE

2 Office of Scientific and

Technical Information

F. T. Hara

WVNS Company

Rock Springs Road

West Valley, NY 14171-0191

\section{ONSITE}

3 DOE Richland Operations

M. J. Anthony, R4-04

R. E. Gerton, A5-21

R. D. Izatt, A5-19

56 Westinghouse Hanford Company

T. S. Bohling, H4-22

D. R. Bratze1, T6-50

P. K. Clark, A5-21

A. J. Diliberto (50), R2-12

L. Jensen, T6-18

L. M. Sasaki, R2-12

W. I. Winters, T6-50
No. of

Copies

27 Pacific Northwest Laboratory

R. T. Hallen, K2-12

D. K. Hilliard, K2-12

T. E. Jones, P7-25

J. H. Kaye, P7-22

W. W. Laity, K2-15

J. M. Latkovich, P7-22

A. J. Schmidt (2), K2-12

L. J. Sealock, Jr., K2-10

R. T. Steele, P7-22

R. W. Stromatt, $P 7-22$

D. L. Thomas, K2-12

K. M. Tominey, K6-25

M. W. Urie, $P 7-22$

H. H. Van Tuyl, P7-22

R. S. Wegeng (5), $K 6-31$

W. C. Weimer, P7-22

Publishing Coordination

Technical Report Files (5) 

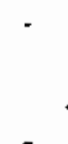

-

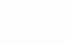

$\therefore$

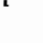

$\cdot$.
$-\quad 2$

.

. 